ISABELLI DE OLIVEIRA MARTINS

\title{
INFLUENCIA DOS HORMÔNIOS SEXUAIS FEMININOS NO REMODELAMENTO E NA REATIVIDADE DAS VIAS AÉREAS EM MODELO MURINO DE INFLAMAÇÃO PULMONAR ALÉRGICA CRÔNICA
}

Tese apresentada ao Programa de PósGraduação em Farmacologia do Instituto de Ciências Biomédicas da Universidade de São Paulo, para obtenção do Título de Doutor em Ciências. 
ISABELLI DE OLIVEIRA MARTINS

\section{INFLUENCIA DOS HORMÔNIOS SEXUAIS FEMININOS NO REMODELAMENTO E NA REATIVIDADE DAS VIAS AÉREAS EM MODELO MURINO DE INFLAMAÇÃO PULMONAR ALÉRGICA CRÔNICA}

Tese apresentada ao Programa de Pós-Graduação do Instituto de Ciências Biomédicas da Universidade de São Paulo, para obtenção do Título de Doutor em Ciências.

Área de Concentração: Farmacologia

Orientador: Prof. Dr.Wothan Tavares de Lima

Versão corrigida. A versão original eletrônica encontra-se disponível tanto na Biblioteca do ICB quanto na Biblioteca Digital de Teses e Dissertações da USP (BDTD). 
DADOS DE CATALOGAÇÃO NA PUBLICAÇÃO (CIP)

Serviço de Biblioteca e Informação Biomédica do

Instituto de Ciências Biomédicas da Universidade de São Paulo

reprodução não autorizada pelo autor

Martins, Isabelli de Oliveira.

Influência dos hormônios sexuais femininos no remodelamento e na reatividade das vias aéreas em modelo murino de inflamação pulmonar crônica / Isabelli de Oliveira Martins. -- São Paulo, 2013.

Orientador: Prof. Dr. Wothan Tavares de Lima.

(Doutorado) - Universidade de São Paulo. Instituto de Ciências Biomédicas. Departamento de Farmacologia. Área de concentração: Farmacologia. Linha de pesquisa: Fisiopatologia da inflamação experimental pulmonar e sistêmica.

Versão do título para o inglês: Influence of female sex hormones on airway remodeling and responsiveness in a murine model of lung inflammation.

1. Reatividade vias aéreas 2. Remodelamento vias aéreas 3. Inflamação pulmonar 4. Asma experimental 5. Hormônios sexuais femininos I. Lima, Prof. Dr. Wothan Tavares de II. Universidade de São Paulo. Instituto de Ciências Biomédicas. Programa de PósGraduação em FarmacologiaUniversidade de São Paulo. Instituto de Ciências Biomédicas. Programa de Pós-Graduação em Farmacologia III. Título. 


\section{UNIVERSIDADE DE SÃO PAULO \\ INSTITUTO DE CIÊNCIAS BIOMÉDICAS}

Candidato(a): $\quad$ Isabelli de Oliveira Martins.

Título da Tese: Influência dos hormônios sexuais femininos no remodelamento e na reatividade das vias aéreas em modelo murino de inflamação pulmonar crônica.

Orientador(a): $\quad$ Prof. Dr. Wothan Tavares de Lima.

A Comissão Julgadora dos trabalhos de Defesa da Tese de Doutorado, em sessão pública realizada a considerou
( ) Aprovado(a)
( ) Reprovado(a)

\begin{tabular}{|c|c|}
\hline Examinador(a): & $\begin{array}{l}\text { Assinatura: } \\
\text { Nome: ........ } \\
\text { Instituição: }\end{array}$ \\
\hline Examinador(a): & $\begin{array}{l}\text { Assinatura: } \\
\text { Nome: ........ } \\
\text { Instituição: }\end{array}$ \\
\hline Examinador(a): & $\begin{array}{l}\text { Assinatura: } \\
\text { Nome: ......... } \\
\text { Instituição: }\end{array}$ \\
\hline Examinador(a): & $\begin{array}{l}\text { Assinatura: } \\
\text { Nome: ......... } \\
\text { Instituição: . }\end{array}$ \\
\hline Presidente: & $\begin{array}{l}\text { Assinatura: } \\
\text { Nome: ......... } \\
\text { Instituição: . }\end{array}$ \\
\hline
\end{tabular}




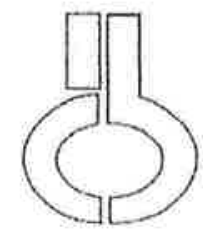

UINIVERSIDADE DE SÄO PAULO IINSTITUTO DE CIÉNCIAS BIOMÉDICAS

Cidade Universltaria "Armando de Salles Ollvelra"

Av. Praf. Lineu Prestes, 2d15 - CEP. 05508-000 Säo Paulo, SP - Brasil

Telefone:(55) (011) 3091.7733 - telefax : (55) (011) 2091.7438

e-\{nall: cep(8),

\section{Certificado}

Certificamos que o protocolo registrado sob $n^{\prime \prime} 101$ nas fls. 49 do livro 2 para uso de animais em experimentação, sob a responsabilidade de Wothan Tavares de Lima Coordenador(a) da Linha de pesquisa "Caracterzação do envoluimento dos hormóntos sexuats femintnos em modelo murtno de asma crônica" do qual participou(aram) o(s) alunos Clartana Rodrtgues Soares, Isabelli Martins e a pesquisadora Ana Paula Ligeiro de Oliveira, está de acordo com os Principios Éticos de Experimentação Animal adotado pelo Colégio Brasileiro de Experimentação Animal (COBEA) e foi aprovado pela COMISSĀO DE ETICA EM EXPERIMENTACĀO ANIMAL (CEEA) em 22.10.2007.

São Paulo, 23 de outubro de 2007.

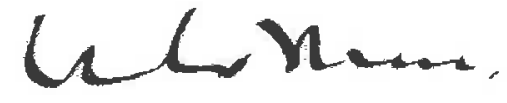

Prof. Dr. WOTHAN TAVARES DE LIMA

Coordenador CEEA - ICB/USP

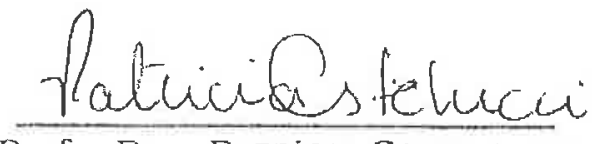

Profa. Dra. PATRICIA CASTElUCCI

Secretăria CEEA - ICB/USP 
A Deus toda honra e toda glória sempre. 
À tia Ruth, pelo amor maior que me oferece. 


\section{AGRADECIMENTOS}

A Deus, por me permitir chegar até aqui.

À tia Ruth, pelo grande amor, e a qual sem o suporte eu não poderia ter ingressado.

A minha família, pelo incentivo perpétuo.

Ao meu orientador, Professor Dr. Wothan Tavares de Lima, por me permitir fazer parte da equipe mesmo com tempo limitado e pelos preciosos ensinamentos.

Aos amigos de laboratório: João Gimenez, Fernando Coelho, Clariana Rodrigues, Beatriz Golega, Luana Vitoretti, Evelyn Fantozzi, Jonatas Bertonni, Helory Vanny, Ana Paula Ligeiro, Adriana Lino, Alexandre Learth e Ana Cristina Fallopa pela amizade, enorme ajuda e colaboração no trabalho.

À Zilma Lucia, que me ensinou a fazer ovariectomia!

Aos professores Ricardo Oliveira e Henrique Moriya pelo suporte científico e pela inspiração!

À Juliana pela paciência, pelas muitas horas de técnica ao computador e, sobretudo, pelo apoio e amizade.

À Universidade de São Paulo pela excelência e pela infinidade de possibilidades que nos apresenta.

A todos que de alguma maneira foram importantes para a execução desse trabalho, meus sinceros agradecimentos. 
"Cada sonho que você deixa para trás, é um pedaço do seu futuro que deixa de existir." 


\section{RESUMO}

MARTINS, I. O. Influencia dos hormônios sexuais femininos no remodelamento e na reatividade das vias aéreas em modelo murino de inflamação pulmonar alérgica crônica. 2013. 127 f. Tese (Doutorado em Farmacologia) - Instituto de Ciências Biomédicas, Universidade de São Paulo, São Paulo, 2013.

A inflamação crônica que caracteriza a asma conduz a um remodelamento progressivo das vias aéreas ao longo da evolução da doença. O remodelamento é evidenciado pela deposição de colágeno na matriz extracelular, hiperplasia de células produtoras de muco, hiperplasia de musculatura lisa peribronquiolar e hipertrofia epitelial. O remodelamento é reconhecido como um dos fatores mais importantes no aumento da reatividade das vias aéreas em pacientes asmáticos. Evidencias epidemiológicas revelam que os hormônios sexuais femininos (HSFs) exercem um papel importante na modulação do processo inflamatório e nas alterações na função pulmonar que caracterizam a asma. Neste trabalho, investigamos a influência dos HSFs no remodelamento e na reatividade brônquica mediados pela inflamação alérgica pulmonar crônica. Camundongos fêmeas $\mathrm{C} 57 \mathrm{Bl} / 6$ foram submetidas à ovariectomia bilateral (OVx), sensibilizadas com ovoalbumina (OVA) após 7 dias (OVA 1mg/ml sc) com reforço no $14^{\circ}$ dia após a OVx. No $21^{\circ}$ dia pós ovariectomia iniciaram-se desafios inalatórios com OVA (aerosol, 1\%, $15 \mathrm{~min}$ ) três vezes por semana durante três semanas. Passadas $120 \mathrm{~h}$ do último desafio, os animais foram submetidos à eutanásia e a reatividade ex vivo dos anéis de traqueia à metacolina $(\mathrm{MCh})$ foi avaliada pelo sistema de aquisição de dados "Power Lab". Também realizamos avaliações histológicas e quantificação de metaloproteinases (MMPs) no parênquima pulmonar. Para a análise histológica, os tecidos pulmonares foram fixados e corados com Picrussirius e PAS e analisados pelo software Image Pro-Plus. Para quantificação de MMPs foi utilizado o método de zimografia. $\mathrm{O}$ grupo controle consistiu de animais também alérgicos, porém falsamente-operados (grupo sham Ovx Alérgico). A resistência $(\mathrm{R})$ e a elastância $(\mathrm{E})$ totais foram medidas através de ventilador mecânico para pequenos animais FlexiVent ${ }^{\circledR}$ Os resultados foram analisados pelo princípio do modelo unicompartimental. $\mathrm{O}$ grupo $\mathrm{OVx}$-alérgico teve a reatividade traqueal à $\mathrm{MCh}$ e a produção de muco, de colágeno e a quantificação de músculo liso peribronquiolar significativamente reduzida em comparação ao grupo sham-OVx alérgico. O grupo OVx alérgico tratado com estrógeno apresentou aumento de MMP-2 e o grupo OVx alérgico tratado com progesterona apresentou aumento de MMP-9 sugerindo que as MMPs sofrem modulação pelos HSFs. R e E foram respectivamente maior e menor no grupo Sham-OVx alérgico. Nossos dados sugerem que o curso da inflamação pulmonar crônica pode ser modificado pelo ambiente hormonal de maneira que a redução dos HSFs tende a diminuir as alterações teciduais que caracterizam o remodelamento das vias aéreas.

Palavras-chave: Hormônios sexuais femininos. Asma. Inflamação pulmonar. Remodelamento. Reatividade das vias aéreas. Metaloproteinases. Mecânica pulmonar. 


\begin{abstract}
MARTINS, I. O. Influence of female sex hormones on remodeling and responsiveness of airways in a murine model of chronic lung inflammation 2013. $127 \mathrm{p}$. Ph. D. Thesis (Pharmacology) - Instituto de Ciências Biomédicas, Universidade de São Paulo, 2013.

Asthma is a chronic lung inflammatory disease characterized by airway tissue injury and inflammatory cell influx. The chronic inflammation modifies bronchial structure, causing remodeling and increased responsiveness. Remodeling is recognized by fibrosis of subepithelial basement membrane, hypertrophy of bronchial glands, goblet cell hyperplasia and thickening of airway epithelium. Remodeling is one of the most important factors related to the impairment of lungs function. Compelling evidence shows that female sex hormones (HSF) exert a controversial role in inflammation during menses and post-menopausal period. Experimental and clinical evidences shows that HSF can attenuate or maximize inflammatory process in acute allergic lung inflammation. In this study we investigated role of HSF in airway remodeling and tracheal responsiveness in a model of chronic lung inflammation.

Female $\mathrm{C} 57 \mathrm{~B} / 6$ mice were subjected to ovaries removal $(\mathrm{OVx})$ and 7 days later they were OVA-sensitized (OVA $1 \mathrm{mg} / \mathrm{ml} \mathrm{SC}$ ) by subcutaneous route. After 1 week the animals were boosted. After another seven days, OVA-challenge (aerosol, $15 \mathrm{~min}$, OVA 1\%) three times a week during 03 weeks was performed (OVx allergic mice). Elapsed 120h of the last OVAchallenge the mice were euthanized and histological assessment (picrusirius red and PAS staining) was performed to evaluate mucus production, collagen deposition, smooth muscle hyperplasia and airway thickness on small bronchial compartment (analyzed by Image ProPlus" software). Also, contractile response of tracheal rings to methacholine (MCh) was performed in vitro using an organ bath system. Total lung resistance (R) and elastance (E) were measured in anesthetized mice undergoing mechanical ventilation on a FlexiVent computer-controlled piston ventilator in order to derive parameters of respiratory function. Data were analyzed using the single-compartment model. Control group consisted of ShamOVx allergic mice. Measurements of bronchial mucus, collagen and airway smooth muscle were significantly lower after chronic antigen exposure of $\mathrm{OVx}$ mice compared with their Sham OVx- allergic counterparts. OVx allergic mice showed reduced tracheal responsiveness in vitro to MCh (Emax: $3.65 \mathrm{~g}$ ) in comparison to Sham-OVx allergic mice (Emax: $1.6 \mathrm{~g}$ ). Total lung resistance $(\mathrm{R})$ and elastance $(\mathrm{E})$ were higher and lower respectively in Sham-OVx allergic mice.
\end{abstract}

Keywords: Asthma. Female sex hormones. Airway remodeling. Airway responsiveness. Lung inflammation. Metalloproteinases. Lung mechanics. 


\section{LISTA DE FIGURAS}

Figura 1- Representação dos efeitos inflamatórios da asma nas vias aéreas........................... 25

Figura 2- Representação da inflamação crônica das vias aéreas na asma............................... 28

Figura 3- Oscilações hormonais do ciclo sexual feminino humano........................................ 36

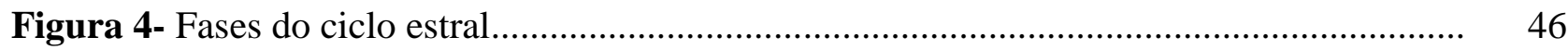

Figura 5- Delineamento do protocolo experimental....................................................... 47

Figura 6- Representação da diminuição luminal dos bronquíolos distais após remodelamento 51

Figura 7- Percentual de muco nas vias aéreas em animais submetidos a 21 desafios alérgicos 56

Figura 8- Percentual de colágeno nas vias aéreas em animais submetidos a 21 desafios

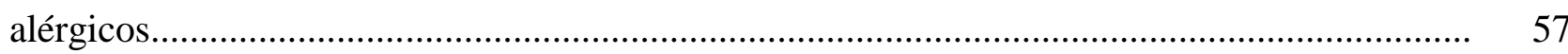

Figura 9- Percentual de muco nas vias aéreas em animais submetidos a 9 desafios alérgicos.. 58

Figura 10- Fotomicrografia dos grupos: basal, sham OVx alérgico e OVx alérgico corados com P.A.S.

Figura 11- Percentual de muco nas vias aéreas dos grupos experimentais com 9 desafios alérgicos tratados com HSF.

Figura 12- Fotomicrografia das vias aéreas dos grupos $\mathrm{OVx}$ alérgico+E e $\mathrm{OVx}$ alérgico+P corados com P.A.S. para revelação de muco.

Figura 13- Percentual de colágeno nas vias aéreas em animais submetidos a 9 desafios alérgicos.

Figura 14- Fotomicrografia de bronquíolo distal mal do grupo basal corado com picrussirius red para revelação de colágeno.

Figura 15- Percentual de colágeno nas vias aéreas de animais submetidos a 9 desafios alérgicos e tratados com HSF.

Figura 16- Fotomicrografia das vias aéreas distais dos animais alérgicos coradas com nicrucsirius rod nara revelacão de coláoenn

Figura 17- Percentual de músculo liso nas vias aéreas dos grupos de animais submetidos a 9 desafios alérgicos.

Figura 18- Percentual da área ocupada pelo epitélio nas vias aéreas dos grupos de animais submetidos a 9 desafios alérgicos.

Figura 19- Avaliação morfométrica da diminuição luminal das vias aéreas.

Figura 20- Reatividade dos anéis de traquéia ex vivo frente à estímulo colinérgico do grupo ovariectomiado em relação ao grupo não ovariectomizado e ao falso-operado 
Figura 21- Reatividade dos anéis de traquéia ex vivo frente à estímulo colinérgico de todos os grupos experimentais

Figura 22-Quantificação de MMP-2 no parênquima pulmonar dos grupos de experimentação 71

Figura 23-Quantificação de MMP-9 no parênquima pulmonar dos grupos de experimentação 72

Figura 24- Medida da resistência das vias aéreas....................................................................... 73

Figura 25- Medida da elastância das vias aéreas......................................................................

Figura 26- Medida da resistência das vias aéreas do grupo basal........................................... 75

Figura 27- Medida da elastância das vias aéreas do grupo basal............................................ 75

Figura 28- Medida da resistência das vias aéreas do grupo sham OVx alérgico....................... 76

Figura 29- Medida da elastância das vias aéreas do grupo sham OVx alérgico........................ 76

Figura 30- Medida da resistência das vias aéreas do grupo OVx alérgico............................... 77

Figura 31- Medida da elastância das vias aéreas do grupo OVx alérgico................................ 77

Figura 32- Medida da resistência das vias aéreas do grupo OVx alérgico+E........................... 78

Figura 33- Medida da elastância das vias aéreas do grupo OVx alérgico+E........................... 78

Figura 34- Medida da resistência das vias aéreas do grupo OVx alérgico+P.......................... 79

Figura 35- Medida da elastância das vias aéreas do grupo OVx alérgico+P........................... 79 


\section{LISTA DE ABREVIATURAS E SIGLAS}

*p: interval de confiança estatístico

AMPc: Adenosina monofasfato cíclico

APC: Célula apresentadora de antígeno

ATP: Trifosfato de adenosina

CD4+: Cluster differentiation 4

CD40: Proteína coestimulatória

CD8+: Cluster differentiation 8

CO2: Dióxido de carbono

COD: Coeficiente de determinação

D.O.: Densidade Óptica

DDP: Diferença de potencial

DMEM: Dulbecco's Modified Eagle's Medium

EDTA: Ácido etilenodiamino tetra-acético

eNOS: óxido nítrico sintase endotelial 
EPM: Erro padrão da média

ER: Receptor de estrógeno

Explante: Cultura de tecido pulmonar

FGF: Fibroblast growth factor

$\mathrm{HCl}$ : Ácido clorídrico

HE: Hematoxilina - Eosina

i.m.: intramuscular

i.p.: intraperitoneal

ICAM-1: Moléculas de adesão intracelular tipo 1

IgE: Imunoglobulina $\mathrm{E}$

IGF: Insulin-like growing factor

IL: Interleucina

INF $\gamma$ : Interferon gama

$\mathrm{KCl}$ : Cloreto de potássio

KDa: Kilodaltons

Kg: Kilogramas

LB: Linfócito B 
LBA: Lavado bronco-alveolar

LT: Linfócito T

LTB4: Leucotrieno B4

LV: Lavado vaginal

Mg: Miligramas

MHC: Complexo de histocompatibilidade humano

Mm: Milimolar

MMP: Matrix metalloproteinases

MMP-2: Metaloproteinase de matrix 2

MMP-8: metoproteinase de matrix8

MMP-9: Metaloproteinase de matrix 9

MPO: Mieloperoxidase

$\mathrm{mV}$ : Milivolts

NF-кB: Fator nuclear kappa B

NO: Óxido nítrico

NOS: Óxido nítrico sintase

O2: Oxigenio 
OVx: Ovariectomia

P450: citocromo hepático P450

PAF: Fator ativador de plaquetas

PAS: Ácido periódico de Schiff

PBS: Phosphate buffered saline

PDGF: Pratelet derived growth factor

PEEP: Pressão parcial ao final da expiração

PGE: Prostaglandina

PGE2: Prostraglandina 2

PGF2 $\alpha$ : Prostaglandina F2 alfa

pH: potencial de hidrogênio ionizável

PK3: Proteína kinase 3

PLA: Pratelet Ativating factor

PMN: Polimorfonucleares

ROS: Espécies reativas de oxigênio

s.c.: subcutânea

SDS: Dodecil sulfato de sódio 
SUS: Sistema único de saúde

TGF: Transforming growth factor

Th2: linfócitos tipo "helper” 2

TIMPs: Tissue Inibhitor of matrix metalloproteinases

TNF: Fator de necrose tumoral

TNF- $\alpha$ : Fator de necrose tumoral alfa

UTI: Unidade de Terapia intensiva

VCAM: Molécula de adesão vascular

VEGF: Vascular Endothelial Growth Factor 


\section{SUMÁRIO}

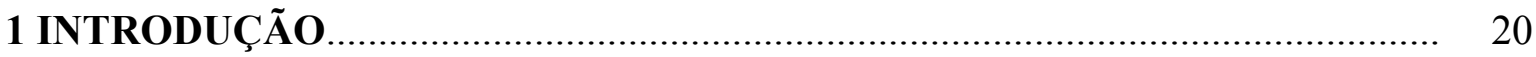

1.1 Conceito, importância e prevalência da asma...................................................... 20

1.2 Patogenia da asma................................................................................... 23

1.3 Cronificação do processo inflamatório crônico e remodelamento na asma........... 27

1.4 Hormônios sexuais femininos e asma ...............................................................

1.5 Hormônios sexuais femininos e 36

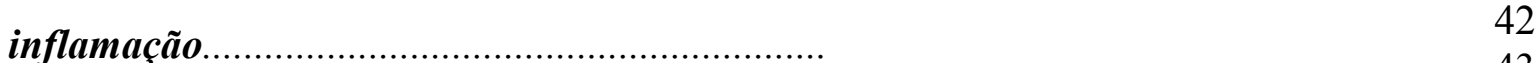

2 JUSTIFICATIVA

3 OBJETIVOS $\quad 44$

4 MATERIAIS E MÉTODOS ........................................................... 44

4.1 Animais....................... 44

4.1 .1 Grupos de estudo.............................................................................

4.1.2 Tratamentos farmacológicos ............................................................................. 45

4.1.3 Ovariectomia ............................................................................................ 45

4.1.4 Validação da ovariectomia .......................................................................... 48

4.1.5 Sensibilização e broncoprovocação in vivo......................................................... 49

4.2 Avaliação do remodelamento das vias aéreas..................................................... 49

4.2.1 Avaliação do colágeno nos bronquiolos distais................................................. $\quad 50$

4.2.2 Avaliação da presença de muco nos bronquiolos distais...................................... 50

4.2.3 Avaliação da camada de músculo liso peribronquiolar......................................

4.2.4 Avaliação da camada de epitélio respiratório das vias aéreas............................. 52

4.2.5 Avaliação morfométrica dos bronquiolos distais............................................. 52

4.3 Estudo ex vivo da traquéia isolada................................................................. 52

4.4 Quantificação de metaloproteinases de matriz................................................... 54

4.5 Avaliação da mecânica pulmonar in vivo......................................................... 55

4.6 Drogas utilizadas ................................................................................... 56

4.7 Análise estatística ......................................................................................... 56

₹ RESULTADOS................................................................................................ 56

.1 Quantificação da massa uterina após a remoção dos ovários................................ 59

5.2 Estabelecimento do protocolo de remodelamento pulmonar.................................. 62

5.3 Efeito da ovariectomia sobre a quantificação de muco nas vias aéreas................ 67

5.4 Efeito da ovariectomia sobre a quantificação de colágeno nas vias aéreas........... 68

5.5 Efeito da ovariectomia sobre a quantificação de músculo liso peribronquiolar.... 69

5.6 Efeito da ovariectomia sobre a quantificação do epitélio das vias aéreas.............. 70

5.7 Efeito da ovariectomia sobre a morfologia das vias aéreas distais.

5.8 Efeito da ovariectomia na reatividade ex vivo de traqueia isolada....................... 71

5.9 Efeito da ovariectomia e dos tratamentos com HSF na quantificação de MMP2 74

e 9 no parênquima pulmonar. 82

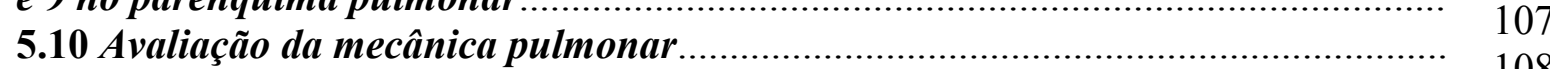

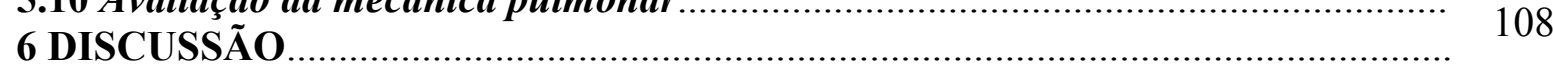

7 CONCLUSÕES.

REFERÊNCIAS. 


\section{INTRODUÇÃO}

\subsection{Conceito, importância e prevalência da asma}

A asma é uma doença inflamatória crônica das vias aéreas inferiores que se apresenta clinicamente através de sintomas recorrentes, relacionados à exposição à alérgenos, substâncias irritantes, infecções, estímulos físicos ou exercícios. Seus principais sintomas são: dispneia, sibilância, tosse seca e sensação de aperto torácico.

Uma característica marcante da asma é a hiper-reatividade brônquica. A hiperreatividade das vias aéreas pode ser conceituada como o fenômeno da reação contrátil exacerbada dos brônquios à determinados estímulos (MEURS; GOSEINS; ZAAGSMA, 2008). A broncoconstricção causa obstrução ao fluxo aéreo, que na asma, é tipicamente reversível (GINA-BRASIL, 2013). A reversão dos sintomas pode ocorrer tanto espontaneamente quanto após a administração de drogas broncodilatadoras. O padrão de obstrução ao fluxo aéreo pulmonar pode ser mensurado pelo exame de espirometria, através da verificação da diminuição do volume expiratório no primeiro segundo (PROTOCOLO CLÍNICO E DIRETRIZES TERAPÊUTICAS - Portaria SAS/MS nº 709, de 17 de dezembro de 2010).

A etiologia da asma é multifatorial e envolve uma complexa interação entre prédisposição genética, eventos da primeira infância e exposições a antígenos ambientais (LEUNG; KO; WONG, 2013).

A inflamação das vias aéreas é o evento-chave da doença (BRANNAN; LOUGHEED, 2012). A inflamação provoca ao aumento da permeabilidade vascular, edema, aumento das secreções mucoides e hipersecreção de muco (GINA, 2013; NAUTA et al., 2008).

No Brasil, estima-se que a prevalência da asma seja em torno de $10 \%$ da população total do país (GINA-BRASIL, 2013) e que apenas no serviço público de saúde aconteçam cerca 350 mil internações hospitalares por ano em decorrência desta doença (TOYOSHIMA et al., 2005).

Uma vez que constitui a terceira maior causa de hospitalização do SUS (Sistema Único de Saúde) no Brasil, segundo dados do Ministério da Saúde, o gasto com a asma é estimado em R\$120 milhões por ano apenas na rede pública (DATASUS, 2013). Em 2005, por exemplo, ocorreram 2.050 óbitos registrados como provocados pela doença no Brasil (TOYOSHIMA et al, 2005) e em 2012 estima-se que este número tenha sido superior a 2.500 óbitos (DATASUS, 2013). No município de São Paulo, no período entre os anos de 1995 e 
2000, foram contabilizadas 206.764 internações por doenças respiratórias, dentre estas, 12,5\% foram decorrentes de asma (RIO; GALLO; SIQUEIRA, 2002). Em 2007, foram registrados 28.542 atendimentos por asma no estado de São Paulo (TELLES-FILHO, 2008). Estima-se em 6,5\% a mortalidade por asma no município de São Paulo (DATA SUS, 2013). Os dados referentes à outras regiões do Brasil são escassos, porém um estudo realizado nas cidades de Recife, Salvador, Itabira, Uberlândia, São Paulo, Curitiba e Porto Alegre concluiu que a média da prevalência da asma em crianças na faixa etária de 6 a 7 anos e 13 a 14 anos era de 13,3\% nestas cidades (ISAAC, 2012).

Em outros países a situação não é diferente. Segundo o informe do GINA - Global Initiative for Asthma, existem atualmente 300 milhões de pessoas com a doença no mundo (GINA, 2013). Nos Estados Unidos da América (EUA) a prevalência da asma aumentou significativamente entre 1980 a 1996, permaneceu estável de 1996 a 2001 e atualmente parece estar aumentando (AMERICAN LUNG ASSOCIATION, 2011). Em 2002, dados do NCHS (National Center for Health Statistics E-Stats) - Division of Data Services do Centers for Disease Control and Prevention (CDC) estimavam em 20 milhões (72 por 1.000) o número de pacientes com asma nos EUA. Isto representava 14 milhões de adultos (68 por 1.000) e 6,1 milhões de crianças (83 por 1.000) (GUIDELINES FOR THE DIAGNOSIS AND MANAGEMENT OF ASTHMA, 2008). Em 2007, 3.447 pessoas morreram de asma nos EUA, (aproximadamente 63\% deste total eram mulheres). Em 2009 um estudo epidemiológico demonstrou que cerca de 39.9 milhões de americanos (ou 132,5 a cada 1000) sofria de asma. Atualmente estima-se que uma pessoa a cada 12 seja asmática nos EUA (CENTER OF DISEASE CONTROL AND PREVENTION, 2013).

No Reino Unido, cinco milhões e meio de pessoas são afetadas atualmente pela asma, dentre as quais 1.1 milhões são crianças (uma a cada 11 crianças é asmática) (WATSON et al., 2007). Em 2010 ocorreram 1.143 registros de óbito por asma na Inglaterra (GINA, 2013).

$\mathrm{Na}$ Austrália, a asma acomete de 10 a 12\% dos adultos (ALMQVIST; WORM; LEYNAERT, 2008). Na França, a asma atinge de 6 a 7\% dos adultos (DELMAS; FUHRMAN, 2010). A prevalência da asma em países asiáticos varia de 5,2\% na Tailândia a $30 \%$ na Nova Zelândia. No Japão, 6,7\% da população é afetada pela doença (PAWANKAR et al., 2012).

Um levantamento realizado no Canadá demonstrou que os custos anuais com tratamento médico de pessoas asmáticas são comparáveis aos custos de pessoas com doenças infecciosas, doenças hematológicas, defeitos congênitos e lesões peri-natais. Também são comparáveis 
aos custos de pacientes que necessitam de home-care (ASTHMA SOCIETY OF CANADA, 2012).

Nos EUA, estima-se que o gasto anual com plano de saúde de indivíduos asmáticos seja aproximadamente 3 vezes maior do que o gasto com plano de não -asmáticos. O gasto anual provocado pelo absenteísmo de indivíduos asmáticos é cerca de $40 \%$ maior do que o gasto devido ao absenteísmo de indivíduos não-asmáticos (HASEGAWA et al., 2013).

Embora apresente distribuição universal, a doença possui um padrão de ocorrência de acordo com a faixa etária e gênero (ISAAC, 2012). A asma afeta igualmente crianças e adultos (TAKEDA et al., 2013). Na primeira infância, a asma é mais comum entre o sexo masculino, mas após a puberdade, a incidência aumenta no sexo feminino e diminui no masculino. $\mathrm{Na}$ idade adulta, a asma costuma ser mais grave em mulheres que em homens (SCALAN et al., 2009; SUNDBERG et al., 2013; TAKEDA et al., 2013).

A maior prevalência da asma em meninos na primeira infância pode ser demonstrada através das estatísticas de internações hospitalares, que são mais frequentes em meninos $(60 \%)$ do que em meninas (40\%). Este padrão se inverte na fase de adolescência (mulheres $68 \%$ e homens 32\%) (ALMQVIST et al., 2008). O número de hospitalizações por asma no sexo feminino é maior também na fase adulta (ANDERSON et al., 2013; ALMQVIST et al., 2008).

Além disso, os índices de remissão da doença são maiores para o sexo masculino. Um estudo acompanhou 3.430 crianças da idade de 7 até completarem 19 anos para avaliar a taxa de remissão da asma. Aos 19 anos de idade, 21\% dos pacientes acompanhados não apresentavam mais sinais da doença (remissão), 38\% apresentavam asma leve e esporádica e $41 \%$ apresentavam asma persistente. As taxas de remissão foram absolutamente maiores entre os meninos (91\%), e elevadas o suficiente para que o autor passasse a considerar o sexo masculino como fator preditivo para a ocorrência de remissão. (ANDERSON et al., 2013).

$\mathrm{O}$ fato de a asma afetar mais à mulheres do que a homens após a puberdade, remete a ideia de que os hormônios femininos exerçam alguma influencia sobre a evolução e a patogênese da doença.

Trata-se, portanto, de uma doença com grande importância epidemiológica no mundo todo e que demanda volumosos gastos com saúde pública. Dada à sua imensa prevalência, a asma é intensamente estudada, e mesmo assim, a doença não tem cura e ainda pouco se conhece sobre seus mecanismos de gênese e de controle endógeno. 


\subsection{Patogenia da asma}

O processo inflamatório crônico que caracteriza a asma inicia-se com a sensibilização alérgica das vias aéreas. A sensibilização é um fenômeno que ocorre a partir do contato do organismo com um agente sensibilizante (antígeno).

Importante ressaltar que o que caracteriza a alergia, é a propensão natural de alguns indivíduos de se tornarem sensibilizados e responderem com sinais e sintomas inflamatórios contra determinado agente ambiental normalmente não nocivo ou não tóxico. Esta "hipersensibilidade", também chamada de "atopia" (termo que vem do grego "atopos" significando "fora de lugar") se refere à produção de anticorpos contra algum agente ambiental após um primeiro contato com o mesmo.

Uma vez no organismo, este agente é reconhecido como estranho por algumas células de defesa (sistema imunológico). Estas células, as chamadas células apresentadoras de antígenos (APC), como por exemplo, os macrófagos e as células dendríticas, ligam-se a estes agentes, os processam e os apresentam à outras células de defesa: os linfócitos do tipo T (LT). O processamento de antígenos consiste no processo de endocitose pelas células apresentadoras de antígeno, na degradação proteolítica das proteínas antigênicas em peptídeos, na ligação dos peptídeos às moléculas recém-montadas do complexo de histocompatibilidade humano (MHC), e na exposição do complexo peptídeo-MHC à superfície das APCs de maneira a ocorrer o reconhecimento pelos LT (LAMBRECHT et al., 2000; SALLUSTO; LANZAVECCHIA, 2001; VERMAELEN et al., 2001).

Os LT por sua vez, estimulam outro tipo de linfócitos - os linfócitos B (LB) - a produzirem anticorpos específicos [imunoglobulina E (IgE)] para aquele agente sensibilizante.

A IgE produzida pelos LB liga-se a receptores $\mathrm{FcR}$ presentes na membrana dos mastócitos, basófilos e eosinófilos, completando-se a cascata de eventos chamada de sensibilização. Indivíduos sensibilizados para determinado agente, quando entram em contato novamente com o mesmo, desenvolvem o quadro sintomatológico típico de alergia (clássica resposta de hipersenssibilidade tipo I) (SCHOFIELD; CALHOUN, 2011; GALLI, 2008).

Apesar de se manifestar tipicamente com características de resposta de hipersensibilidade tipo I, nem toda a asma pode ser associada à atopia. Muitos indivíduos manifestam sintomas da asma deflagrados por estímulos não alérgicos. Cerca de $10 \%$ dos asmáticos reagem a estímulos físicos (temperatura fria, diminuição da umidade do ar), estímulos fisiológicos (exercício físico, stress psicológico, emoções intensas) e a substâncias 
irritantes (fumos, odores e etc) (ROCHAT, 2005). A asma não atópica é caracterizada por baixa geração de $\operatorname{IgE}$ e seus mecanismos fisiopatológicos não estão completamente esclarecidos (MANISE et al., 2013).

Uma vez ocorrida a ligação do antígeno com os receptores específicos presentes na parede de mastócitos e/ou basófilos previamente sensibilizados, tem-se o início da liberação maciça de um amplo espectro de substâncias químicas celulares, conhecidas como mediadores inflamatórios. A sinalização entre as diversas células do sistema imunológico ocorre por meio da liberação destas substâncias (para revisão ver SCHOFIELD; CALHOUN, 2011; YING, 2006; BRIGHTLING et al., 2002).

Atualmente, uma ampla gama de mediadores químicos inflamatórios já está reconhecida. Estas subtancias químicas variam de aminas vasoativas (histamina, serotonina, etc), mediadores lipídicos (eicosanoides), citocinas, quimiocinas, proteases, triptases até espécies reativas de oxigênio e nitrogênio (CHANG; TANG; LIN, 2013; SHMUEL; CORTEZ, 2013). Alguns destes mediadores já existem estocados nas células (pré-formados) e outros são sintetizados a partir de estímulos inflamatórios (mediadores neo-formados).

Os mediadores químicos regulam a resposta inflamatória de variadas maneiras, como por exemplo, estimulando ou facilitando a migração de células inflamatórias, promovendo a liberação de ouros mediadores químicos, alterando a permeabilidade vascular, Alterando a secreção de muco e o tônus da musculatura lisa (SCHOFIELD; CALHOUN, 2011).

A histamina é o mediador pré-formado mais classicamente associado à resposta alérgica imediata. Esta amina de baixo peso molecular é liberada por mastócitos, basófilos, neurônios histaminérgicos, linfócitos, células dendríticas e plaquetas. É um potente agente vasodilatador e sua liberação está associada a edema de mucosas e extravasamento vascular (LEE; YANG, 2013).

Além dos mediadores pré-formados, outros importantes mediadores inflamatórios são as citocinas. As citocinas são uma família de proteínas glicosiladas envolvidas na sinalização da resposta imune em diferentes níveis. São capazes de controlar a magnitude e o tipo de resposta inflamatória (GALLELLI; BUCETI; PALAIA, 2013). Crescimento celular, diferenciação, proliferação, quimiotaxia, imunomodulação e apoptose são algumas das ações destas substâncias (MANISE et al., 2013). As citocinas exercem seus efeitos através de sua interação com receptores específicos presentes nas superfícies das células-alvo. Estas substâncias exibem efeitos pleiotrópicos, tornando muito difícil determinar o papel específico e particular de cada uma na patogênese da inflamação de origem alérgica (HAMID; TULIC, 2009). 
Os eucosanóides são mediadores lipídicos originados da membrana celular a partir da molécula do ácido aracdônico. Os mediadores lipídicos possuem um grande envolvimento com a patogênese da asma. Prostaglandinas e leucotrienos estão relacionados à hiperreatividade das vias aéreas observada na asma (BRANNAN; LOUGHEED, 2012).

Outros mediadores inflamatórios incluem o fator de necrose tumoral $\alpha$ (TNF- $\alpha$ ), os fatores de crescimento: fator estimulante de colônia de macrófagos e granulócitos (GMCSF), fator de crescimento derivado de plaquetas (PDGF), o fator de crescimento tumoral (TGF), factor de crescimento de fibroblastos (FGF), e fator de crescimento epidérmico (EGF). (LEE; YANG et al., 2013).

A liberação destas substâncias em cascata durante a resposta alérgica aguda provoca efeitos nos tecidos-alvo, tais como aumento da permeabilidade vascular, edema de mucosas, hipersecreção de muco, broncoespasmo, e etc. (LEE; YANG et al., 2013), tal como podemos observar na figura 1.

Figura 1 - Representação dos efeitos inflamatórios da asma nas vias aéreas

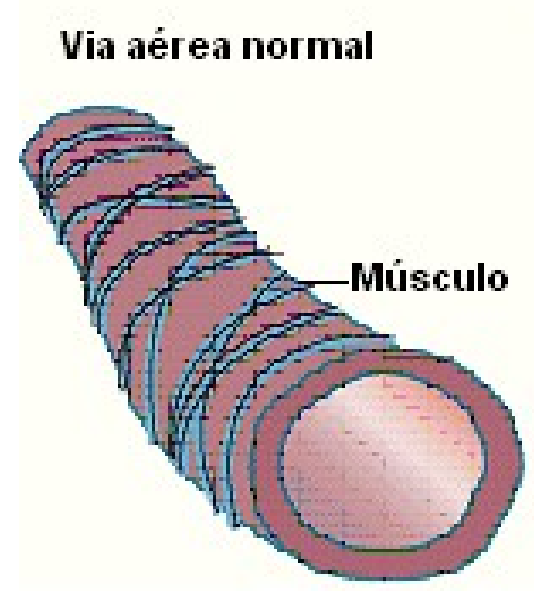

\section{Asma}

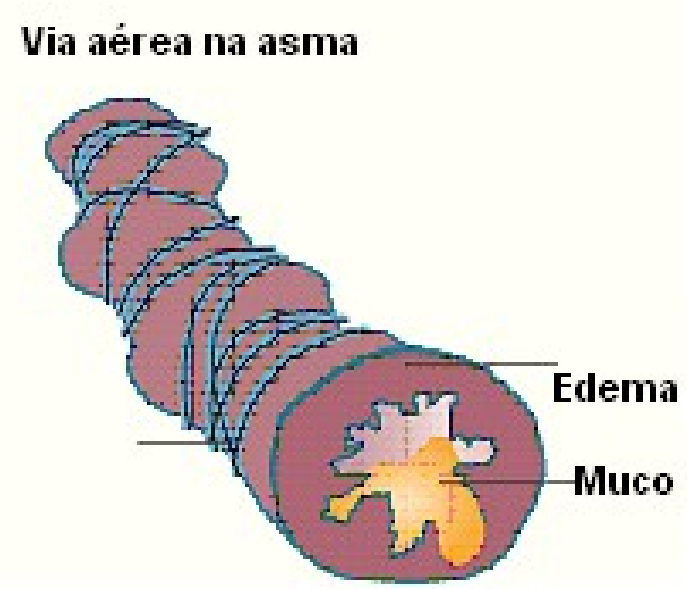

À esquerda observa-se a representação de um bronquíolo normal e à direita o bronquíolo durante a crise asmática, com aumento das secreções mucóides em seu interior e estreitamento da sua luz por edema e contração das fibras musculares lisas, dificultando assim o fluxo aéreo e provocando os sintomas da asma.

Fonte: Google images

Além de provocar estes efeitos diretos, a liberação local de mediadores durante a resposta alérgica aguda também funciona como estímulo para a migração de outras células do sistema imunológico provenientes da circulação sistêmica. Esta propriedade atrativa é conhecida como quimiotaxia. Mediadores como o TNF- $\alpha$, leucotrieno B4 (LTB4) e a interleucina 8 (IL-8) promovem recrutamento de leucócitos, levando à infiltração de células inflamatórias sistêmicas para o pulmão. Linfócitos, neutrófilos, eosinófilos, monócitos, 
basófilos, e células "Natural Killer" (NK) migram para o microambiente pulmonar, integrando-se ao processo e dando continuidade à resposta alérgica. Plaquetas, fibroblastos e células musculares lisas também participam da inflamação crônica (YANG et al., 2005).

Classicamente, linfócitos e eosinófilos são considerados as principais fontes de citocinas na asma. Atualmente, entretanto, sabe-se que diversas citocinas são produzidas por células estruturais, tais como: células epiteliais, células endoteliais e fibroblastos.

A resposta imunológica celular na asma é dominada pelo subtipo linfocitário Th2. Os linfócitos $\mathrm{T}(\mathrm{CD} 4+)$ são funcional e fenotipicamente classificados como Th1 e Th2. As abreviaturas Th1 e Th2 referem-se a linfócitos T "helper" 1 e 2 ou LT-auxiliares (HIRAHARA et al., 2013). Os linfócitos T primordiais ou naive diferenciam-se em Th1 ou Th2 conforme a sinalização efetuada pelas células apresentadoras de antígeno e mediadores. A diferenciação para a linhagem Th1 é induzida principalmente por IL-12. A diferenciação para células Th2 é induzida por IL-4 (HAMID; TULIC, 2009; SCHOFIELD; CALHOUN, 2011).

Muitos autores propõem que o desequilíbrio entre as populações de linfócitos Th1/Th2 exerça papel central na patogênese da asma (SHMUEL; CORTEZ, 2013; GALLI, 2008; YASDANBAKHSH et al., 2002), entretanto, este desequilíbrio ainda não foi capaz de explicar completamente a patogênese da asma (SHI et al., 2013). Evidencias advindas de análises de secreção mucoide ou de LBA de pacientes com asma grave, demonstram padrões celulares e de liberação de citocinas diferentes do Th2 (MANISE et al., 2013). Além disso, pacientes com asma persistente podem apresentar frequentemente inflamação neutrofílica (KIM et al., 2013).

De fato, a inflamação com padrão Th2 continua a ser a mais frequentemente encontrada em pacientes com asma leve e moderada (LEE; YANG, 2013). Além disso, embora seu papel não esteja completamente esclarecido, os linfócitos Th17 também estão associados à patogênese da asma. Existe o aumento da expressão de seu RNAm em modelo murino de inflamação pulmonar crônica (HELLINGS et al., 2003a, b) e nas secreções respiratórias de pacientes asmáticos (AL-RAMLI et al., 2009).

Os LTreg estão associados à supressão e ao controle da resposta inflamatória alérgica. Recentemente foi proposto por Shi e colaboradores que a resposta inflamatória alérgica na asma grave pode ser provocada por uma diminuição das populações de linfócitos Treg (SHI et al., 2013). Os linfócitos Treg (CD4+CD25+Foxp3+) exercem sua função supressora através do contato célula a célula ou por intermédio da liberação de IL-10 e TGF- $\beta$. Os Treg são capazes de inibir a maturação de LTh2, possivelmente através da inibição da produção de IL- 
4. Por outro lado, os LTh2 são capazes de induzir apoptose em células Treg controlando sua população (SHI et al., 2013). Existe, portanto, uma regulação mútua entre estas células durante o processo inflamatório alérgico.

As células inflamatórias estimuladas liberam substâncias neo-formadas e fatores de crescimento. As substâncias neo-formadas são liberadas mais lentamente que os mediadores pré-formados. Algumas populações de mastócitos são capazes de liberar grande volume de substâncias neo-formadas incluindo TNF- $\alpha$. Acredita-se que as reações de fase tardia sejam coordenadas em parte por efeitos deflagrados pelos mediadores químicos liberados pelos mastócitos e em parte diretamente pelos linfócitos Th2 estimulados. (GALLI; TSAI; PILIPONSKY, 2008; LEE; YANG et al., 2013).

A quimiotaxia provoca migração de células inflamatórias sistêmicas para as vias aéreas e a liberação lenta de mediadores químicos neo-formados promove a perpetuação do processo inflamatório. Estes eventos são responsáveis pela permanência da resposta alérgica mesmo após a exposição ao antígeno já ter cessado. Desta maneira, o processo agudo pode facilmente se prolongar. $\mathrm{Na}$ asma, eventos inflamatórios prolongados modificam toda a fisiologia pulmonar.

\subsection{Cronificação do processo inflamatório remodelamento pulmonar na asma}

Por conta da reação alérgica contínua (ou recorrente) da asma, a inflamação tecidual crônica leva ao desenvolvimento de modificações permanentes na estrutura da árvore brônquica. O conjunto das modificações que ocorrem ao longo do tempo foi denominado de remodelamento das vias aéreas (BOUSQUET et al., 2004). 
Figura 2- Representação da inflamação crônica das vias aéreas na asma

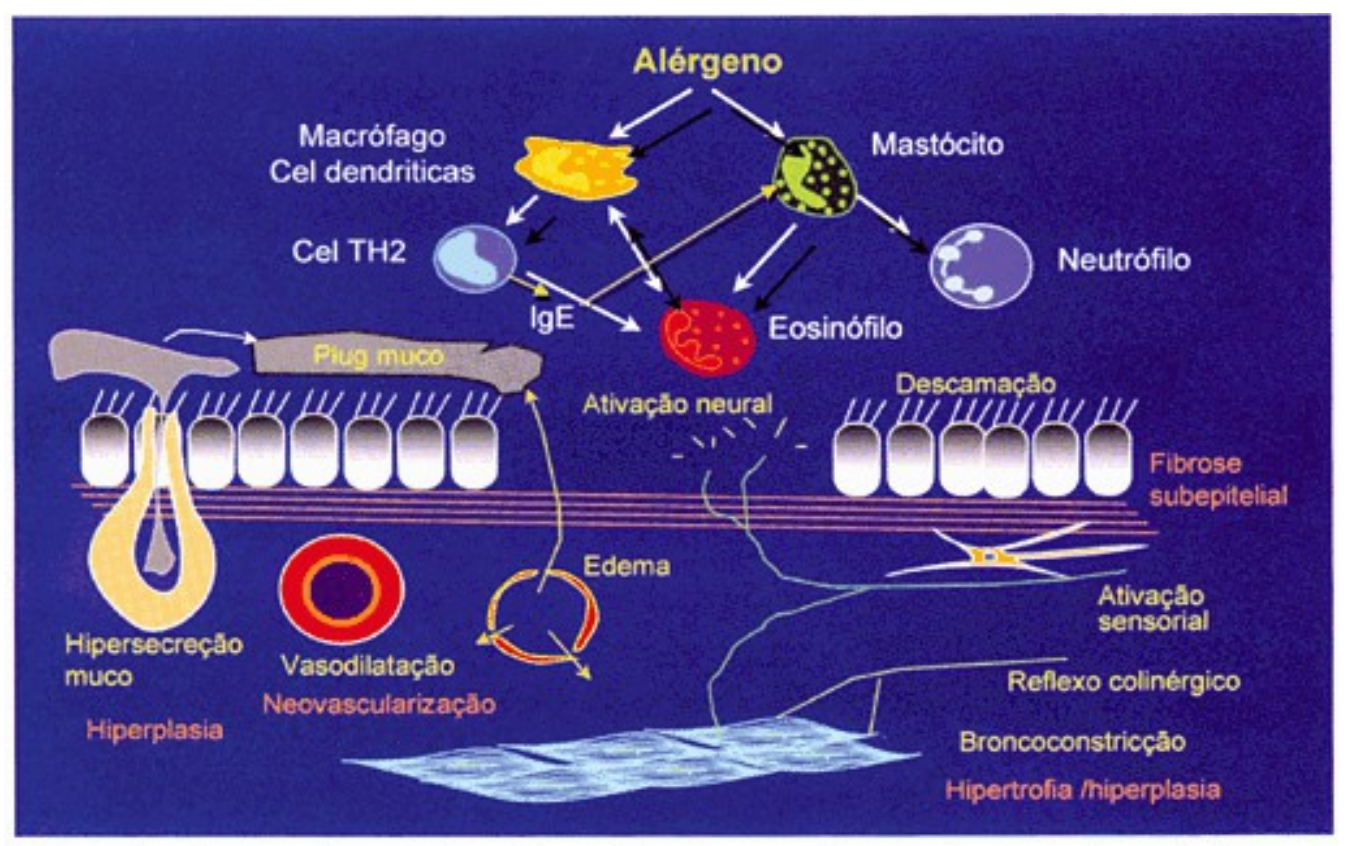

Após o remodelamento, pode-se observar nos bronquíolos: hipertrofia/hiperplasia do músculo liso, hiperplasia das glândulas mucosas e deposição de colágeno na membrana basal. Fonte: Jornal de Pneumologia. vol. 28, Supl.1, 2002.

O remodelamento é caracterizado pela deposição de colágeno sob a membrana basal do epitélio brônquiolar, por hiperplasia e hipertrofia de musculatura lisa das vias aéreas, por hiperplasia e metaplasia das células caliciformes epiteliais, neoformação vascular, neoformação nervosa e deposição de proteínas na matriz extracelular (BOUSQUET et al., 2004; ELIAS et al., 2000; YING et al., 2006).

Os mecanismos indutores do remodelamento das vias aéreas na asma ainda não estão totalmente compreendidos, todavia, sabe-se que os mediadores inflamatórios presentes no processo alérgico estão diretamente relacionados aos eventos que levam ao remodelamento. A presença de múltiplas citocinas, quimiocinas e fatores de crescimento liberados por células inflamatórias e estruturais nas vias aéreas proporciona um complexo conjunto de estímulos, que em última instancia, conduzem às modificações teciduais que caracterizam o remodelamento (ELIAS et al., 2000; LEDERLEEN e al., 2009).

Muitos tipos celulares participam da inflamação crônica alérgica, incluindo linfócitos $\mathrm{CD} 8+$, células T regulatórias (TReg), linfócitos tipo natural killer (NK) e células estruturais como: células epiteliais, células musculares lisas e fibroblastos. 
Acredita-se que os mastócitos estão mais presentes durante a resposta inflamatória aguda (AL-MUHSEN; HAMID; JOHNSON, 2011) enquanto na fase tardia, a inflamação é orquestrada por eosinófilos e LTh2 (SHINAGAWA; KOJIMA, 2003).

Recentemente um novo tipo de linfócito não-B/não-T, denominado linfócitos tipo 2 (ILC2s), que produz IL-5 e IL-13, foi relacionado à patogênese da asma (HENDRICKS; WOLTERINK, 2013).

Os eosinófilos desempenham papel crítico no processo de remodelamento (FULKERSON; ROTHERBERG, 2011; SHINAGAWA; KOJIMA, 2003) pois constituem uma das principais fontes de TGF- $\beta$, citocina pró-fibrótica (HALWANI et al., 2011), além de serem fonte de eicosanoides, cistenil leucotrienos, espécies reativas de oxigênio, e de outros mediadores. Acredita-se que os eosinófilos presentes na fase tardia do processo inflamatório, em conjunto com os LTh2, sejam um dos principais responsáveis pela manutenção da resposta inflamatória e consequentemente pelo remodelamento tecidual (SHINAGAWA; KOJIMA, 2003).

Um dos eventos mais relevantes no remodelamento é o aumento da massa muscular lisa das vias aéreas.

O aumento da massa muscular lisa nas vias aéreas durante o processo de remodelamento pulmonar está associado à diferenciação de fibroblastos em miofibroblastos, à migração de fibroblastos para as vias aéreas e à presença aumentada de fatores de crescimento no local produzindo hipertrofia das células musculares lisas das vias aéreas (JAMES et al., 2012)

A migração e diferenciação dos fibroblastos leva ao aumento de fibrócitos nas vias aéreas. Fibrocitos são células CD34+ que produzem colágeno tipo I. Estudos com indivíduos asmáticos demonstraram que a exposição ao alérgeno resulta em acumulação de fibrócitos nas membranas subepiteliais das vias aéreas em áreas ricas em colágeno. O número de fibrócitos está aumentado no lavado bronco-alveolar (LBA) de pacientes asmáticos não tratados e a quantificação dos fibrócitos recrutados nas vias aéreas de asmáticos se relaciona ao grau de estreitamento de sua membrana basal (CAMORETTI-MERCADO et al., 2009).

Estudos anátomo-patológicos demonstram que o número de fibrócitos das vias aéreas de indivíduos asmáticos com obstrução de fluxo aéreo pulmonar é maior do que daqueles sem obstrução de fluxo aéreo, reforçando a ideia de que estas células se relacionam com a hipetrofia do músculo liso das vias aéreas observada no remodelamento pulmonar (CAMORETTI-MERCADO et al., 2009). 
Os miofibroblastos são as células efetoras primárias nos processos de fibrose pulmonar (SCOTON; CHAMBERS, 2007). São caracterizados fenotípicamente pela expressão de proteínas contráteis como as fibras de actina tipo alfa e pela sua elevada síntese de colágeno. Eles são derivados da ativação/proliferação de fibroblastos residentes no tecido pulmonar ou da diferenciação de células mesenquimais do epitélio das vias aéreas, ou ainda do recrutamento de células-tronco fibroblásticas circulantes (fibrócitos) (SCOTON; CHAMBERS, 2007).

Os miofibroblastos quando ativados desempenham um papel importante no remodelamento do microambiente pulmonar tanto por conta de sua proliferação excessiva como através da liberação de mediadores inflamatórios. (WARD et al., 2008).

As citocinas predominantemente associadas à proliferação local de miofibroblastos durante o processo de remodelamento das vias aéreas incluem: TGF- $\beta$, fator de crescimento derivado de plaquetas (PDGF), IL-6, IL-11, IL-13, IL-17 e IL-25 (JAMES et al., 2012).

$\mathrm{Na}$ asma, o aumento local de tecido muscular liso leva a uma diminuição de calibre das vias aéreas devido ao aumento da espessura de sua parede e a uma maior força de contração durante as crises de hiperreatividade deflagrada pelo contato com os antígenos. Embora não seja consenso, existe indicação de que o próprio fenômeno de hiperreatividade das vias aéreas na asma também esteja associado à estas modificações (NAUTA et al., 2008).

O TGF- $\beta$ é uma citocina associada à proliferação (hipertrofia) do tecido muscular liso. Constitui um dos principais fatores indutores de mitose com sua bem conhecida capacidade de estimular proliferação de fibroblastos, células epiteliais, e células musculares lisas vasculares. Esta citocina tem sido relacionada à alterações estruturais das vias aéreas em diversas doenças pulmonares crónicas (SCOTON; CHAMBERS, 2007).

O TGF- $\beta$ também é uma potente citocina pró-fibrotica. As principais fontes de TGF- $\beta$ incluem fibroblastos, eosinófilos e células epiteliais, no entanto, macrófagos, monócitos, neutrófilos e linfócitos também podem produzi-lo. O TGF- $\beta$ induz a produção e a liberação de citocinas pró-fibróticas e pró-inflamatórias pelos fibroblastos, enquanto inibe a proliferação e a liberação de citocinas nos monócitos, linfócitos e epiteliais células (HAMID; TULIC, 2009). O TGF- $\beta$ pode estar envolvido no processo de reparação de células epiteliais das vias aéreas em condições fisiológicas. A produção local de TGF- $\beta$ por eosinófilos durante o processo inflamatório asmático pode ser responsável pela fibrose subepitelial observada após o remodelamento das vias aéreas (HAMID; TULIC, 2009).

Outra citocina associada a hipertrofia muscular lisa é o PDGF. Ward e colaboradores demonstraram que fibroblastos de doentes asmáticos são mais reativos à PDGF (WARD et al., 
2008). Esta citocina também promove produção de colágeno. Eosinófilos são suas principais fontes celulares, no entanto, as plaquetas, macrófagos, células epiteliais das vias aéreas e endoteliais, células musculares lisas vasculares e fibroblastos, também produzem e liberam PDGF. Sua produção pode ser induzida por stress oxidativo ou mecânico, como também através do estímulo de outras citocinas, incluindo IFN- $\gamma$, TNF- $\alpha$, IL-1 e TGF- $\beta$. Embora o PDGF desempenhe um papel importante no remodelamento, acredita-se que sua atuação ocorra sempre em conjunto com outras citocinas (em particular com o TGF- $\beta$ ) alterando a composição estrutural da parede das vias aéreas (JAMES et al., 2012).

Outro importante potente agente mitogênico para músculo liso é a IL-6. Camundongos geneticamente manipulados para apresentarem superexpressão de IL-6 em suas vias aéreas desenvolvem fibrose subepitelial, deposição de colágeno e acumulação crescente de $\alpha$-actina em suas células de músculo liso, embora não apresentem eosinofilia, hiperreatividade ou metaplasia de células produtoras de muco (ELIAS, 2000). Esta interleucina pode estimular a produção de citocinas por linfócitos $\mathrm{T}$ e linfócitos $\mathrm{B}$ contribuindo assim para a perpetuação do processo inflamatório local (SHIFFREN et al., 2012).

As IL-11 e IL-13 foram recentemente alvo de grande atenção enquanto principais citocinas associadas ao remodelamento, uma vez que além de induzir fibrose e deposição de colágeno, também induzem hiperplasia de miofibroblastos, diminuição de calibre de vias aéreas, e hiperreatividade brônquica. Suas principais fontes incluem células epiteliais, fibroblastos, eosinófilos e células musculares lisas. (SHIFFREN et al., 2012).

Muito do que se conhece sobre o papel destas citocinas no processo de remodelamento das vias respiratórias vem de estudos que utilizam camundongos transgênicos.

Análise histológica de vias aéreas de camundongos com superexpressão de IL-11 ou IL13 por exemplo, demonstrou espessamento das paredes das vias respiratórias, alargamento alveolar, fibrose subepitelial do tecido e da adventícia, deposição de colágeno tipo I e tipo III e aumento do número de células contráteis e inflamatórias quando comparados com controles (SHIFFREN et al., 2012). Além disso, camundongos transgênicos com superexpressão de IL11 e IL-13 apresentam maior estreitamento de vias aéreas e de membrana basal e respondem com mais intensidade à metacolina inalada. Evidências recentes sugerem que um dos mecanismos pelos quais a IL-13 induz à fibrose tecidual seja através da estimulação seletiva e ativação da produção de TGF- $\beta$. (HAMID; TULIC, 2009).

Desta forma, diversos processos podem contribuir para o remodelamento do músculo liso das vias aéreas, incluindo a proliferação e migração de miócitos, ativação e diferenciação 
de fibroblastos para miofibroblastos, recrutamento de fibrócitos e de células progenitoras mesenquimais circulantes (CAMORETTI-MERCADO et al., 2009).

Estudos de ultra-estrutura das vias aéreas remodeladas, confirmam o aumento do teor de fibras colágenas na membrana basal do epitélio e alterações na composição da matriz extracelular do pulmão (CORRY et al., 2004; MARGULIS et al., 2009; PARKS; SHAPIRO, 2001; RACKÉ et al., 2007).

Além das citocinas pró-fibróticas que promovem acúmulo de colágeno, neste processo também estão envolvidas as metaloproteinases, que clivam proteínas estruturais da matriz extracelular como as fibras colágenas e de elastina (AMMIT et al., 2005).

As metaloproteinases de matriz (MMPs) são proteínas da família das endopeptidases dependentes de zinco que medeiam a desintegração e reconstituição da matriz extracelular. As MMPs são produzidas por uma variedade de células, incluindo macrófagos, neutrófilos, células epiteliais e fibroblastos (PARKS; SHAPIRO, 2001). Vale lembrar que num pulmão sadio, as MMPs e seus inibidores fisiológicos (inibidores teciduais de MMPs de matriz, sigla em ingles: TIMPs) são produzidas por diversas células que compõem a estrutura das vias aéreas. Assim, a perda da regulação entre o equilíbrio de células do sistema imunológico pulmonar e de suas citocinas, parece exercer papel importante na sinalização para a transcrição de MMPs de matriz (GUEDERS et al., 2005).

Dentre 28 tipos diferentes de MMPs reconhecidas até o momento, a MMP-2 e a MMP9, também conhecidas como gelatinases A e B, degradam colágeno tipo IV, maior componente da membrana basal epitelial das vias aéreas. Estas proteases endógenas são intensamente expressas em sítios inflamatórios E não apenas degradam macromoléculas de matriz, mas também contribuem para ativação e liberação de diversas citocinas como: TNF- $\alpha$, IL-1 $\beta$ ou TGF- $\beta$, modulando portanto, ativamente o processo inflamatório (LÈNIEWSKA et al., 2009; MAcKLEROY et al., 2013). Podem ser produzidas por células inflamatórias e não inflamatórias no pulmão, além de digerir diversos componentes da matriz extracelular. Níveis elevados de MMP-9 foram observados na fibrose pulmonar idiopática, no enfisema pulmonar e na fibrose cística (OKAMOTO et al., 2004). Além da degradação de colágeno possuem outras funções tais como a quebra de proteínas transmembrana e de fatores teciduais embebidos na matriz extracelular como por exemplo: fatores de crescimento latentes e suas proteínas ligantes, moléculas quimiotáticas e citocinas (CHEN et al., 2013).

A MMP2 e a MMP9 possuem diversas características em comum. Ambas são reguladas pelas citocinas IL-4 e IL-13, ambas têm perfis semelhantes de substrato, de organizações de 
domínios e de estrutura, contudo, as duas diferem em sua expressão tecidual (LÈNIEWSKA et al., 2009). Camundongos deficientes em MMP2 exibem diminuição de migração de células inflamatórias e são propensos à asfixia (CORRY et al., 2002). A migração diminuída de células na ausência de MMP2, ocorre porque embora o recrutamento permaneça eficiente, o gradiente de quimiotaxia torna-se diminuído. A ingresso de eosinófilos no lúmen alveolar diminui em camundongos deficientes de MMP2. Células imunes recrutadas em sítios inflamatórios expressam MMP9, mas o papel fisiológico desta enzima nos sítios inflamatórios permanecem desconhecidas (MAcKLEROY et al., 2013) Acredita-se que as MMPs, além de participar da regulação e do controle do tráfego de células inflamatórias também exerçam papel importante na degradação (clearence) das células inflamatórias pré-apoptóticas dentro do pulmão alérgico. Camundongos nockout para MMP2 exibem um número diminuído de células inflamatórias no lavado bronco-alveolar (LBA). Camundongos deficientes para MMP9 por sua vez, demonstram diminuição específica de neurófilos e de eosinófilos no LBA (CORRY et al., 2004).

Durante o processo de remodelamento das vias aéreas, as modificações sofridas pelas células musculares lisas, o aprisionamento de células inflamatórias e o aumento do colágeno na matriz extracelular alteram a arquitetura bronquiolar e conseqüentemente sua capacidade de contração e relaxamento resultando em doença asmática persistente (HIRST et al., 2000).

Diversos estudos in vitro revelam a existência de proliferação das células musculares lisas, quando estimuladas por diferentes mediadores pró-inflamatórios, fatores de crescimento e componentes da matriz extracelular (GASEINS et al., 2008). No entanto, os mecanismos envolvidos no aumento da liberação de mediadores que promovem a proliferação da musculatura lisa das vias aéreas in vivo ainda não foram esclarecidos.

Além da redução geométrica ao fluxo aéreo provocada pelo edema e pelo espessamento epitelial das vias aéreas, a proliferação das células musculares lisas causa uma mudança no perfil normal de liberação de citocinas e de matriz extracelular. Uma visão mais contemporânea do papel da musculatura lisa no remodelamento das vias aéreas, permite, portanto, que as células musculares lisas sejam consideradas como verdadeiros imunoefetores não apenas pela sua proliferação, mas também pelo aumento de secreção de citocinas, expressão de moléculas de adesão e interação com várias células inflamatórias (CHEN et al., 2013).

As alterações fenotípicas observadas na asma têm como principal conseqüência a perpetuação dos sintomas e o orquestramento do processo inflamatório nas vias aéreas 
contribuindo dessa forma para o agravamento progressivo da doença e para uma menor resposta à terapêutica (McKAY et al., 2000).

O remodelamento das vias aéreas, tal como o que ocorre na asma, torna ruim o prognóstico da doença em indivíduos com crises freqüentes, visto que o enrijecimento contínuo das paredes brônquiolares modifica permanentemente seu calibre, altera a expansibilidade pulmonar e conseqüentemente reduz o fluxo aéreo respiratório. Estes fatores associados à presença de tampões de muco provocados pelas secreções exacerbadas, provocam mini-atelectasias e modificam consideravelmente, a mecânica ventilatória do asmático.

\subsection{Hormônios sexuais femininos e asma}

Evidências clínicas e experimentais mostram que existe uma grande influência das oscilações hormonais observadas durante o ciclo sexual feminino na exacerbação dos sintomas da asma. Em 1931 o médico Robert T. Frank foi pioneiro em descrever o caso de uma mulher que sofria suas mais sérias e debilitantes crises de asma durante o período prémenstrual. Estabeleceu-se pela primeira vez, uma relação entre a piora e a gravidade das crises asmáticas com as oscilações na concentração dos hormônios sexuais femininos (FRANK et al., 1931). Posteriormente, estudos conduzidos por Skobeloff, (1996) indicaram que 30 a 40\% das mulheres asmáticas apresentam deterioração de sintomas como tosse, sibilância e dispnéia nos dias que precedem à menstruação. Esta exacerbação se observa no período do segundo ao quinto dia que antecede o sangramento menstrual (CHHABRA et al., 2005; SKOBELLOF et al., 1996). Vale lembrar que justamente nesta fase do ciclo sexual feminino ocorrem alterações significativas dos níveis circulantes dos hormônios sexuais (figura 3). Admite-se que as oscilações dos hormônios sexuais femininos sejam responsáveis pela maior tendência à piora da asma brônquica (BALZANO et al., 2001; CHHABRA et al., 2005; VRIEZE et al., 2003). É interessante notar que no homem, não existem variações significativas nos níveis circulantes do hormônio sexual e nem alterações diárias ou semanais. A testosterona alcança seu pico máximo na adolescência ocorrendo lenta e gradual diminuição dos seus níveis plasmáticos até a velhice (ANTUNES et al., 2010; AUGER; JOUANNET, 2005).

Levantamentos epidemiológicos reforçam a relação entre asma e hormônios sexuais femininos. A prevalência de asma nos EUA em indivíduos após os 18 anos de idade é mais elevada entre mulheres, com uma taxa de aproximadamente $63,9 \%$ contra $44,4 \%$ de homens 
(ABRAMSON et al., 1996; STRACHAM et al., 1996). No ano de 2009, um total de 10,3 milhões de homens e 14.2 milhões de mulheres tinham asma, com uma taxa de prevalência de 69,9 homens a cada 1000 pessoas asmáticas e de 92,7 mulheres a cada 1000 pessoas asmáticas (33\% a mais que o número de homens asmáticos). Entre adultos acima de 18 anos, mulheres tinham $76 \%$ mais chance de apresentar asma e entre crianças este padrão se invertia. A prevalência em meninos abaixo de 18 anos era $44 \%$ maior do que a prevalência em meninas (CDC, 2009). A mortalidade e a hospitalização por asma são também mais elevadas no sexo feminino (CHEN et al., 2003; RHODES et al., 2005).

$\mathrm{Na}$ Suécia estudos demonstram que a maior incidência de asma se encontra no grupo populacional de mulheres entre 16 e 20 anos de idade (TORRÈN et al., 1999). Dados da literatura sobre a influência do gênero e da idade sobre as hospitalizações por asma revelaram que entre 20 e 50 anos de idade, a taxa de incidência de admissão em emergência hospitalar por asma é de 3 mulheres para cada homem (SKOBELLOF et al., 1992). Em 2002, no Brasil, as mortes por asma no sexo feminino foram $40 \%$ mais elevadas do que no sexo masculino (TELLES FILHO, 2007). De acordo com o DATASUS, desde o ano de 1995 até o ano 2000, o número de internações por asma no Brasil revela-se constantemente maior no sexo feminino (TOYOSHIMA et al., 2005).

Levantamentos epidemiológicos demonstram que em crianças, antes da puberdade, a doença é mais comum em meninos, e na pós-puberdade torna-se mais freqüente em meninas (ABRAMSON et al., 1996; STRACHAM et al., 1996). Seja onde for, as consideráveis diferenças entre homens e mulheres em relação à asma, freqüentemente observadas na clinica ou em estudos epidemiologicos reforçam a percepção de que existe um importante papel exercido pelos hormônios sexuais femininos na indução da doença.

Vários autores associam a piora da asma no período pré-menstrual à queda brusca dos níveis de estrógenos observada no período pós-ovulatório e no período que antecede a menstruação (CHHABRA et al., 2005; ENSON et al., 2003; TAN et al., 2001; VRIEZE et al., 2003).

Existem, no entanto, dados que sugerem a existência de correlação entre a asma prémenstrual (APM) e o aumento da relação estrogênio-progesterona (E:P) circulante. Admitese, nesta hipótese, que a progesterona exerça ação protetora, provavelmente anti-inflamatória, razão pela qual sua redução altere a relação E:P e facilite o desenvolvimento da asma (BEYNON et al., 1988).

A avaliação dos dados experimentais acerca da influencia dos HSFs na asma disponíveis na literatura muitas vezes apontam para direções divergentes dificultando 
conclusões. De fato, alguns estudos, especialmente aqueles que investigam a migração de células inflamatórias, geração de citocinas e dosagens de imunoglobulinas, são capazes de demonstrar que camundongos fêmeas quando comparados aos machos apresentam maior inflamação pulmonar após padrões de desafios alérgicos (DIMITROPOULOU et al., 2008). Outros porém utilizando parâmetros mecânicos das vias aéreas como resistência e elastância, revelam que machos são mais sensíveis que fêmeas à desafios alérgicos com metacolina e que camundongos geneticamente desprovidos de receptores de estrógenos possuem reatividade brônquica aumentada a desafios alérgicos. (CARD et al., 2006; CAREY et al., 2007). Esta aparente dicotomia de efeitos observados dificulta a interpretação das ações hormonais no controle da resposta inflamatória na asma.

Estudos realizados pelo nosso grupo revelaram que os hormônios sexuais femininos medeiam o recrutamento celular e a geração de citocinas em modelo agudo de inflamação pulmonar alérgica (DE OLIVEIRA et al., 2004). Todavia os mecanismos subjacentes à piora da asma em relação à variação dos HSF ainda não foram esclarecidos.

Figura 3 - Oscilações hormonais do ciclo sexual feminino humano

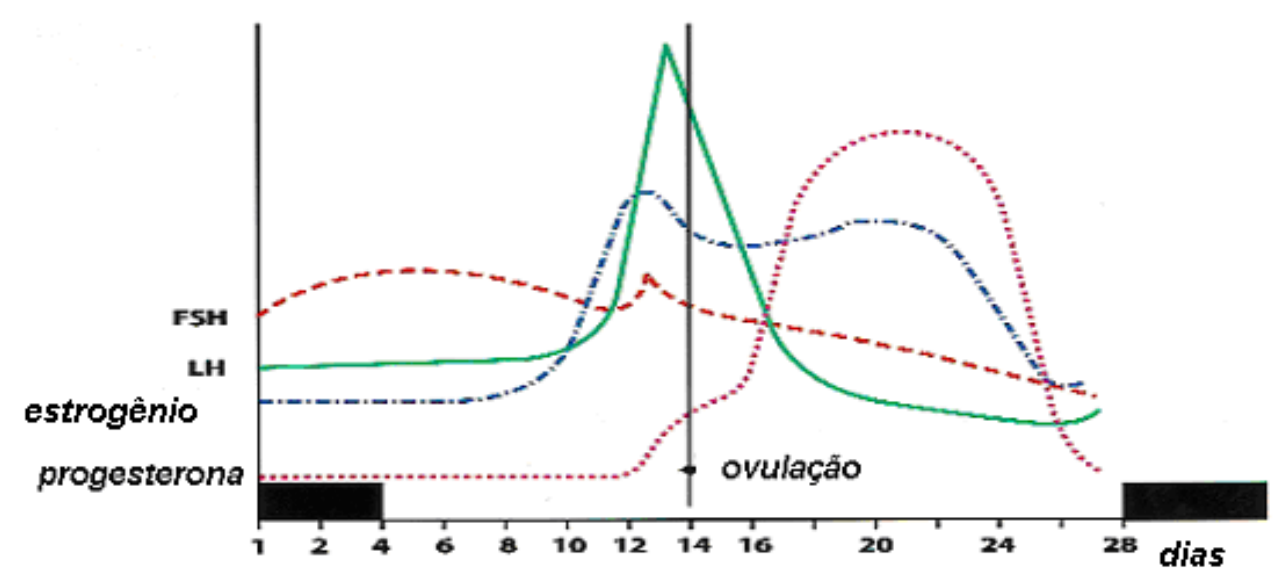

Variações específicas nas taxas de secreção de cada hormônio participante do ciclo sexual feminino ao longo dos dias do ciclo. A menstruação ocorre após o vigésimo oitavo dia, representada pela faixa negra no gráfico. A exacerbação da asma geralmente se observa do vigésimo terceiro ao vigésimo sexto dia do ciclo.

\subsection{Hormônios sexuais femininos e inflamação}


Estudos experimentais de inflamação indicam que os esteróides sexuais afetam a estrutura e a função do timo, modulam a atividade funcional de linfócitos T, B e de células NK (ASAI et al., 2001; IZUMI et al., 1995). Os esteróides sexuais também interferem com a produção de citocinas inflamatórias em camundongos: inibem a produção de IL-1 $\beta$ e TNF- $\alpha$ por monócitos/macrófagos e ainda interagem com o sistema neuro-endócrino através do eixo hipotálamo-hipofise-adrenal modificando a taxa de secreção de hormônio do crescimento e de prolactina (BURGER; DAYER, 2002).

Evidências apoiam o papel pró-inflamatório dos esteróides sexuais femininos, em especial os estrógenos (COLLINS et al., 1993; PFEILSCHIFTER et al., 2002; SPEYER et al., 2005). Estudos indicam ainda que mulheres na pós-menopausa têm reduzido número células inflamatórias secretando TNF- $\alpha$ e INF- $\gamma$ (COHEN et al., 2005; TROISI et al., 1995; VERTHELYI; KLINMAN, 2000). Os HSFs aumentam a expressão de E-selectina em células endoteliais de camundongos após estimulo com TNF- $\alpha$ (AZIZ; WAKEFIELD, 1996). Os estrógenos também aumentam a secreção de TNF- $\alpha$ em células mononucleares circulantes (ASAI et al., 2001). Outros estudos, porém, sugerem efeitos anti-inflamatórios dos estrógenos, visto que está demonstrado o aumento dos níveis de IL-6 e TNF- $\alpha$ no sangue de camundongos fêmeas ovariectomizadas (DESWAL et al., 2001, GIRASOLE et al., 1999). Foi demonstrado que neutrófilos diminuem sua migração tecidual quando expostos à presença de 17- $\beta$-estradiol in vivo (DILLARD; BODEL, 1972; SPANGLER et al., 1969; WOLFF et al., 1967). Estudos in vitro indicam que macrófagos murinos submetidos à exposição de 17- $\beta$ estradiol sintetizam quantidades reduzidas de IL-1, IL-6, e TNF- $\alpha$ (DESHPANDE et al., 1997).

Diversos autores evidenciaram o aumento da produção de IL-1 $\beta$, IL-6 e TNF- $\alpha$ por monócitos, macrófagos e osteoblastos durante a deficiência de estradiol (JILKA et al., 1992; PACIFICI et al., 1991; KIMBLE et al., 1994; KITASAWA et al., 1994).

Os estudos conduzidos por Puder et al. (2001), indicaram que a liberação de IL-1 $\beta$, IL6, TNF- $\alpha$ bem como a resposta do eixo hipotálamo-hipófise-adrenal a baixas doses de endotoxina, são atenuadas em mulheres na pós-menopausa e que estejam sob reposição hormonal com estradiol. Estes dados reforçam que concentrações fisiológicas de estradiol bem como aquelas administradas em protocolos de reposição hormonal podem reduzir a resposta neuroendócrina a desafios inflamatórios (PUDER et al., 2001). Dados obtidos por Salem et al. (2000), sugerem que a inibição inflamatória mediada pelo estradiol pode ser 
devida à combinação de efeitos de supressão e de ativação de células inflamatórias e de seus produtos (SALEM et al., 2000).

Uma gama de outras ações teciduais dos estrógenos poderiam influenciar a resposta inflamatória crônica. Por exemplo, os efeitos dos estrógenos são frequentemente relacionados a alterações celulares que podem culminar com a carcinogênese (FRASOR et al., 2003, PIETRAS et al., 2003, SOARES et al., 2004, UEHARA et al., 2004). As alterações celulares que levam às mutações carcinogênicas são mediadas pelos receptores teciduais de estrogênios, os quais fazem parte da superfamília de receptores de fatores nucleares de transcrição ativados por ligantes (receptores de estrógenos tipo $\alpha$ tipo $\beta$ ). Estes receptores mantém a homeostase celular por meio de complexos mecanismos de regulação da transcrição genética (FRASOR et al., 2003).

Além disso, os estrógenos exercem efeitos no sistema cardiovascular e sobre a musculatura lisa vascular (QIAO et al., 2008). O $17 \beta$-estradiol exerce efeito vasodilatador atuando por meio da regulação da produção de substâncias vasoativas derivadas do endotélio (como o óxido nítrico) ou exercendo efeito direto na musculatura lisa vascular (RUBANYI et al., 2002). Evidências demonstram que o $17 \beta$-estradiol atua como protetor contra o processo inflamatório vascular e que também é responsável por reduzir as taxas de lipoproteínas de baixa densidade (LDL) que conhecidamente são importantes contribuintes para a aterogênese vascular (WHITE et al., 2001). Outro fato relevante é que o $17 \beta$-estradiol promove angiogênese (RUBANYI et al., 2002) e modifica a expressão de $\beta$-adrenoceptores nas vias aéreas (CHANDLER et al., 1987). Todas estas evidências adquirem importância adicional no contexto da asma enquanto doença crônica, visto que a perda da qualidade da função pulmonar ocorre em decorrência do remodelamento tecidual das vias aéreas.

Desta forma, estudos sobre envolvimento dos hormônios sexuais femininos na vigência de inflamação pulmonar crônica de origem alérgica, como ocorre na asma, são de grande interesse. É notável que não existam estudos avaliando o envolvimento dos HSF com o remodelamento das vias aéreas na asma.

No que tange a inflamação pulmonar aguda, estudos realizados por Ligeiro de Oliveira (2004), indicaram que o estrógeno tem efeito modulador na inflamação alérgica pulmonar em ratas. Neste modelo, ratas são submetidas à remoção bilateral dos ovários $(\mathrm{OVx})$ e sensibilizadas com ovoalbumina (OVA) em 1, 3, 7 e 14 dias após a ovariectomia. O modelo de sensibilização e desafios inalatórios com OVA é amplamente utilizado e classicamente representa um bom modelo de alergia pulmonar. Tais grupos são identificados respectivamente como: OVx-1, OVx-3, OVx-7, OVx-14. Em todos os grupos OVx, 
decorridos 14 dias da sensibilização, os animais são submetidos ao desafio antigênico (broncoprovocação por aerossol de OVA). Desta forma, neste modelo, os grupos OVx diferiram quanto aos respectivos níveis de HSFs circulantes no momento de sua sensibilização com OVA, todavia, no momento do desafio com OVA todos estão com 14 dias de sensibilização. A remoção dos ovários reduz os níveis circulantes de estrógenos e de progesterona de tal sorte que a sensibilização com OVA passa a sofrer interferência e ocorre a modificação da magnitude da resposta alérgica pulmonar subseqüente. De fato, a variação dos níveis circulantes hormonais no período de sensibilização parece mediar um efeito dual (ora aumento, ora redução) nos eventos que compõem a inflamação alérgica pulmonar, tais como a desgranulação de mastócitos, a expressão de moléculas de adesão e a atividade funcional de fagócitos pulmonares e de células da medula óssea (DE OLIVEIRA et al., 2004).

No grupo OVx-1 observou-se que os níveis de estradiol e de progesterona no momento da sensibilização foram próximos aos encontrados no estro (valores de referência). Decorridos 7 dias, no período do reforço antigênico, os valores de estradiol haviam reduzido para níveis compatíveis com o diestro (sendo que os de progesterona se mantiveram próximos aos do proestro). Na fase da broncoprovocação, os valores de concentração de estrógeno e de progesterona estavam em níveis baixos, compatíveis com os do diestro e proestro, respectivamente. Com respeito ao grupo $\mathrm{OVx}-7$, os dados indicaram que todo o processo de imunização, reforço e broncoprovocação foram conduzidos com níveis de estradiol bem abaixo dos encontrados na fase de diestro do ciclo estral das ratas. Com respeito a progesterona, os dados mostraram que na sensibilização dos animais, seus níveis estavam próximos a fase de estro, sendo que os demais períodos (reforço, desafio e experimento) seus níveis estavam próximos ao proestro (LIGEIRO DE OLIVEIRA et al., 2010).

Observou-se que no grupo OVx-1, ocorre aumento da inflamação alérgica pulmonar em ratas (LIGEIRO DE OLIVEIRA et al., 2004). Por outro lado, n grupo OVx-7, observa-se inflamação alérgica pulmonar cuja intensidade é significativamente reduzida. A dualidade dos efeitos dos HSFs sobre a magnitude da inflamação alérgica pulmonar parece depender do período de tempo decorrido entre a ovariectomia e a sensibilização dos animais com ao antígeno (DE OLIVEIRA et al., 2004, LIGEIRO DE OLIVEIRA et al., 2010). Estes estudos puderam ser interpretados como modelos representativos da asma pré-menstrual $(\mathrm{OVx}-1)$ ou da asma na pós-menopausa (OVx-7).

Nesse contexto é possível supor existência de importante interação dos hormônios sexuais femininos com o desenvolvimento da inflamação alérgica pulmonar. A avaliação de ativação de mastócitos do grupo OVx-7 mostrou que ocorre redução significativa 
em suas taxas de desgranulação após a exposição ao antígeno. Verifica-se ainda, diferença significativa entre a magnitude de desgranulação dos mastócitos dos animais do grupo OVx-1 (maior) quando comparada com a do grupo OVx-7 (menor).

Estudos realizados por Riffo-Vasquez revelaram que em modelo murino de inflamação pulmonar aguda, os HSF também estão envolvidos com a modulação da reatividade das vias aéreas (RIFFO-VASQUEZ et al., 2007). Especificamente no grupo OVx-7 observou-se significativa redução dos mesmos parâmetros inflamatórios e diminuição da reatividade das vias aéreas in vivo reforçando a hipótese de que a significativa diminuição dos níveis circulantes dos hormônios gonadais femininos pode determinar uma diminuição do processo inflamatório pulmonar. Vale lembrar que o tratamento de animais intactos com tamoxifeno e outros moduladores de receptores de estrógenos mimetizam os efeitos da remoção dos ovários nos animais alérgicos (LIGEIRO DE OLIVEIRA et al., 2004).

Baseados nestes fatos, Ligeiro de Oliveira decidiu também investigar se a ovariectomia afetaria a quantificação de células Treg em órgãos linfoides centrais e periféricos, como o timo, baço e linfonodos. Utilizando o modelo de inflamação alérgica aguda em camundongos BALB/C sensibilizados após 7 dias de ovariectomia (OVx7), os experimentos mostraram que na ausência de HSF ocorre aumento da expressão de Tregs na periferia (linfonodos). Não foram observados decréscimos da população desta célula nos órgãos linfóides centrais em comparação com animais falso-operados. Assim, os dados indicam a possibilidade de uma resposta adaptativa periférica quanto a expressão destas células por influencia da ausência hormonal. Em paralelo, foram mensuradas as citocinas IL-4, IL-5, IL-13 e IL-17 e o aumento da expressão de Tregs estava associado à diminuição na quantificação destas citocinas em explantes pulmonares dos animais ovariectomizados (LIGEIRO DE OLIVEIRA et al., 2013).

Em modelo utilizando camundongos fêmeas C57BLACK/6, nosso grupo verificou que a ovariectomia prevenia o aumento de células inflamatórias no LBA no grupo OVx-7 quando submetidas a 10 desafios (10-D) alérgicos, sendo 3 deasfios alérgicos inalatórios por semana (Dissertação de mestrado SOARES-RODRIGUES, 2010). Neste mesmo modelo, vefificou-se que a ovariectomia prevenia o aumento de IL-5 provocado pelos desafios alérgicos crônicos e que o tratamento com estrógeno no grupo OVx-7 restaurava os níveis de IL-5. O número de linfócitos e macrófagos são aumentados pelos desafios alérgicos crônicos e a ovariectomia destes animais (OVx-7) impede esta elevação. Já a quantificação de eosinófilos e neutrófilos se eleva no grupo sham OVx alérgico e é nula no grupo OVx alérgico 10-D.

Estudos envolvendo a avaliação do recrutamento de células inflamatórias, a quantificação de citocinas e a determinação da expressão de moléculas de adesão após 
indução de inflamação pulmonar alérgica aguda em ratas e camundongos fêmeas $\mathrm{OVx}$ revelam que os hormônios sexuais femininos circulantes desempenham um papel na alergia pulmonar. No entanto, a influência dos HSF em aspectos fundamentais da inflamação crônica, como o remodelamento, a reatividade das vias aéreas e mecânica pulmonar, carece de maior exploração. 


\section{JUTIFICATIVA}

$\mathrm{Na}$ asma o remodelamento das vias aéreas ocupa lugar de destaque. Nesse sentido, a investigação do papel dos HSF no componente estrutural da inflamação pulmonar (remodelamento) se reveste de importância adicional. Tendo em vista que já observou-se a redução dos parâmetros inflamatórios em modelo com 10 desafios alérgicos em camundongos, resolvemos avaliar a influencia dos HSF no remodelamento pulmonar e na reatividade das vias aéreas.

Pretende-se com os estudos propostos, avaliar que tipo de influência (protetora ou indutora) os HSF exercem no processo alérgico crônico visto que suas ações inflamatórias/antiinflamatórias ainda são alvo de discussão. 


\section{OBJETIVOS}

$\rightarrow$ Estudar os efeitos da ovariectomia no desenvolvimento do remodelamento das vias aéreas em modelo de inflamação pulmonar alérgica crônica

$\rightarrow$ Determinar o papel dos hormônios sexuais na reatividade ex vivo das vias aéreas nesse modelo.

$\rightarrow$ Investigar alguns dos mecanismos que participam das alterações estruturais e funcionais do pulmão ocorridas durante a inflamação pulmonar alérgica crônica, na presença ou ausência de HSFs.

$\rightarrow$ Verificar se existem repercussões da influencia dos HSFs na inflamação pulmonar crônica para a função ventilatória dos pulmões. 


\section{MATERIAIS E MÉTODOS}

\subsection{Animais}

Foram utilizados camundongos da linhagem C57Black/6, fêmeas, adultas (com idade entre 45-60 dias) e peso médio entre 20 e 30g, provenientes do Biotério do Departamento de Farmacologia do Instituto de Ciências Biomédicas da USP. Os animais foram mantidos em ciclo claro/escuro de $12 \mathrm{~h}$ em condições padrão de alimento e água ad libitum. Este estudo foi aprovado pela Comissão de Ética em Experimentação Animal do ICB-USP (No. do protocolo da aprovação da comissão de ética animal-USP/ICB: 101, fls.49 do livro 2 de 22.10.2007).

\subsubsection{Grupos de estudo}

Os animais foram divididos em cinco grupos experimentais, a saber:

- Grupo basal: composto por fêmeas não manipuladas.

- Grupo sham OVx-alérgico: animais falsamente-operados e submetidos ao protocolo de sensibilização e desafios alérgicos.

- Grupo OVx-alérgico: animais ovariectomizados (OVx) e submetidos ao protocolo de sensibilização e múltiplos desafios alérgicos (9 ou 21 desafios).

- Grupo OVx-alérgico+P: animais OVx alérgicos, que receberam injeção de $200 \mu \mathrm{g} / \mathrm{kg}$ de progesterona hidrossolúvel (medroxiprogesterona acetato) de ação prolongada por via intra-muscular em dose única no dia anterior à sensibilização com OVA.

- Grupo OVx-alérgico+E: animais OVx Alérgicos que receberam reposição de $17 \mu$ estradiol hidrossolúvel na dose de $280 \mu \mathrm{g} /$ dia por via subcutânea administrada 4 horas antes da sensibilização, do reforço da sensibilização (booster) e de cada desafio alérgico.

O número de animais em cada grupo experimental $(\mathrm{N})$ variou de 6 a 10 indivíduos..

\subsubsection{Tratamentos farmacológicos}

O grupo OVx + E recebeu tratamento com $17 \beta$-estradiol $(280 \mu \mathrm{g} / \mathrm{Kg}$, s.c. $) 4$ h antes da sensibilização ou de cada desafio inalatório com OVA. O grupo $\mathrm{OVx}+\mathrm{P}$ recebeu tratamento com progesterona $(200 \mu \mathrm{g} / \mathrm{Kg}$, im.) em dose única no dia anterior à sensibilização. Como 
controle, os animais receberam pela mesma via, o diluente do estradiol (óleo de milho) ou da progesterona (PBS).

\subsubsection{Ovariectomia}

Os animais foram anestesiados com cetamina $(0,1 \mathrm{mg} / \mathrm{g})$ e xilazina $(0,02 \mathrm{mg} / \mathrm{g})$ por via intraperitonial. Realizou-se com tricotomia e antissepsia da parede abdominal com álcool iodado $(3 \%)$ e posterior incisão mediana da parede abdominal. Após a identificação dos ovários, realizou-se a ligadura de seus pedúnculos e em seguida a ressecção dos tecidos ovarianos. A parede abdominal foi fechada em dois planos com sutura contínua com fio Polyocot (algodão) tamanho 4,0. Como controle, foram utilizados camundongos fêmeas igualmente manipulados sem, no entanto, haver a ressecção dos ovários (falso-operados: sham-OVx Alérgicos). Animais não manipulados (naïve) foram utilizados para obtenção de valores e parâmetros basais. Após a cirurgia foi administrado pentabiótico (540mg/kg, im).

\subsubsection{Validação da ovariectomia}

O sucesso da ovariectomia foi avaliado pela detecção do peso do útero e pela análise do lavado vaginal dos animais. Decorrido o tempo do protocolo do estudo, os animais foram anestesiados com a solução de cetamina/xilazina descrita anteriormente e sob anestesia profunda a eutanásia foi realizada por dessangramento da aorta abdominal. Os animais tiveram os úteros removidos e seus pesos foram determinados em balança analítica. $\mathrm{O}$ padrão morfológico das células presentes no lavado vaginal (LV) foi identificado. Para tanto, um conta-gotas contendo solução salina tamponada com fosfatos (PBS - phosphate buffered saline) era introduzido na vagina e o lavado retirado. O LV era colocado em lâmina de vidro e em seguida cobertos com $5 \mu 1$ de azul de metileno (5\%). Após homogenização com a ponta da lamínula, o LV era levado ao microscópio ótico e observado. Somente as fêmeas ovariectomizadas identificadas na fase de "diestro" de seu ciclo hormonal e com redução da massa uterina, eram utilizadas no estudo.

Grupos de camundongos fêmeas foram sensibilizados 7 dias após a OVx. Como controle foram utilizadas camundongos fêmeas falsamente-operados (sham-OVx). Decorridos 21 dias de sensibilização os animais foram brocoprovocados, sacrificados após 42 dias e o peso do útero determinado. Os dados representam média \pm epm de 5 animais. ${ }^{*} \mathrm{p}<0,05 \mathrm{em}$ relação ao grupo sham-OVx alérgico. Paralelamente, analisamos os tipos de células presentes 
no lavado vaginal para determinação da fase do ciclo estral. $\mathrm{O}$ ciclo estral consiste nas mudanças fisiológicas periódicas induzidas por hormônios reprodutivos na maioria das espécies dos mamíferos placentais. O ciclo estral dos camundongos tem duração de 4 a 5 dias, e caracteriza-se por 4 fases bem típicas: proestro, estro, metaestro e diestro. (LONG ; EVANS, 1992). A ovulação inicia-se no proestro e termina no estro. O proestro começa com a fase folicular do ovário que culmina com o estro (cio). O metaestro e o diestro caracterizamse pela fase luteínica do ovário. O perfil celular encontrado nas lâminas de lavado vaginal dos camundongos permite identificar em que fase de seus ciclos hormonais eles se encontram.

As fotomicrografias a seguir referem-se a estudos previamente realizados em nosso laboratório, nos quais podemos observar um paralelo entre as fases do ciclo estral e as características celulares encontradas no lavado vaginal. A redução da concentração dos hormônios sexuais induzida pela ovariectomia culminou com a indução e manutenção do diestro, no qual se observa predominância de leucócitos no lavado vaginal. No metaestro (figura 4 - fotomicrografia A) caracterizado pelos baixos níveis de estrógeno e progesterona há uma mescla de células anucleadas, nucleadas e leucócitos. No proestro (figura 4fotomicrografia B), período em que a atividade folicular é mais alta, encontramos altos níveis de estrógeno e baixos de progesterona. Nesta fase o esfregaço vaginal é composto por células nucleadas. $\mathrm{O}$ diestro (figura 4- fotomicrografia $\mathrm{C}$ ), fase associada com a atividade do corpo lúteo, é caracterizado pelos baixos níveis de estrógeno e elevadas concentrações de progesterona. Nele, o esfregaço vaginal é constituído basicamente por leucócitos. Por fim, no estro (figura 4 - fotomicrografia D), os níveis de progesterona começam a diminuir e os de estrógeno a aumentar. O estro é caracterizado pela presença de células anucleadas no lavado vaginal (LIGEIRO DE OLIVEIRA et al., 2004; SPORNITZ et al., 1999). 


\section{Figura 4 - Fases do ciclo estral}
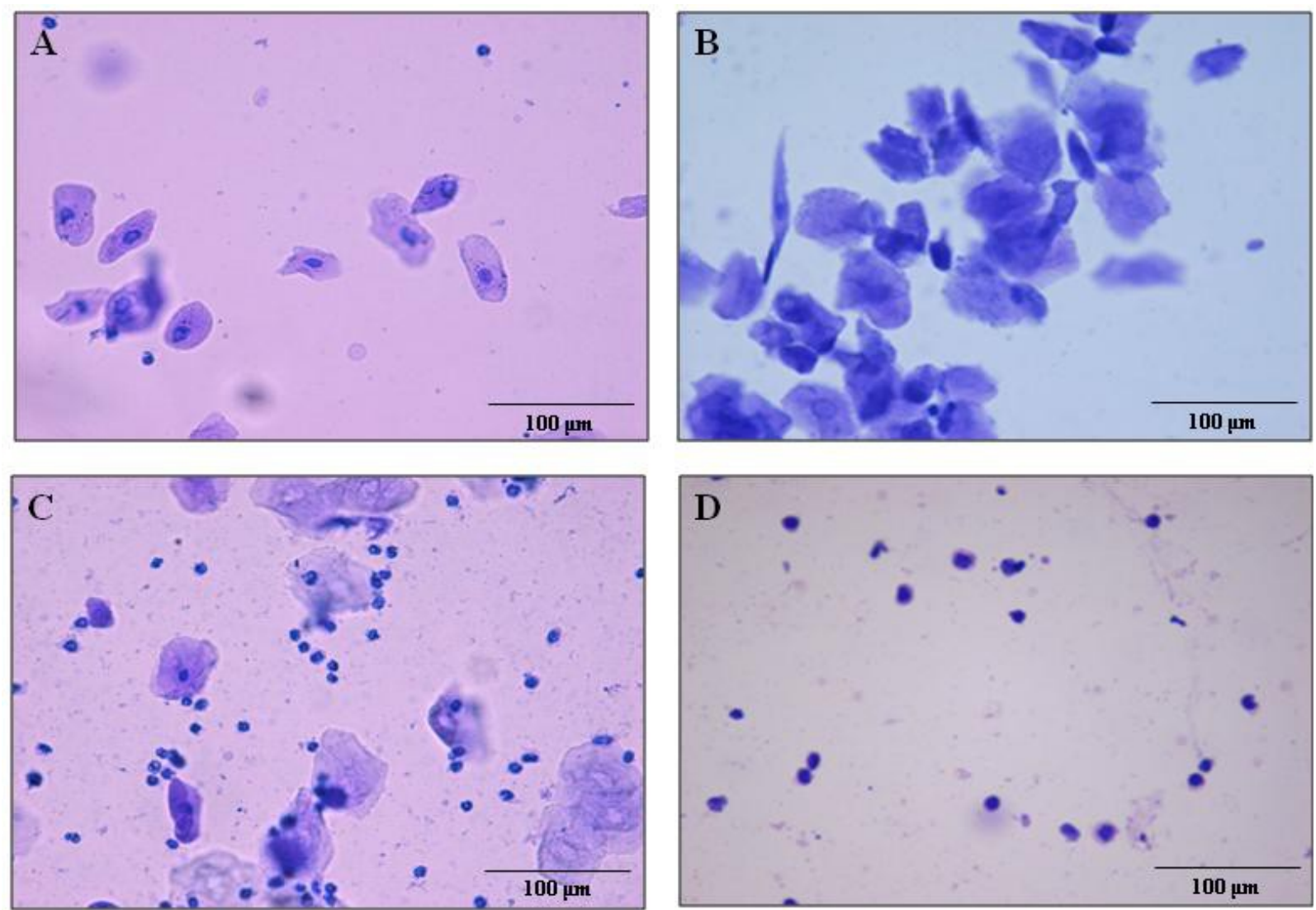

7 dias após a remoção dos ovários

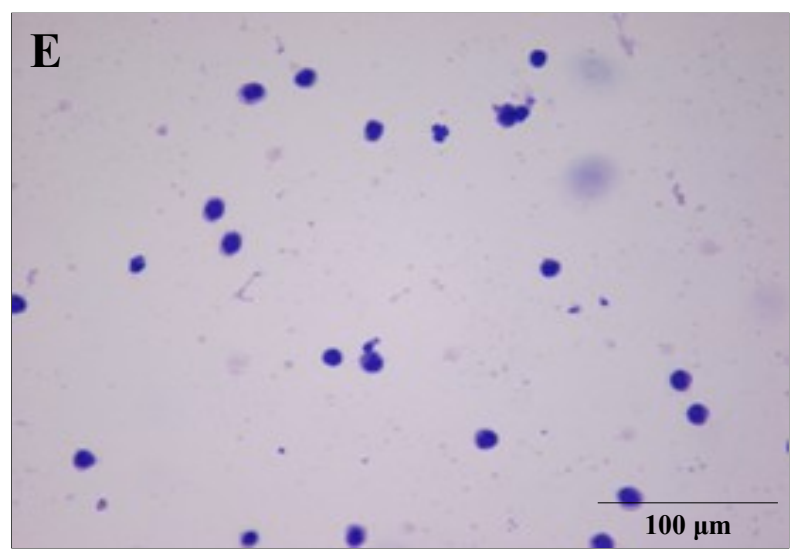

Fotomicrografias das fases do ciclo estral de camundongos fêmeas de um animal OVx7. Em (A) predomínio de células nucleadas em proestro. (B) Predomínio de células anucleadas no estro (C) metaestro, caracterizado por diferentes tipos celulares e em (D) diestro, fase em que são encontrados apenas leucócitos. Em (E) está representada a fotomicrografia do lavado vaginal de um animal 7 dias após a remoção dos ovários, que culminou na indução e manutenção da fase de diestro, onde há predominância de leucócitos. As células foram coradas com azul de metileno (5\%) e analisadas em microscópio óptico comum em aumento de 40x. 


\subsubsection{Sensibilização e broncoprovocação in vivo}

Os animais receberam 10 $\mu \mathrm{g}$ de OVA grau II dissolvidas em alúmen $(10 \mathrm{mg})$ inoculado por via subcutânea no dorso (dia zero). Decorrida uma semana (dia 7) os animais recebiam um reforço (booster) na mesma forma e dose. A partir do $14^{\circ}$ dia da imunização primária (dia zero), os animais foram broncoprovocados através de inalação de solução de ovoalbumina (OVA 1\%). Para tanto, os animais foram colocados em uma caixa plástica fechada $(18,5 \mathrm{~cm} \mathrm{X}$ 18,5 cm X 13,5 com), acoplada a um nebulizador ultra-sônico ( ICEL®) com capacidade de produzir névoa com partículas entre 0,5 a 1,0 micron. As sessões de inalação (desafios) foram realizadas por 15 min. cada uma. Os animais foram submetidos a 3 desafios por semana durante 3 ou 7 semanas seguidas, recebendo nove ou vinte e um desafios respectivamente. Os experimentos foram conduzidos cinco dias após o último desafio. A ilustração a seguir demonstra o esquema de manipulação dos grupos experimentais. Para os animais submetidos a 21 desafios, foi mantido o mesmo esquema, porém durante cinco semanas ao invés de três.

\section{Figura 5 - Delineamento do protocolo experimental}

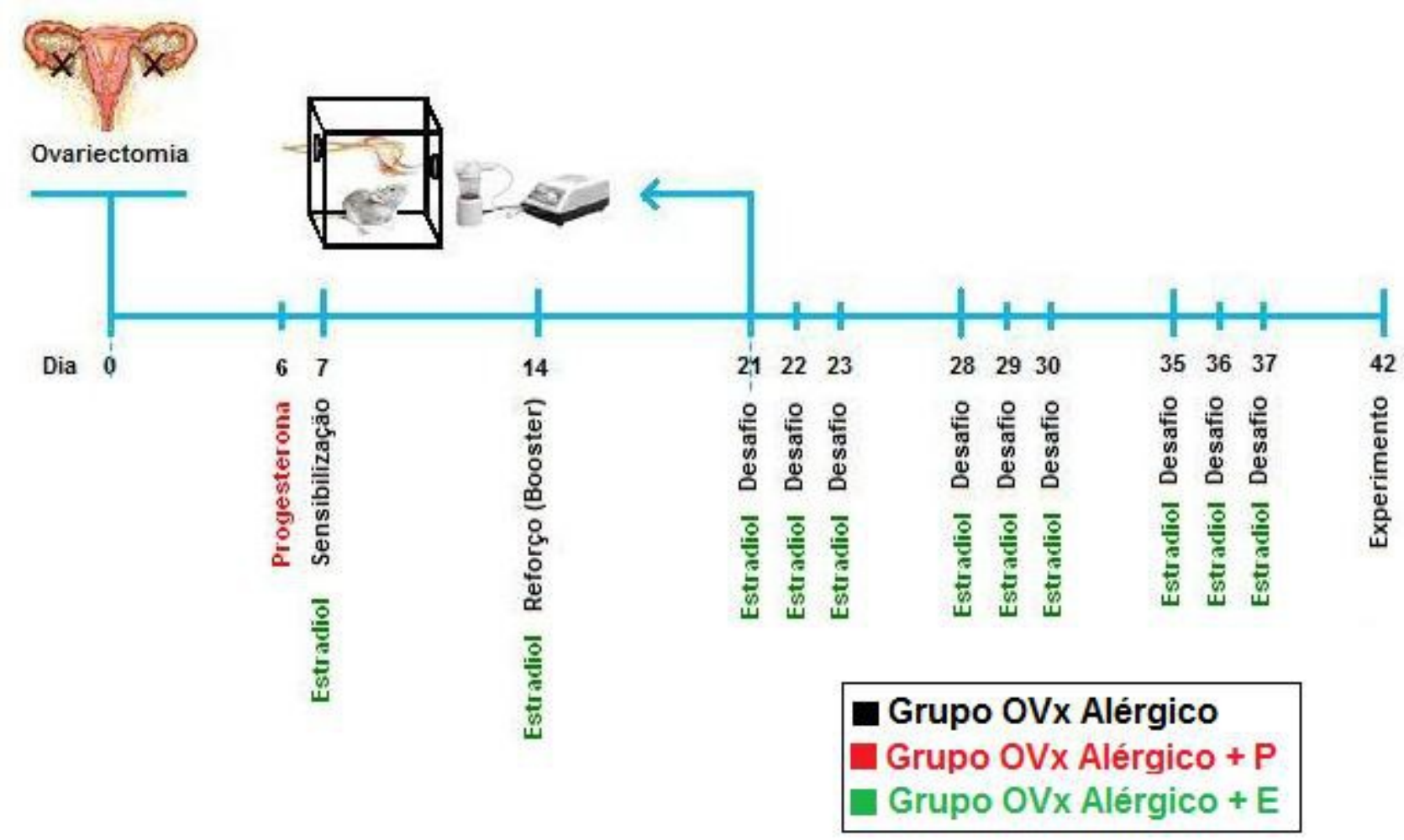

Nos animais do grupo Sham, no lugar da ovariectomia (dia zero) ocorre cirurgia abdominal sem remoção ovariana. Nos animais submetidos a 21 desafios, o esquema continuaria com três desafios por semana durante mais quatro semanas (total de sete semanas) respeitando-se os mesmos intervalos até o experimento ser feito no $77^{\circ}$ dia. 


\subsection{Avaliação do remodelamento das vias aéreas}

Os animais foram anestesiados como descrito anteriormente, e submetidos à excisão do lobo inferior do pulmão esquerdo durante a fase respiratória de expiração para manutenção do volume residual pulmonar. Após isto, realizou-se a eutanásia como já descrito anteriormente. Os tecidos pulmonares foram fixados em formol a $10 \%$ e os cortes foram obtidos utilizando-se micrótomo, com seções seriadas de $3 \mu \mathrm{m}$ de espessura para a confecção das lâminas para visualização em microscopia ótica. Todas as lâminas receberam coloração de hematoxilina-eosina (H.E.). Para cada animal de cada grupo foram obtidos ao menos dois cortes para as colorações especiais (picrussirius red e P.A.S.).

A avaliação do remodelamento das vias aéreas foi realizada de duas maneiras: pelo estudo de parâmetros diretos e pelo estudo de parâmetros indiretos do remodelamento dos bronquíolos distais.

Para avaliação dos parâmetros diretos do remodelamento realizamos a quantificação de fibras colágenas bronquiolares, quantificação do aumento do epitélio de revestimento das vias aéreas e quantificação do aumento das fibras musculares lisas peri-bronquiolares. Para avaliação dos parâmetros indiretos do remodelamento realizamos a quantificação de muco não-extrusado (que demonstra indiretamente a hiperplasia das células produtoras de muco) e a avaliação da razão entre a área total da via aérea medida a partir da membrana basal e a área total da luz da via aérea. Chamaremos esta razão de índice de diminuição luminal dos bronquíolos distais, pois quanto maior esta razão, mais diminuído estará o calibre da via aérea. Esta quantificação demonstra indiretamente o fenótipo adquirido pelas vias aéreas distais mesmo na ausência de estímulo alérgico. As avaliações foram realizadas por meio da análise colorimétrica das imagens de microscopia ótica.

\subsubsection{Avaliação de colágeno nos bronquíolos distais}

As lâminas foram coradas com "Picrosirius red" para a marcação das fibras de colágeno e posteriormente levadas ao microscópio ótico (Zeiss Axioplan ${ }^{\circledR}$ ) com câmera de vídeo acoplada. As imagens foram transferidas ao computador e digitalizadas pelo software (NSis ${ }^{\circledR}$ v.9.0).

As imagens digitais foram submetidas à análise colorimétrica pelo software ImagePro-Plus ${ }^{\circledR}$ (versão 4.5.0.29®). Para a quantificação das áreas representativas de colágeno as 
regiões das lâminas coradas pelo corante descrito acima foram marcadas, e contabilizadas digitalmente. Cada campo digitalizado apresenta uma resolução de 640 pontos na horizontal por 480 pontos na vertical e 24 bits de cores (16 milhões de cores). O campo digitalizado corresponde a uma área de 395 micra de largura por 300 micra de altura na imagem real.

Foram analisadas 06 vias aéreas por lâmina. Para coloração de colágeno foi determinado um filtro pré-montado com base em um número representativo de fotos, marcando as áreas positivas de colágeno (coradas por picrosirius red). Este filtro é utilizado em todas as leituras de um mesmo grupo. Para medição das dimensões das vias aéreas foi delimitada a área de superfície de sua parede e o comprimento da membrana basal no aumento de 40x. O percentual de fibras colágenas foi determinado pela razão entre a área de positividade (áreas coradas para colágeno) multiplicada por 100 e a área de superfície total da via aérea correspondente. Os resultados são expressos em porcentagem em relação à área total da via aérea analisada.

\subsubsection{Avaliação da presença de muco nos bronquíolos distais}

Para coloração especial do muco nas lâminas foi utilizado o ácido periódico de Schiff (PAS). O muco quantificado nas vias aéreas corresponde ao muco não-extrusado, ou seja, o muco presente nos ácinos conhecidos como células goblet (células caliciformes produtoras de muco). O muco presente na luz das vias aéreas não foi quantificado por conta de não se conhecer sua procedência exata, o local onde teria sido produzido. A quantificação de muco seguiu o mesmo padrão de fixação, observação e análise de imagens realizada para a quantificação de fibras colágenas. Também foram analisadas 06 vias aéreas por lâmina.

\subsubsection{Avaliação da camada de músculo liso peribronquiolar}

Para a quantificação do músculo liso peribronquiolar nas lâminas não houve necessidade de coloração especial. Nas lâminas coradas por H.E. a região ocupada pelas fibras musculares lisas foi selecionada e marcada. O percentual de fibras musculares lisas na via aérea foi determinado pela razão entre a área marcada multiplicada por 100 e a medida da área de superfície total da via aérea correspondente. Os resultados são expressos em porcentagem em relação à área total da via aérea analisada. Foram analisadas 06 vias aéreas por lâmina. 


\subsubsection{Avaliação da camada de epitélio respiratório das vias aéreas}

Para a quantificação da camada epitelial das vias aéreas não houve necessidade de coloração especial. Nas lâminas coradas por H.E. a região ocupada pelo epitélio foi selecionada e marcada. O percentual de área ocupada pelo epitélio expiratório foi determinado pela razão entre a área marcada multiplicada por 100 e a medida da área de superfície total da via aérea correspondente. Os resultados são expressos em porcentagem em relação à área total da via aérea analisada. Foram analisadas 06 vias aéreas por lâmina.

\subsubsection{Avaliação morfométrica dos bronquíolos distais}

Realizou-se análise morfométrica dos bronquíolos distais para observação de sua diminuição luminal. Para tanto, mediu-se a área total da via aérea a partir do perímetro de sua membrana basal e dividiu-se pela área da luz da via aérea medida a partir da borda do epitélio respiratório. Os resultados são expressos em unidades arbitrárias e estão ilustrados por graficamente. Quanto maior este quociente, menor é a luz da via aérea correspondente. Foram avaliados um total de seis cortes de bronquíolos periféricos de vias aéreas distais, com diâmetro de até $400 \mu \mathrm{m}$ por lâmina, com uma lâmina para cada indivíduo do grupo (grupos compostos de 6 a 8 animais).

Figura 6 - Representação da diminuição luminal dos bronquíolos distais após remodelamento

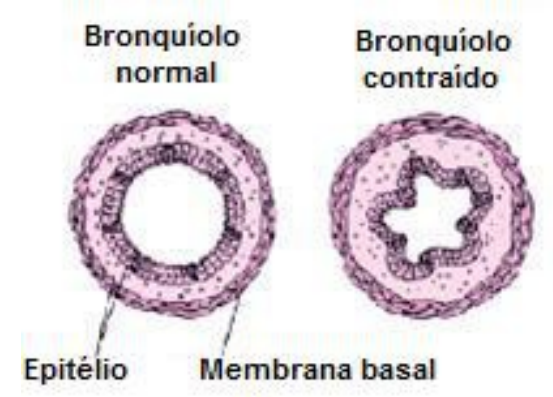

A área total da via aérea é calculada a partir do perímetro de sua membrana basal. A área da luz da via aérea é calculada a partir do perímetro da superfície do epitélio respiratório. Assim, quanto maior a área da luz, maior será a razão entre a área total da via aérea e a área de sua luz. Este valor será utilizado para representar o índice de diminuição luminal da via aérea. Quanto menor o valor encontrado, menor o calibre da via aérea.

\subsection{Estudo ex vivo da traquéia isolada}


Os animais foram mortos como já descrito anteriormente, tendo a seguir o tórax aberto. A traquéia distal foi isolada e o tecido conjuntivo adjacente removido. A seguir, os segmentos de tecido traqueal foram montados para registro isométrico de contrações em cubas para órgão isolado $(15 \mathrm{ml})$ contendo solução de Krebs-Henseleit aerada com 95\% e 5\% $\mathrm{CO} 2$ com a seguinte composição (mM): $\mathrm{NaCl}, 115.0$; KCl, 4.6; CaCl2 2. H20, 2.5; KH2PO4, 1.2; MgSO4. $7 \mathrm{H} 20,2.5$; $\mathrm{NaHCO} 3,25.0$ e glicose 11.0 . O registro de força isométrica foi realizado usando o sistema, POWER LAB ${ }^{\circledR} 4$ sp, utilizando-se o programa LabChart® ${ }^{\circledR}$ 7.3.1 para análise.

Anéis de traquéia foram expostos a uma carga inicial de $0,5 \mathrm{~g}$ e a análise feita a uma DDP de 500mV. Durante o período de equilíbrio (40 minutos), a solução de Krebs-Henseilet foi trocada a cada 10 minutos. Decorrido esse período, a tensão foi reajustada para $0,5 \mathrm{~g}$. A capacidade contrátil (viabilidade tecidual) dos segmentos de tecido foi avaliada substituindo o tampão Krebs-Henseilet por tampão $\mathrm{KCl}$ despolarizante $(60 \mathrm{mM})$. As preparações dos tecidos foram expostas ao $\mathrm{KCl}$ a fim de se avaliar a vitalidade do tecido. Após a avaliação da viabilidade das preparações, o $\mathrm{KCl}$ foi substituído pelo tampão Krebs-Henseilet. Decorridos 20 minutos de equilíbrio, iniciou-se a introdução de concentrações crescentes de metacolina (de 10-6 molar até 10-1 molar) para obtenção de curva concentração-efeito.

\subsection{Quantificação de metaloproteinases de matriz}

Para quantificação das MMPs foi utilizada a zimografia por eletroforese. As amostras de tecido pulmonar foram homogeneizadas por masseração e diluídas em tampão de lise (100mM de Tris- $\mathrm{HCl} \mathrm{pH} 7.5,1 \%$ de desoxicolato de sódio, 1\% de NP40, 150mM de NaCl, $0,1 \%$ de dodecil sulfato de sódio (SDS)) acrescido de inibidores de proteases $(1 \mathrm{mg} / \mathrm{ml}$ peptastina A, 100mM PMSF). Em seguida, os homogenatos foram centrifugados a $14000 \mathrm{G}$ por 10 minutos a $4^{\circ} \mathrm{C}$. Após a centrifugação, o sobrenadante foi coletado e as proteínas quantificadas utilizando-se o método Bradford (BRADFORD, 1976).

Para a eletroforese preparou-se utilizou-se gel com $10 \%$ de acrilamida contendo $0,2 \%$ de gelatina $(1,67 \mathrm{ml}$ de acrilamida/bis 30\%; 2,5 ml de 0,5 M de Tris-HCl pH 6.8; $100 \mu \mathrm{lde}$ SDS 10\%; 5,68 ml de água desionizada e autoclavada; $50 \mu 1$ de APS 10\% e 5 $\mu 1$ de TEMED). Após montado o gel na cuba de eletroforese, as amostras foram diluídas de 1:1 com tampão (2\% SDS, 60mM Tris pH 6,8, 30\% de glicerol e 0,01\% de azul de bromofenol), e colocadas em banho-maria a $55^{\circ} \mathrm{C}$ por 3 a 5 minutos. 
A eletroforese foi realizada em sistema resfriado SDS -PAGE com voltagem constante. Depois da eletroforese, retirou-se e transferiu-se o gel para um recipiente contendo 2,5\% de Triton $\mathrm{X}$ - 100 diluído em água desionizada para remoção do SDS e renaturação das proteínas. Procedeu-se à duas lavagens de 15 minutos cada. Em seguida, descartou-se a solução de Triton e incubou-se o gel em solução tampão reveladora (50mM de Tris pH 8.8, $5 \mathrm{mM} \mathrm{CaCl} 2,0,02 \% \mathrm{NaN} 3$ ) por 16 a 20 horas a $37^{\circ} \mathrm{C}$.

Após a incubação em solução reveladora, fixou-se o gel em solução descorante (40\% metanol, 10\% de ácido acético, 40\% de água) por 15 minutos sob agitação e à temperatura ambiente. Descartou-se a solução descorante e corou-se o gel com Coomassie Brilliant Blue R-250 (Amersham $\left.{ }^{\circledR}\right)$ por 3 horas. Em seguida, descartou-se o corante e se descorou-se o gel com solução descorante. As metaloproteinases ativas foram identificadas como bandas claras de lise em fundo azul. A MMP-2 apresenta pesos moleculares de 72 e $62 \mathrm{kDa}$ e a MMP-9 de 92 e $88 \mathrm{kDa}$, para o zimogênio e a forma ativa, respectivamente. Após o processo, o gel foi escaneado e sua imagem digitalizada. A avaliação das bandas é realizada por análise colorimetrica da imagem através do software Image Pro Plus ${ }^{\circledR}$.

Para se confirmar se as bandas de lise observadas nos zimogramas são devido à ação de metaloproteinases de matriz foram necessários controles-negativos. MMPs dependem de cálcio e metais pesados (zinco) para exercer sua atividade enzimática. Dessa forma, adicionou-se $5 \mathrm{mM}$ de EDTA (quelante de cálcio) ao tampão de revelação dos zimogramas. O EDTA inibiu a formação de bandas gelatinolíticas claras observadas nos zimogramas.

\subsection{Avaliação da mecânica pulmonar in vivo}

Os animais foram anestesiados com cetamina $(100 \mathrm{mg} / \mathrm{kg})$ e xilazina $(20 \mathrm{mg} / \mathrm{kg})$ por via intraperitoneal. Após anestesia foi realizada traqueotomia e no orifício da traquéia foi introduzida uma cânula metálica (18 Gauge) fixada ao ventilador mecânico (FlexiVent, SCIREQ ${ }^{\circledR}$, Montreal, Quebec, Canadá). Os animais foram então submetidos à ventilação mecânica de volume corrente de $10 \mathrm{ml} / \mathrm{kg}$ e freqüência respiratória (FR) de 450 ciclos/minuto. A PEEP (pressão positiva no final da expiração) foi mantida em $3 \mathrm{cmH} 2 \mathrm{O}$.

Após cinco minutos de ventilação, os pulmões eram insuflados até uma pressão de 30 cmH2O e mantidos nessa pressão por 3 segundos, a fim de promover a abertura de regiões atelectasiadas (manobra de recrutamento alveolar). A manobra era repetida por duas vezes com intervalo de 30 segundos entre elas antes de cada nebulização. 
O protocolo de manobras de ventilação mecânica era programado no sistema, de forma que o equipamento repetia exatamente o mesmo padrão para todos os animais. Mediu-se os padrões de resistência e elastância pulmonares totais em condições basais (sem estímulo farmacológico), após nebulização de controle com PBS (phosphate buffered saline) após nebulização com MCh $50 \mathrm{mg} / \mathrm{mL}$ e após nebulização com MCh $100 \mathrm{mg} / \mathrm{mL}$. Ao total eram avaliadas 16 medições de resistência e elastância pulmonares para cada animal. As nebulizações eram realizadas via cânula intra-traqueal durante 10 segundos, por um micronebulizador de bombeamento (Aeroneb ${ }^{\circledR}$, Aerogen). A coleta dos dados de resistência e elastância foram realizadas sempre 15 segundos após o término de cada nebulização. Entre uma concentração e outra de MCh havia um intervalo de 5 minutos.

Para o cálculo dos parâmetros de resistência do sistema respiratório (R_rs) e de elastância do tecido pulmonar (E_rs) foi considerado o modelo unicompartimental que utiliza a equação do movimento no tempo, tal como postula a fórmula abaixo:

$$
\mathrm{P}=\mathrm{R} \_ \text {rs. } \mathrm{V}^{\wedge \prime}+\mathrm{E} \_ \text {rs. } \mathrm{V}+\mathrm{P} \_0
$$

onde $\mathrm{P}$ é a pressão na entrada das vias aéreas, $\mathrm{R} \_$rs é a resistência do sistema respiratório, $\mathrm{V}^{\wedge}$ é o fluxo calculado pela derivada do volume, E_rs é a elastância do tecido pulmonar, V é o volume e P_0 é a constante de correção de erros da capacidade residual funcional.

Findo o experimento, o animal foi submetido à eutanásia por meio da secção da aorta abdominal (dessangramento) e então desconectado do aparelho. Os dados foram capturados e analisados pelo software flexiVent, versão 5.2.

\subsection{Drogas utilizadas}

Droga: Ketamina

Nome comercial: Anasedan ${ }^{\circledR}$

(CEVA SANTE ANIMALE - Avenue de La Ballastière, 33500 Libourne, França)

Droga: Xilazina

Nome comercial: Dopalen ${ }^{\circledR}$.

(CEVA SANTE ANIMALE - Avenue de La Ballastière, 33500 Libourne, França)

Droga: Benzilpenicilina benzatina 600.000 UI, Benzilpenicilina procaína 300.000 UI, Benzilpenicilina potássica $300.000 \mathrm{UI}$, Sulfato de diidroestreptomicina base $250 \mathrm{mg}$, Sulfato de estreptomicina base sulfato $250 \mathrm{mg}$

Nome comercial: Pentabiótico ${ }^{\circledR}$ 
(PFIZER - Manufacturing Belgium NV Puurs - Bélgica).

Droga: Medroxiprogesterona Acetato

Nome comercial: Depo ${ }^{\circledR P}$ Provera ${ }^{\circledR}$

(PFIZER - Manufacturing Belgium NV Puurs - Bélgica).

Droga: $17 \beta$-estradiol

Nome comercial: $\beta$ Estradiol ${ }^{\circledR}$

(SIGMA ALDRICH, Co., Spruce Street, St. Louis, MO 63103, USA 314-771-5765)

Droga: Acetil B metil colina clorido

Nome comercial: Metacolina ${ }^{\circledR}$

(SIGMA ALDRICH, Co., Spruce Street, St. Louis, MO 63103, USA 314-771-5765)

Droga: Hidróxido de Alumínio

Nome comercial: Pepsamar ${ }^{\circledR}$

(SANOFI AVENTIS FARMACEUTICA LTDA, - Indústria Brasileira, Av. Major Magalhães Padilha - SP).

\subsection{Análises estatísticas}

Os dados dos grupos (animas controle, OVx alérgico, sham-OVx Alérgico e tratados) foram submetidos à análise de variância (Two Way ANOVA) seguido do teste NewmanKeuls para comparação dos pares de amostras. As análises estatísticas foram conduzidas utilizando o Software Prisma ${ }^{\circledR}$. Valores de $\mathrm{P}<0,05$ foram considerados significativos.

\section{RESULTADOS}

\subsection{Quantificação da massa uterina após a remoção dos ovários}

Na tabela 1 estão representados os valores obtidos da quantificação da massa uterina de camundongos fêmeas 42 dias após a remoção dos ovários (OVx). Como pode ser observado, a 
massa uterina dos animais do grupo $\mathrm{OVx}$-alérgico reduziu significantemente em relação à dos animais do grupo falsamente operados (sham-OVx-alérgico).

Tabela 1. Massa uterina após a remoção dos ovários.

Grupos

Sham-OVx alérgico

OVx alérgico
Peso do útero (mg)

$50,3 \pm 2,1$

$14,5 \pm 1,0 *$

Grupos de camundongos fêmeas foram sensibilizados 7 dias após a OVx. Como controle foram utilizadas camundongos fêmeas falsamente-operados (sham-OVx). Decorridos 21 dias de sensibilização os animais foram brocoprovocados, sacrificados após 42 dias e o peso do útero determinado. Os dados representam média \pm epm de 5 animais.* $\mathrm{p}<0,05$ em relação ao grupo sham-OVx alérgico.

\subsection{Estabelecimento do protocolo de remodelamento pulmonar}

Primeiramente delineamos o protocolo de desafios alérgicos sequenciais para obter um modelo de inflamação pulmonar crônica que resultasse em evidente remodelamento das vias aéreas.

A princípio submetemos os grupos de animais de experimentação a 21 desafios alérgicos para obter alterações residuais indubitavelmente crônicas. Os parâmetros de remodelamento escolhidos para avaliar este grupo foram a quantificação de colágeno nas vias aéreas e a quantificação de muco extrusado.

Houve remodelamento exuberante, ilustrado por aumento da quantificação de muco extrusado das vias aéreas em relação ao grupo de animais não manipulados - evidenciando que existe proporcional hiperplasia das células produtoras de muco neste tecido e houve aumento significativo da área e colágeno das vias aéreas em relação a animais nãomanipulados. Entretanto, em ambas as análises (muco e colágeno) não se observou diferença significativa entre os grupos alérgicos ovariectomizado e falso-operado (sham OVx-alérgico e o grupo OVx-alérgico).Os resultados das análises podem ser observadas nos gráficos abaixo. 
Figura 7 - Percentual de muco nas vias aéreas em animais submetidos a 21 desafios alérgicos

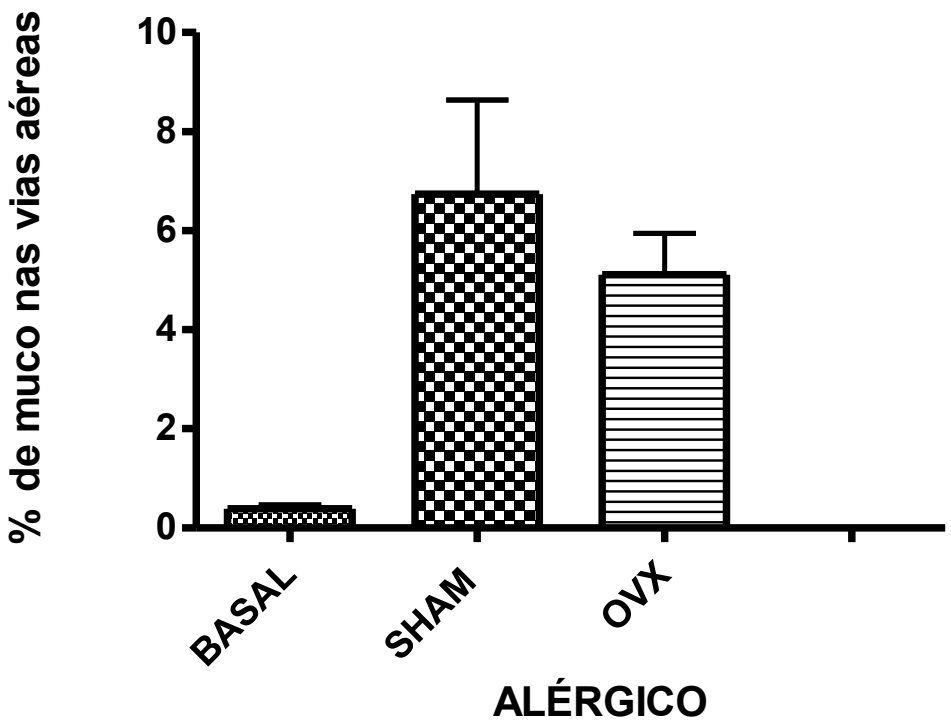

Efeito da ovariectomia sobre o percentual de muco nas vias aéreas em modelo murino de inflamação alérgica pulmonar crônica submetidos a 21 desafios alérgicos. O percentual de muco foi determinado pela quantificação da área de positividade para muco (área corada por PAS) em relação à área total de superfície da via aérea correspondente. Os dados representam a media \pm epm do grupo de animais. $*=$ p $<0.05$ em relação ao grupo basal. (grupos compostos de 6 a 8 animais).

Figura 8- Percentual de colágeno nas vias aéreas de animais submetidos a 21 desafios alérgicos 


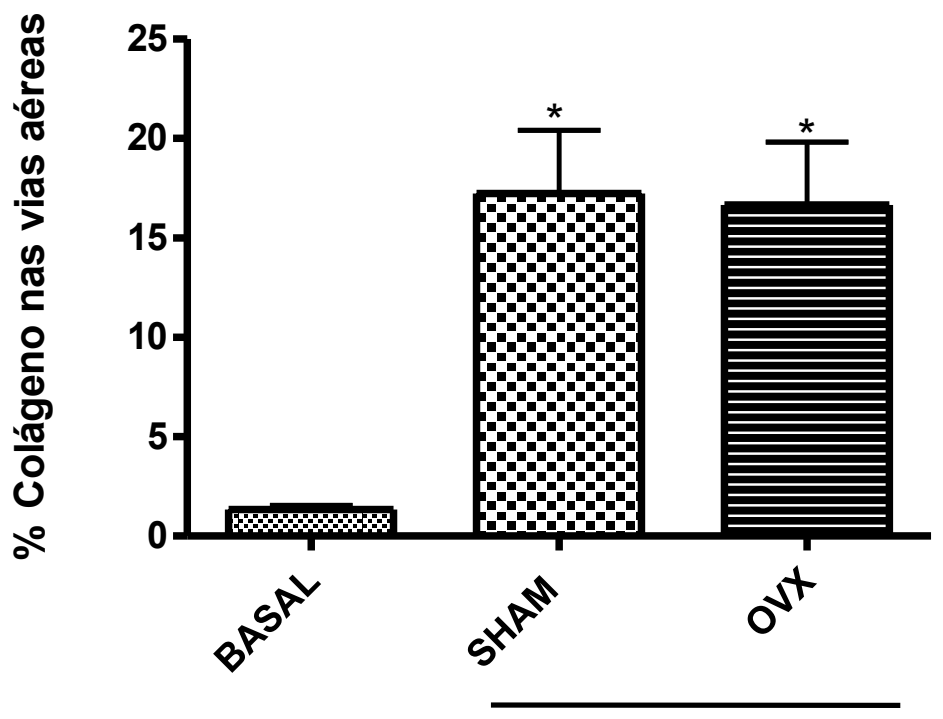

ALÉRGICO

Efeito da ovariectomia sobre o percentual de colágeno das vias aéreas em modelo murino de inflamação alérgica pulmonar crônica submetidos a 21 desafios alérgicos. O percentual de colágeno foi determinado pela quantificação da área de positividade para muco (área corada por picrussirius red) em relação à área total de superfície da via aérea correspondente. Os dados representam a media \pm epm do grupo de animais. ${ }^{*}=\mathrm{p}<0.05$ em relação ao grupo basal. (grupos compostos de 6 a 8 animais).

Embora o remodelamento das vias aéreas tenha ficado bem configurado com 21 desafios alérgicos, notamos que após este grau de remodelamento não existem diferenças entre o grupo alérgico privado de HSFs e o grupo alérgico falso-operado. Assim, diminuímos a quantidade de desafios alérgicos a um nível em que houvesse franco remodelamento dos tecidos das vias aéreas, porém com perceptíveis diferenças entre os grupos, devidas à influencia dos HSFs na inflamação pulmonar crônica. A partir esta observação, optamos por trabalhar com um protocolo experimental de 9 desafios alérgicos sequenciais para avaliar os efeitos da ovariectomia no remodelamento pulmonar, avaliando parâmetros de muco e colágeno e incluindo outros parâmetros de alteração tecidual de origem inflamatória. 


\subsection{Efeitos da ovariectomia sobre a quantificação de muco nas vias aéreas}

Em animais submetidos a 9 desafios alérgicos, observamos que o grupo falsamente operado (sham OVx-alérgico) demonstrou aumento do percentual de muco em relação ao grupo não manipulado (basal). $\mathrm{O}$ grupo alérgico submetido à ovariectomia prévia (OVxalérgico) apresentou muco quantificado em valores percentuais semelhante aos do grupo basal. A figura 9 ilustra o efeito observado.

Figura 9- Percentual de muco nas vias aéreas em animais submetidos à 9 desafios alérgicos

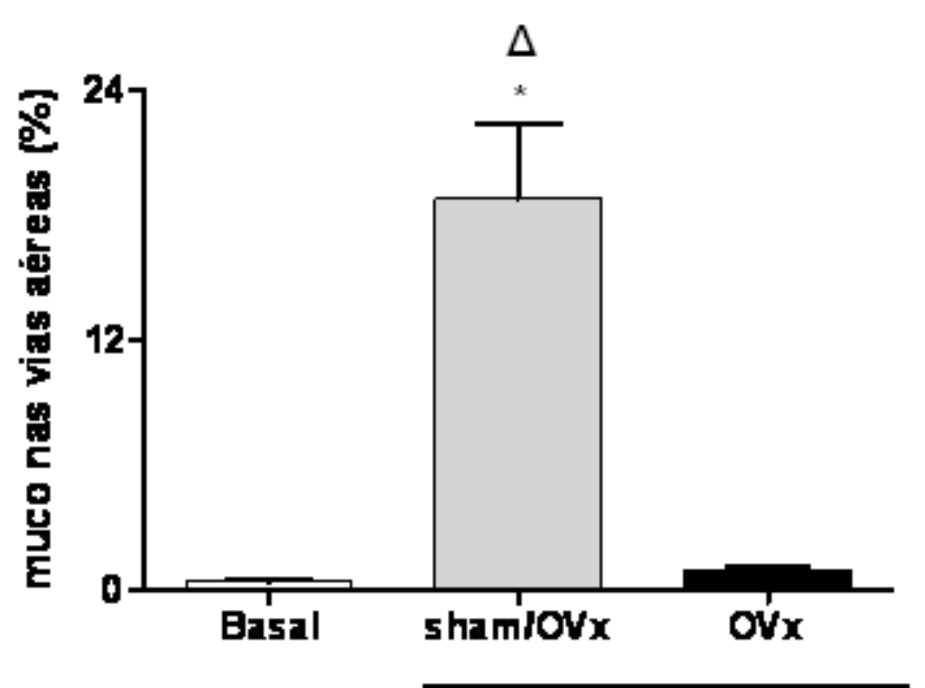

Alérgicos

Efeito da ovariectomia sobre o percentual de muco nas vias aéreas em modelo murino de inflamação alérgica pulmonar crônica com nove desafios alérgicos. O percentual de muco foi determinado pela quantificação da área de positividade para muco (área corada por PAS) em relação à área total de superfície da via aérea correspondente. Os dados representam a media \pm epm do grupo de animais. * = $\mathrm{p}<0.05$ em relação ao grupo basal. $\Delta=\mathrm{p}<0.05$ em relação ao grupo $\mathrm{OVx}$-alérgico (grupos compostos de 6 a 8 animais).

Na figura 10, o painel "A" mostra a quantidade habitual de muco presente em um bronquíolo distal de um animal não-manipulado (grupo basal) corado de rosa por PAS (seta). No painel B observa-se que ocorre grande aumento da quantidade de muco intracelular (seta) 
em um camundongo do grupo sham OVx-alérgico. No painel "C" visualiza-se num animal do grupo $\mathrm{OVx}$ - alérgico quantidade de muco presente nas vias aéreas comparável à dos animais do grupo basal.

Figura 10- Fotomicrografias dos grupos basal, sham OVx alérgico e OVx alérgico corados com P.A.S.

\section{Basal (naïve)}

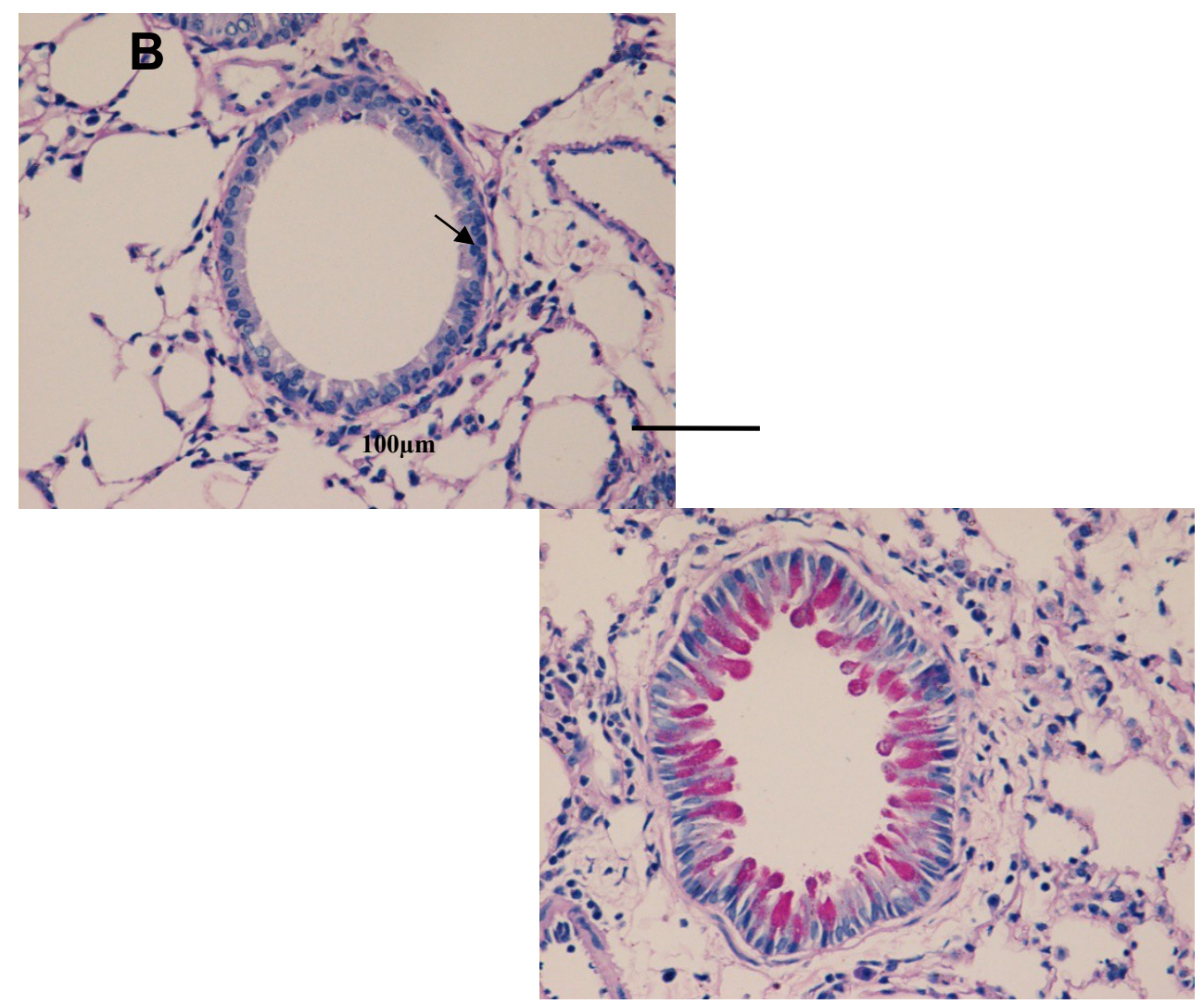

\section{OVx-Alérgico:}

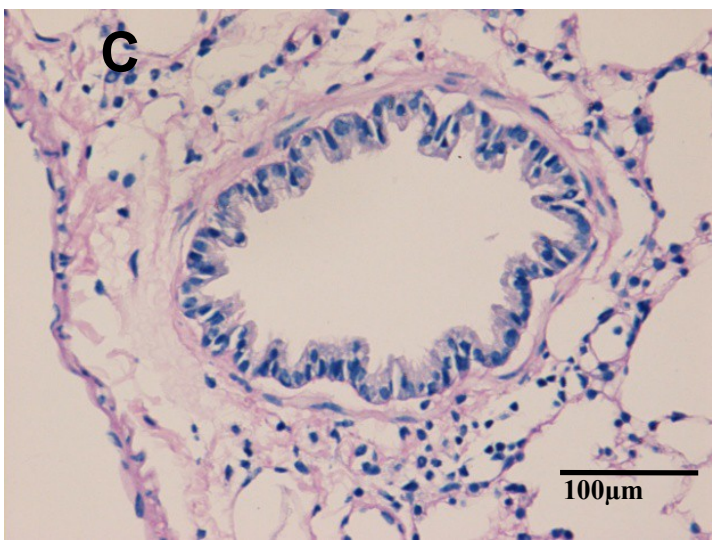


Fotomicrografia de bronquíolos de camundongos fêmeas em modelo de inflamação alérgica crônica no aumento de 40 x. O painel A representa bronquíolo distal de animal do grupo basal (naïve). Painel B mostra bronquíolo distal de animal do grupo alérgico falso-operado (sham OVx-alérgico). O painel $\mathrm{C}$ apresenta bronquíolo distal de animal do grupo ovariectomizado alérgico (OVx-alérgico). A seta no painel $\mathrm{B}$ aponta o muco corado com PAS. Nos outros painéis (A e C) não se evidencia presença significativa de muco. As três fotografias de microscopia ótica foram coradas com HE e PAS. 
Nos grupos submetidos à ovariectomia e posteriormente tratados com estradiol (grupo $\mathrm{OVx}$ Alérgico+E) ou com progesterona (grupo OVx Alérgico+P) não detectou-se quantidade significativa de muco nas vias aéreas estudadas (distais), como pode ser observado na figura 11. Os animais desses grupos demonstraram, no entanto, outros sinais de remodelamento das vias aéreas, destacando-se entre eles o espessamento do epitélio de revestimento interno (epitélio luminal) e a hipertrofia da musculatura lisa peri-bronquiolar (figura 12 - painel "A" e "B").

Figura 11- Percentual de muco nas vias aéreas dos grupos experimentais com 9 desafios alérgicos tratados com HSFs

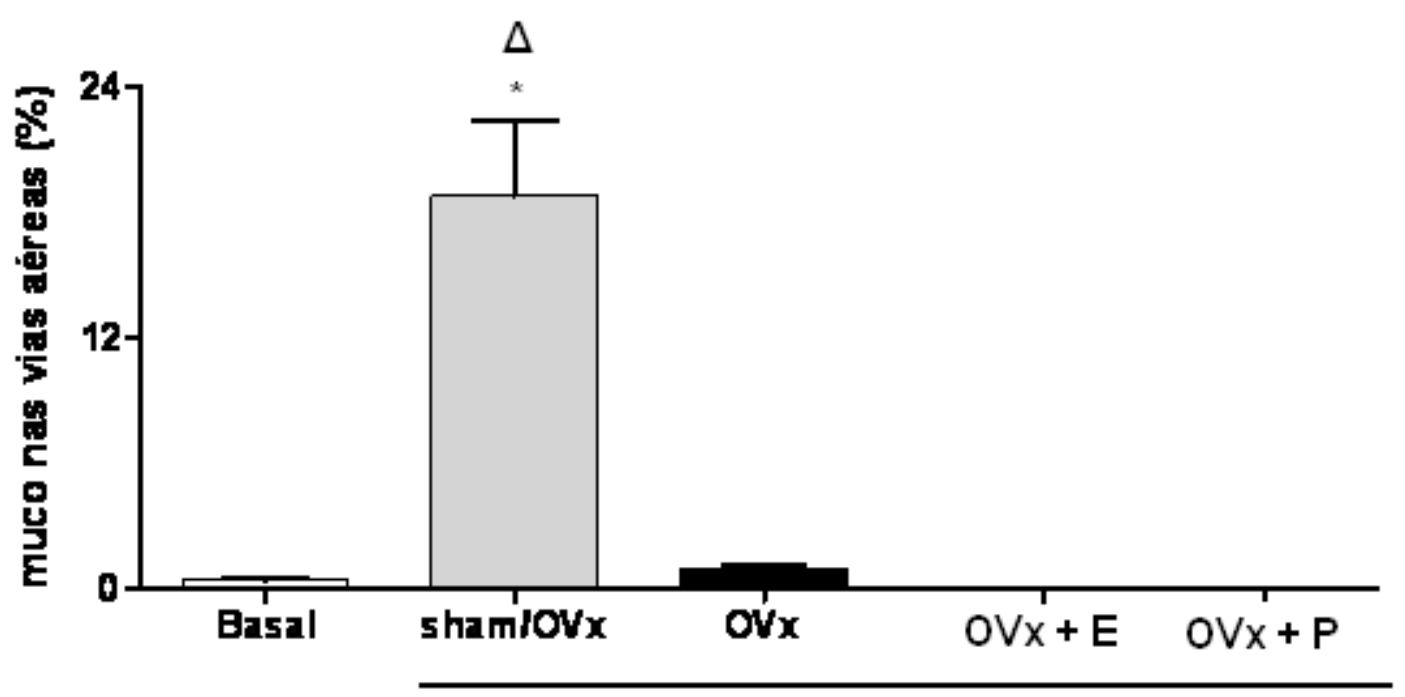

Alérgicos

Efeito da ovariectomia sobre o percentual de muco nas vias aéreas em modelo murino de inflamação alérgica pulmonar crônica com 9 desafios alérgicos e tratados com 17ß-estradiol (OVx Alérgico+E) ou progesterona $(\mathrm{OVx}$ Alérgico+P). Os resultados são expressos em porcentagem em relação à área total da via aérea analisada. Os dados representam a média \pm epm do grupo de animais. $*=p<0.05$ em relação ao grupo basal. $\Delta=\mathrm{p}<0.05$ em relação ao grupo $\mathrm{OVx}$.

Na figura 12, o painel " $A$ " mostra uma fotomicrografia de bronquíolo de animal do grupo OVx-alérgico + E na qual não se observa presença de muco. O painel " $\mathrm{B}$ " mostra fotomicrografia de animal do grupo $\mathrm{OVx}$-alérgico $+\mathrm{P}$ na qual também não observamos presença de muco. Em ambas as fotomicrografias pode-se observar espessamento de epitélio 
de revestimento da via aérea com conseqüente diminuição de sua região luminal (evidencia de remodelamento).

\section{Figura 12 - Fotomicrografia das vias aéreas dos grupos OVx alérgico+E e OVx alérgico+P corados com P.A.S. para revelação de muco.}

\section{OVx alérgico+E}

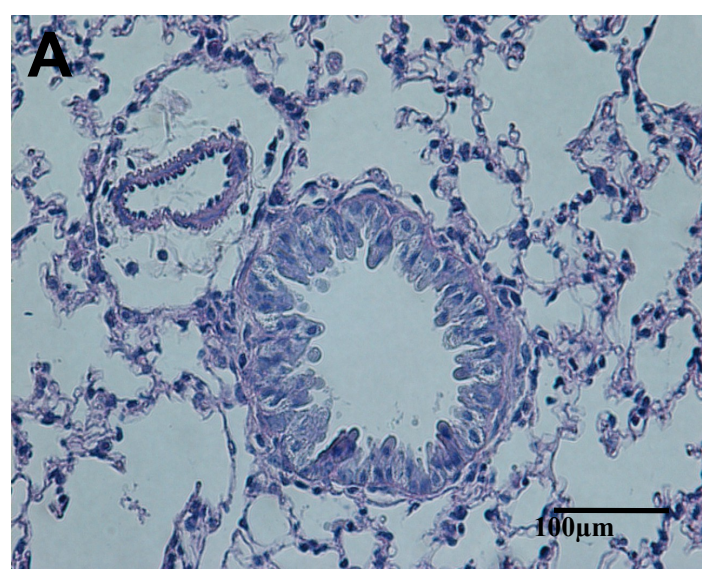

OVx alérgico+P:

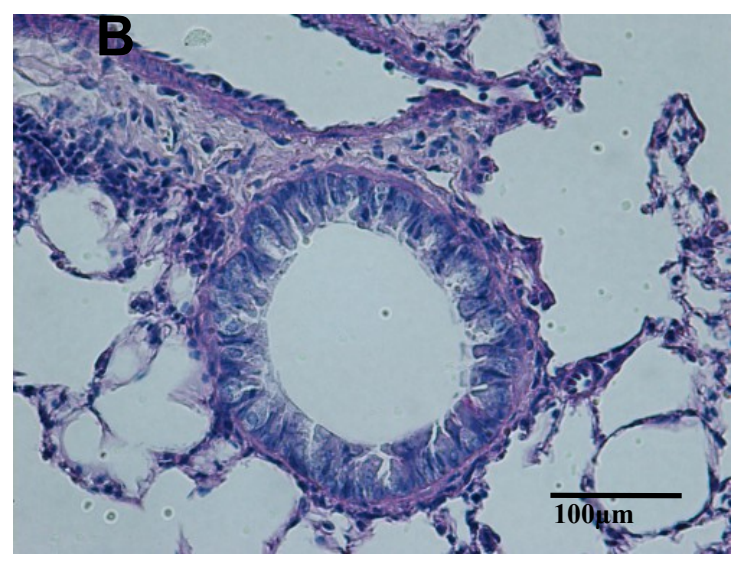

Fotomicrografia de bronquíolos de camundongos fêmeas em modelo de inflamação pulmonar alérgica crônica no aumento de $40 \mathrm{x}$. O painel A representa bronquíolo distal de animal do grupo ovariectomizado tratado com $17 \beta$-estradiol (OVx alérgico+E). Painel B mostra bronquíolo distal de animal do grupo ovariectomizado tratado com progesterona $(\mathrm{OVx}$ alérgico $+\mathrm{P})$. As duas fotografias de microscopia ótica foram coradas com HE e PAS para revelação de muco. .

\subsection{Efeitos da ovariectomia sobre a quantificação de colágeno nas vias aéreas}

Nos animais alérgicos (grupo sham-OVx alérgico e grupo OVx alérgico) o percentual de colágeno nas vias aéreas aumentou significativamente em relação à do grupo basal. No grupo OVx alérgico o percentual de colágeno nas vias aéreas foi significativamente menor do que no grupo sham-OVx alérgico (figura 13). 
Figura 13- Percentual de colágeno nas vias aéreas de animais submetidos a 9 desafios alérgicos

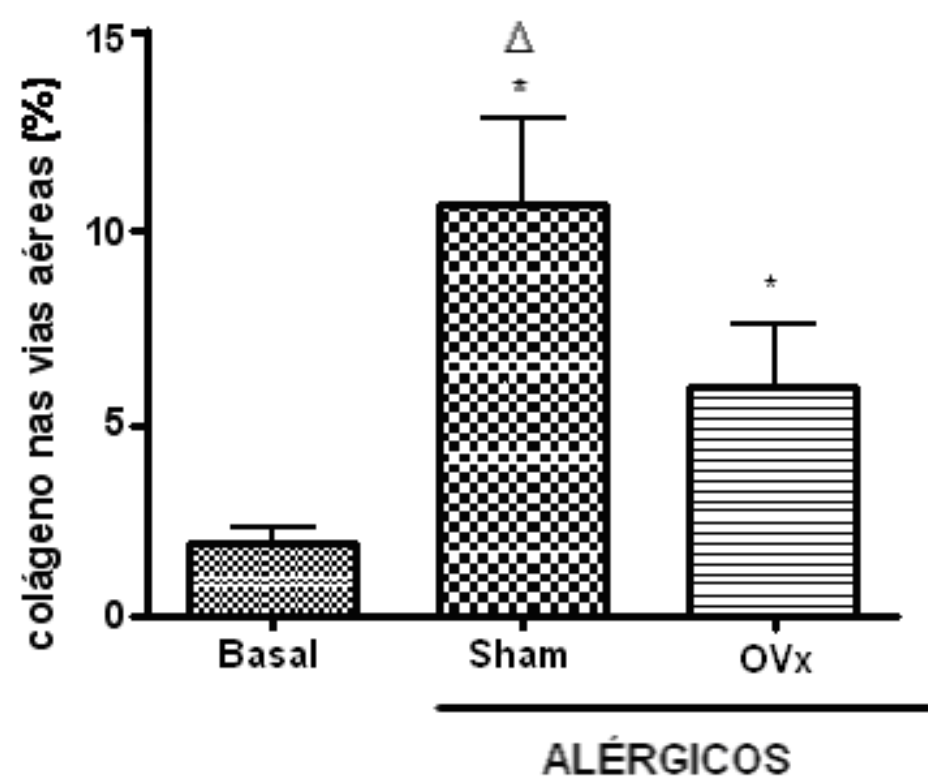

Efeito da ovariectomia sobre o percentual de fibras colágenas em modelo murino de inflamação pulmonar alérgica crônica com nove desafios alérgicos. O percentual de colágeno foi determinado pela razão da área de positividade para colágeno e a área de superfície total da via aérea correspondente. Os resultados são expressos em porcentagem em relação à área total da via aérea analisada. Os dados representam a média \pm epm do grupo de animais. $*=p<0.05$ em relação ao grupo basal. $\Delta=\mathrm{p}<0.05$ em relação ao grupo OVx-alérgico.

A figura 14 mostra fotomicrografia de via aérea distal de animal do grupo basal. Nesta figura podemos observar que normalmente nestes animais, grande parte das fibras colágenas situa-se no espaço perivascular (seta). 
Figura 14- Fotomicrografia de bronquíolo distal de animal do grupo basal corado com picrussirius red para revelação de colageno

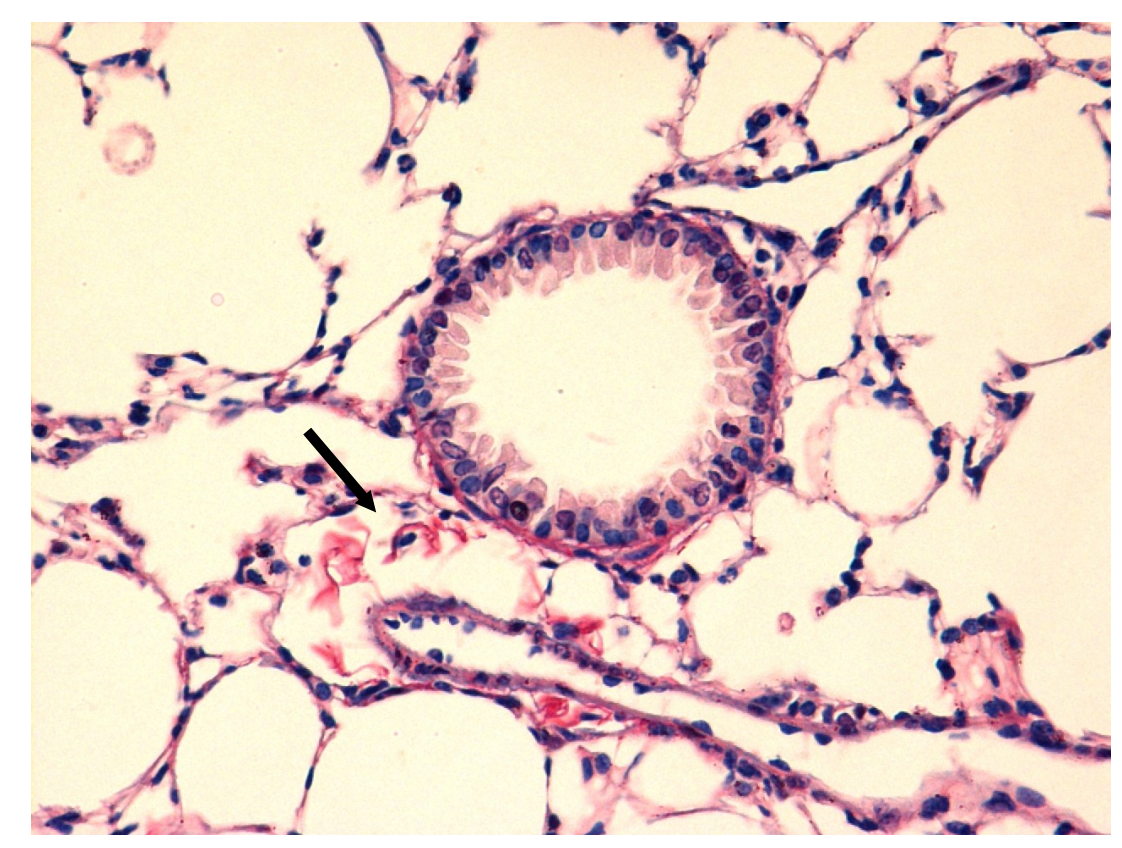

Fotomicrografia de bronquíolo de camundongo fêmea em modelo de inflamação pulmonar alérgica crônica no aumento de 40x. A figura representa bronquíolo distal de animal do grupo basal corado com $\mathrm{HE}+$ picrussirius red para marcação de fibras de colágeno. A maior concentração de fibras colágenas encontra-se na região entre a via aérea e seu vaso adjacente (seta).

Nos animais ovariectomizados, submetidos a 9 desafios alérgicos que receberam tratamento com estradiol (grupo OVx-alérgico $+\mathrm{E}$ ), o percentual de colágeno nas vias aéreas distais foi significativamente menor do que o percentual de colágeno quantificado no grupo sham-OVx alérgico. O grupo OVx-alérgico $+\mathrm{E}$ também teve percentual de colágeno menor do que o do grupo OVx-alérgico. No grupo de animais ovariectomizados alérgicos submetidos a 9 desafios que receberam tratamento com progesterona $(\mathrm{OVx}$-alérgico $+\mathrm{P})$, o percentual de fibras colágenas nas vias aéreas aumentou em relação a todos os outros grupos de animais, alcançando quase o dobro da média do percentual do grupo sham OVx-alérgico (figura 15). 
Figura 15- Percentual de colágeno nas vias aéreas de animais submetidos a 9 desafios alérgicos e tratados com HSFs

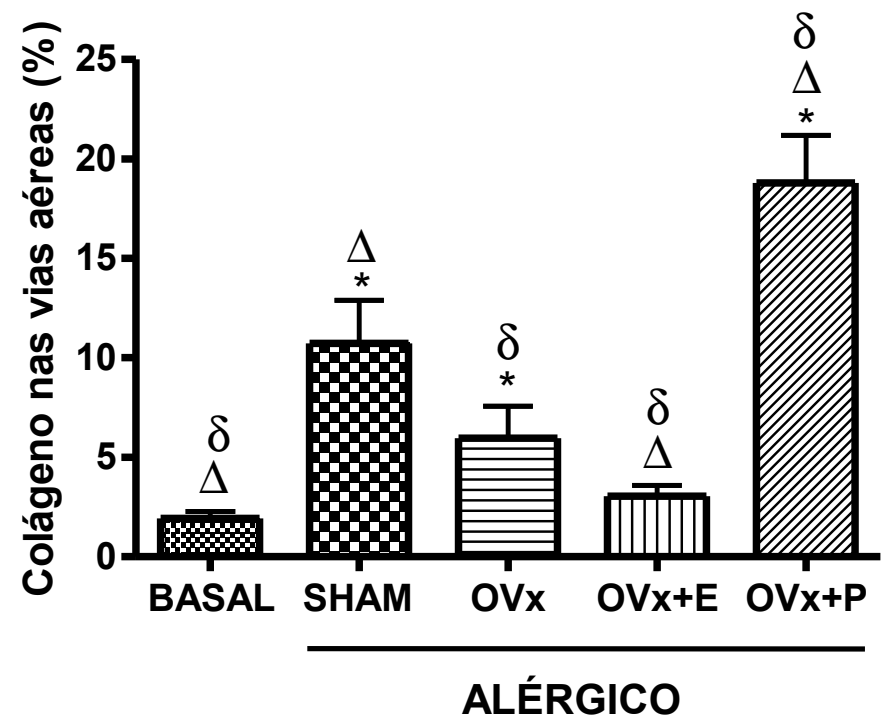

Efeito da ovariectomia e da reposição de HSFs sobre o percentual de colágeno presente nas vias aéreas distais em modelo murino de inflamação alérgica pulmonar crônica com 9 desafios alérgicos. A quantidade de colágeno foi determinada pela razão da área de positividade para colágeno e a área de superfície total da via aérea correspondente. Os resultados são expressos em porcentagem em relação à área total da via aérea analisada. Os dados representam a media \pm epm do grupo de animais. $*=\mathrm{p}<0.05$ em relação ao grupo basal. $\Delta=\mathrm{p}<0.05 \mathrm{em}$ relação ao grupo $\mathrm{OVx}$-alérgico $. \delta=\mathrm{p}<0.05$ em relação ao grupo Sham $\mathrm{OVx}$-alérgico.

$\mathrm{Na}$ figura 16 podemos observar quatro fotomicrografias representativas dos diferentes grupos experimentais. O painel "A" é uma fotomicrografia de animal do grupo sham OVxalérgico na qual se pode observar grande quantidade de colágeno ao redor da via aérea (seta) com coloração vermelho-fuccia dada pelo corante picrussirius red. No painel "B" temos uma fotomicrografia de animal do grupo OVx-alérgico, com o colágeno corado (seta) em quantidade notadamente menor do que no painel "A". No painel " $D$ " observa-se fotomicrografia de animal do grupo $\mathrm{OVx}$ alérgico $+\mathrm{P}$ com a seta mostrando o colágeno corado ao redor da via aérea em quantidade muito superior a de qualquer outra fotomicrografia desta figura. 
Figura 16 - Fotomicrografias das vias aéreas distais dos animais alérgicos coradas com picrussirius red para revelação colágeno

Sham OVx alérgico

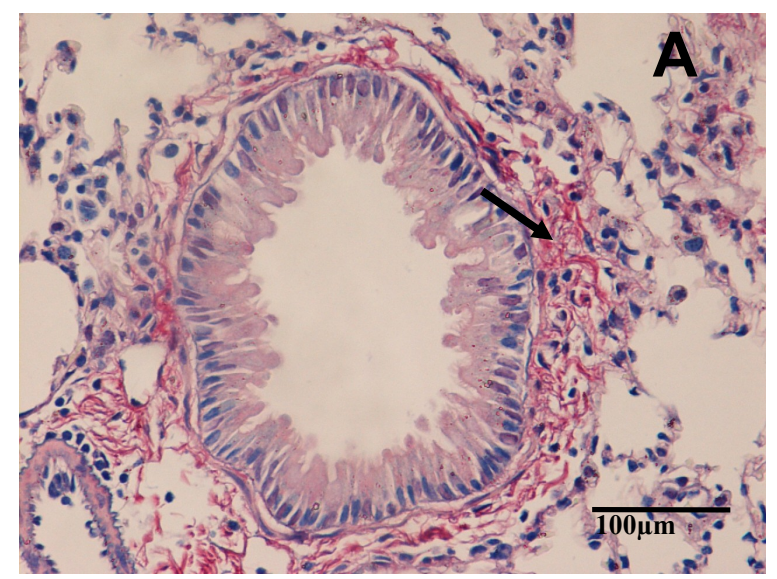

OVx alérgico+E

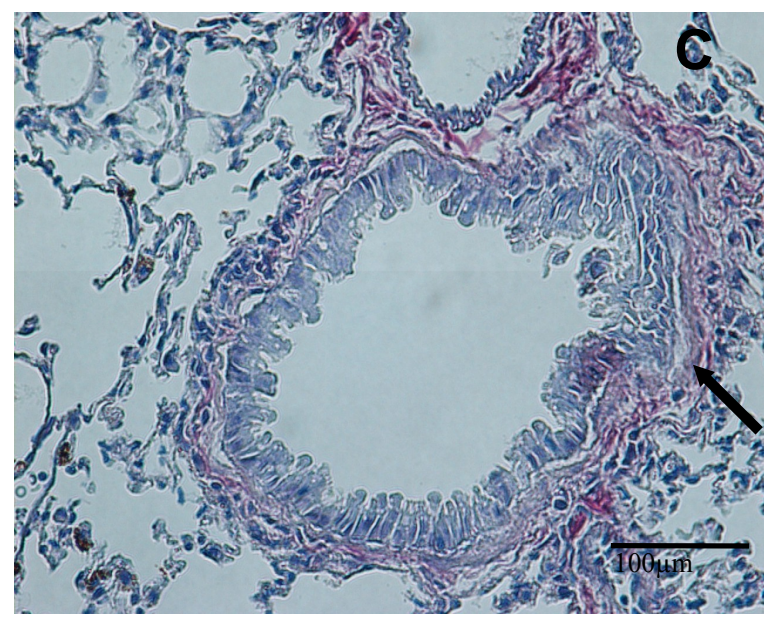

OVx alérgico

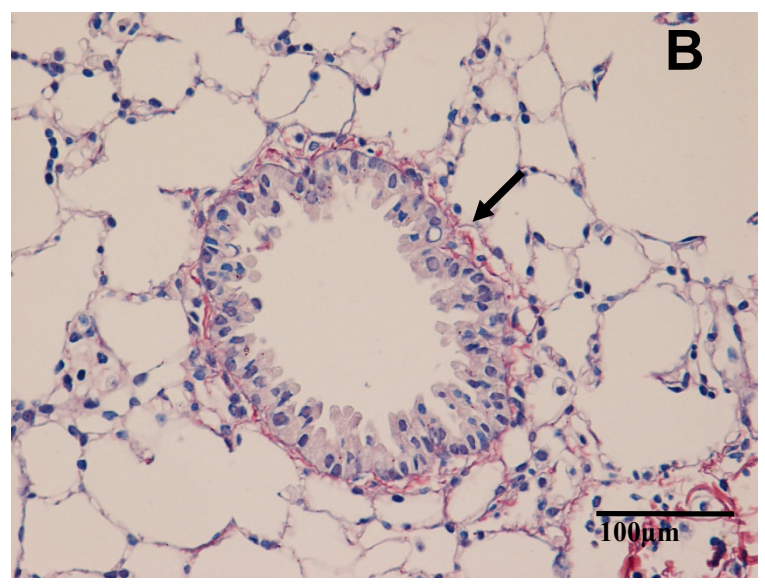

$\mathrm{O} / \mathrm{Vx}$ alérgico $+\mathrm{P}$

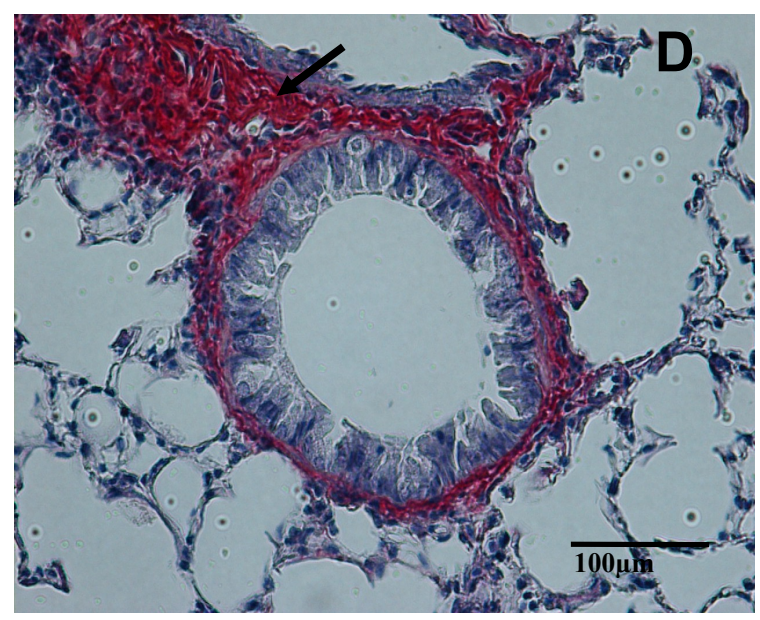

Fotomicrografia de bronquíolos de camundongos fêmeas em modelo de inflamação pulmonar alérgica crônica no aumento de 40x. O painel A representa bronquíolo distal de animal do grupo sham OVx alérgico corado com $\mathrm{HE}+$ picrussirius red para marcação de fibras de colágeno (seta). O painél B mostra bronquíolo distal de animal do grupo $\mathrm{OVx}$ alérgico. As fibras colágenas estão apontadas com a seta. O painel $\mathrm{C}$ corresponde a animal do grupo ovariectomizado com reposição de $17 \beta$-estradiol e o painel D apresenta bronquíolo distal de animal do grupo ovariectomizado com reposição de progesterona. Notar no painel C e D as fibras colágenas apontadas pela seta. Todos a fotomicrografias foram coradas por $\mathrm{HE}+$ picrussirius red. 


\subsection{Efeito da ovariectomia sobre a quantificação de músculo liso das vias aéreas}

Em animais submetidos a 9 desafios alérgicos, observamos que o grupo alérgico ovariectomizado (OVx-alérgico) demonstrou diminuição na quantificação da área ocupada por fibras musculares lisas nas vias aéreas em relação ao grupo falso-operado (sham OVx alérgico). O grupo $\mathrm{OVx}$ alérgico apresentou percentuais de fibras musculares lisas semelhantes ao grupo não manipulado (basal). Os animais ovariectomizados que receberam tratamento com estrógeno durante a sensibilização e os desafios alérgicos apresentaram percentuais de fibras musculares lisas semelhantes às do grupo alérgico falso-operado. Não houve aumento na quantificação de massa muscular lisa nos animais tratados com progesterona (OVx alérgico $+\mathrm{P})$. A figura 17 abaixo ilustra o efeito observado.

Figura 17 - Percentual de músculo liso nas vias aéreas dos grupos de animais submetidos a 9 desafios alérgicos

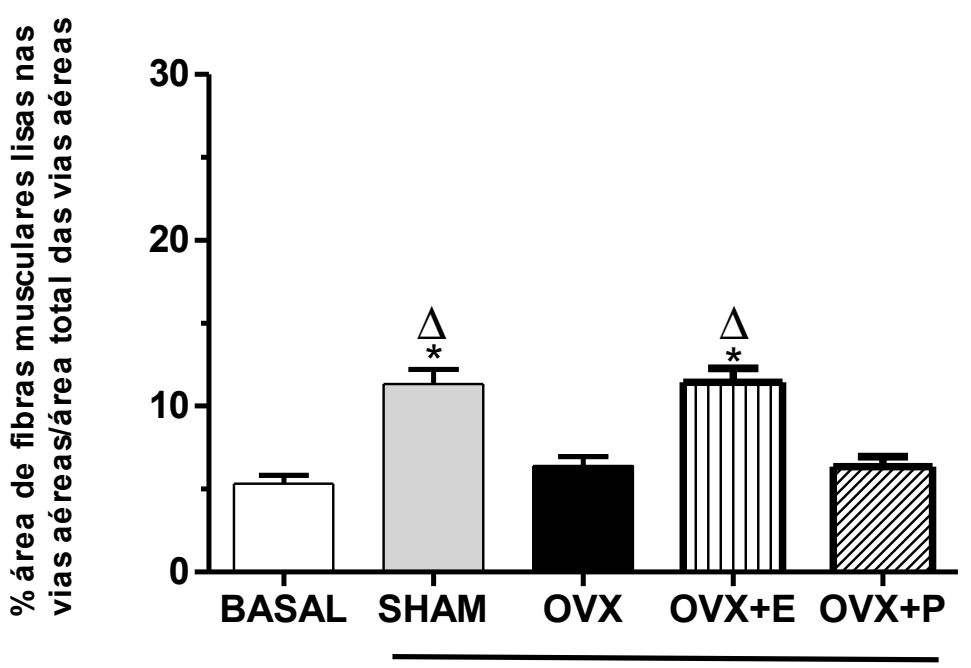

ALÉRGICO

Efeito da ovariectomia no percentual de área de musculatura lisa peri-bronquiolar em relação à área total das vias aéreas em modelo murino de inflamação alérgica pulmonar crônica com 9 desafios alérgicos. A quantificação das fibras musculares lisas das vias aéreas foi determinada pela razão da área de positividade para o fibras musculares lisas e a área de superfície total da via aérea correspondente. Os resultados são expressos em porcentagem em relação à área total da via aérea analisada. Os dados representam a media \pm epm do grupo de animais. $*=p<0.05$ em relação ao grupo basal. $\Delta=\mathrm{p}<0.05$ em relação ao grupo OVx-alérgico. 


\subsection{Efeito da ovariectomia e dos tratamentos com HSFs na quantificação de epitélio das vias aéreas.}

Tendo em vista a observação de que as vias aéreas de pequeno calibre de animais alérgicos apresentam-se com diminuição luminal em relação a animais não-tratados, resolvemos verificar se esta diminuição luminal devia-se a um aumento do tamanho ou do aumento da estratificação do epitélio respiratório de revestimento das vias aéreas.

Observamos que existe considerável hiperplasia das células epiteliais de revestimento das vias aéreas de animais alérgicos em relação a animais não-alérgicos refletindo num aumento da quantificação de área de epitélio, porém não foram observadas diferenças significativas entre os grupos sham OVx-alérgico e grupo OVx-Alérgico. A figura 18 abaixo ilustra os resultados para quantificação de epitélio entre os grupos.

Figura 18 - Percentual da área ocupada pelo epitélio nas vias aéreas dos grupos submetidos a 9 desafios alérgicos

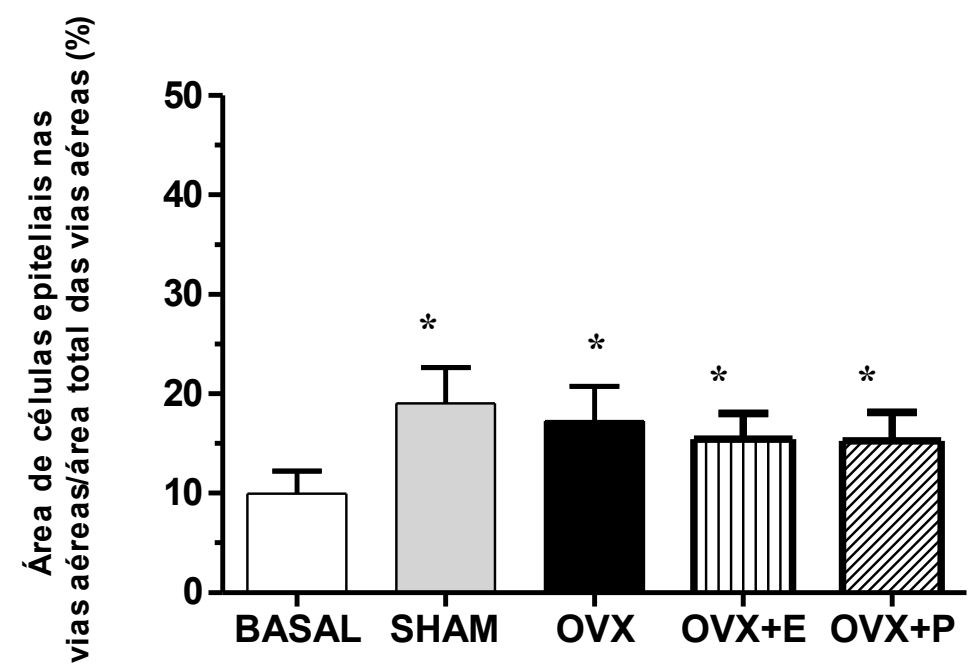

Efeito da ovariectomia no percentual de área de epitélio respiratório de revestimento das vias aéreas em relação à área total das vias aéreas no modelo murino de inflamação alérgica pulmonar crônica com 9 desafios alérgicos. A quantificação do epitélio respiratório foi determinada pela razão da área marcada de epitélio e a área de superfície total da via aérea correspondente. Os resultados são expressos em porcentagem em relação à área total da via aérea analisada. Os dados representam a media \pm epm do grupo de animais. $*=\mathrm{p}<0.05$ em relação ao grupo basal. 


\subsection{Efeito da ovariectomia sobre a morfologia vias aéreas distais}

Realizamos a análise morfométrica de bronquíolos distais (vide seção 4- materiais e métodos, item 4.2.5) calculando o quociente entre a área total da via aérea medida a partir de sua membrana basal e a área da luz da via aérea quantificada a partir da borda luminal do epitélio respiratório. Este quociente representa a relação entre estas duas medidas. Na via aérea normal,estas áreas tem uma relação e o quociente se aproxima de 2. Quando ocorre o estreitamento da luz da via aérea, esta relação se perde e o quociente aumenta. Quanto menor o quociente entre as áreas, maior é o calibre da via aérea. Esta medida permite comparar os diferentes animais sem a interferência das diferenças da constituição individual de cada indivíduo. A avaliação da diminuição luminal por histologia demonstram o estreitamento das vias aéreas dos sham-OVx alérgicos em relação aos animais não manipulados (grupo basal) evidenciando remodelamento de bronquíolos distais. Verifica-se que a ovariectomia (grupo OVx-Alérgico) previne em algum grau a diminuição luminal das pequenas vias aéreas. A figura 19 abaixo ilustra este resultado.

Figura 19 - Avaliação da razão parede-luz das vias aéreas

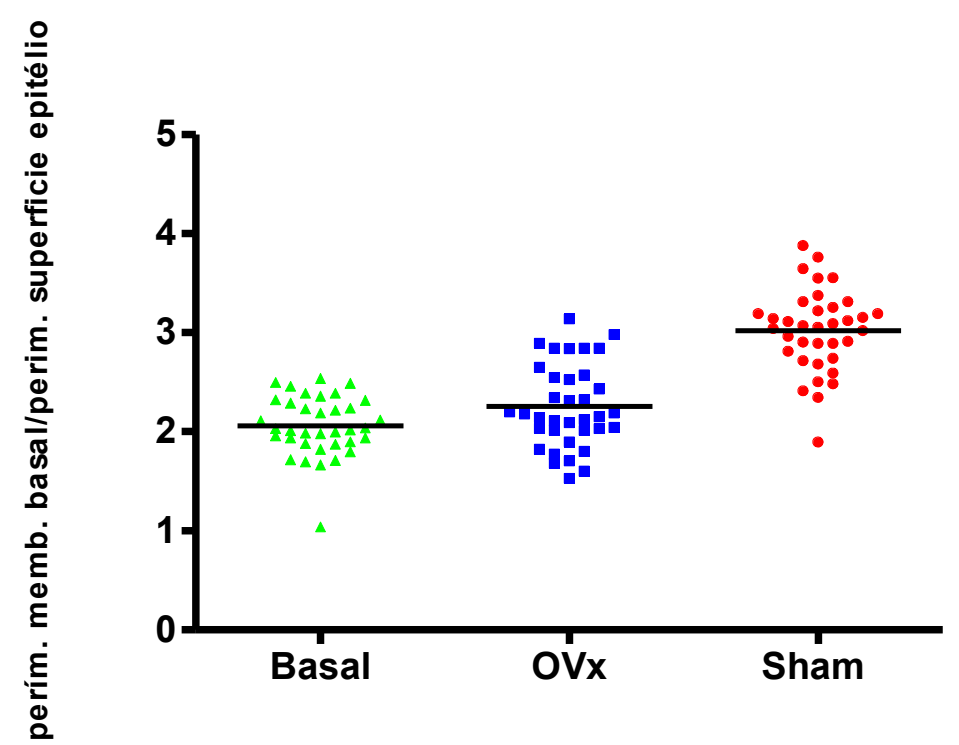

Morfometria de bronquíolos distais cinco dias após o último desafio alérgico dos animais. Cada ponto representa o quociente entre a área total da via aérea e a área da luz da respectiva via aérea dos animais de cada grupo. As cores diferenciam os indivíduos de cada grupo: basal (verde), OVx alérgico (azul) e sham OVx alérgico (vermelho). A linha horizontal representa a mediana dos grupos. Quanto maior o quociente, menor o calibre das vias aéreas. Animais submetidos ao protocolo de 9 desafios alérgicos. 


\subsection{Efeito da ovariectomia na reatividade ex vivo de traqueia isolada}

Os resultados da curva concentração-efeito dos anéis de traquéia à metacolina estão representados nos gráficos abaixo. Observa-se que o grupo OVx-alérgico apresenta reatividade dos anéis de traqueia similares aos do grupo basal, já o grupo alérgico, falsooperado (Sham-OVx alérgico) possui uma reatividade cerca de 4 vezes maior quando submetido às mesmas concentrações de metacolina.

Figura 20 - Reatividade dos anéis de traquéia ex vivo frente à estímulo colinérgico do grupo ovariectomizado em relação ao grupo não manipulado e o grupo falso-operado

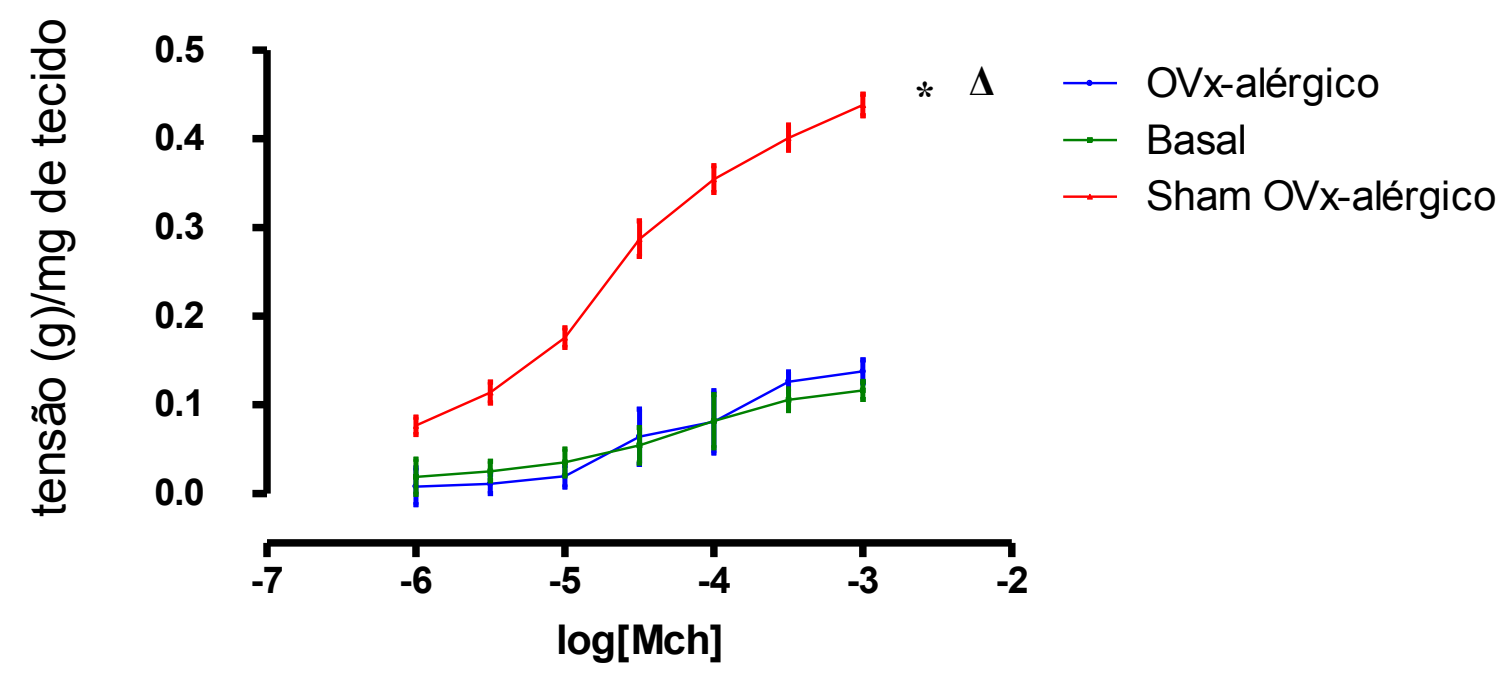

Efeito da ovariectomia sobre a reatividade de anéis traqueais ex vivo à metacolina em animais submetidos ao protocolo de 9 desafios alérgicos. $\mathrm{N}$ de 8 por grupo. $*=\mathrm{p}<0.05$ em relação ao grupo basal, $\Delta=\mathrm{p}<0.05 \mathrm{em}$ relação ao grupo OVx-alérgico.

Os testes de reatividade ex vivo nos grupos que foram ovariectomizados e tratados com progesterona $(\mathrm{OVx}$-alérgico $+\mathrm{P})$ não foram significativamente diferentes dos observados nos grupos basal e OVx-alérgico. O grupo tratado com 17ß-estradiol (OVx-alérgico+E) apresentou reatividade de anéis de traquéia mais elevada que as dos grupos basal, OVxalérgico e $\mathrm{OVx}$-alérgico+P, porém não alcançaram os níveis de reatividade demonstrados pelo grupo sham OVx-alérgico. Abaixo, podemos observar num só gráfico, as diferenças dos níveis tensionais alcançados por cada grupo. Os animais do grupo sham $\mathrm{OVX}$-alérgicos 
mostraram o maior índice de reatividade de tecido traqueal em curva dose-resposta de estimulação com metacolina.

Figura 21 - Reatividade dos anéis de traquéia ex vivo frente a estímulo colinérgico de todos os grupos experimentais

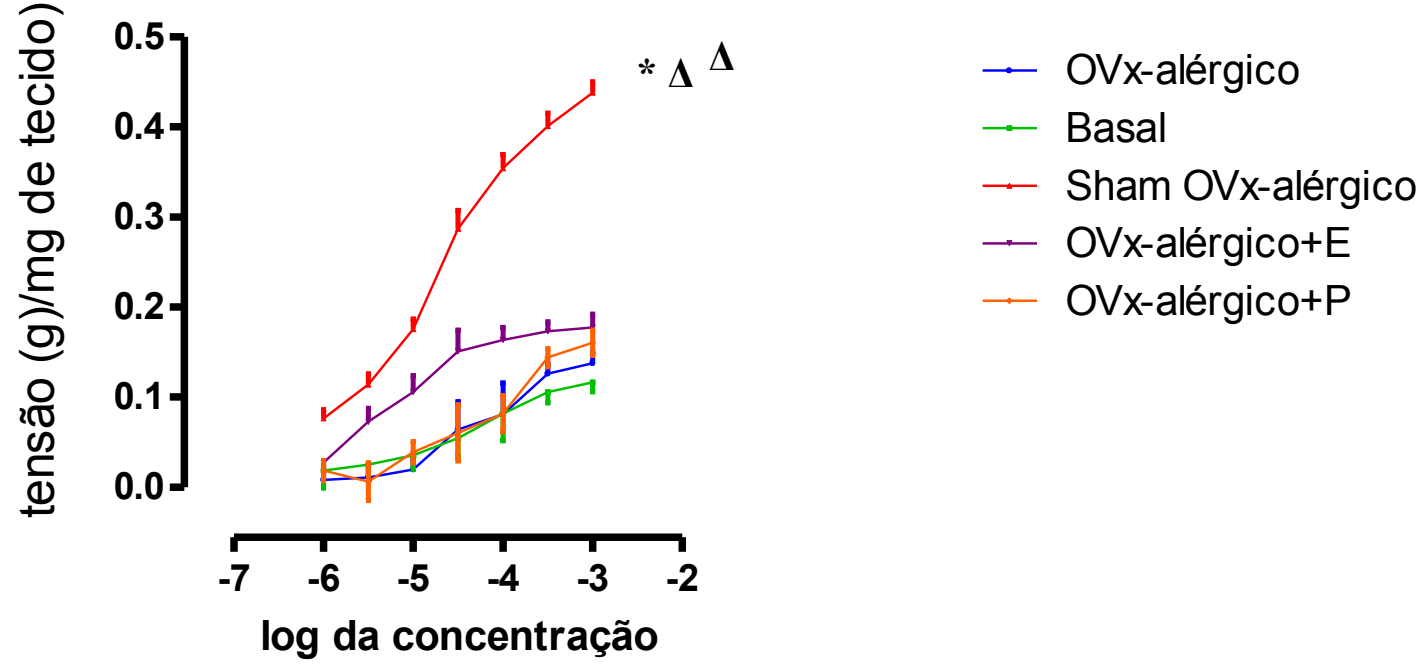

Efeito da ovariectomia e dos tratamentos de animais ovariectomizados com estradiol $(\mathrm{OVx}+\mathrm{E})$ e com progesterona $(\mathrm{OVx}+\mathrm{P})$ sobre a reatividade de anéis traqueais ex vivo à metacolina. Animais submetidos ao protocolo de 9 desafios alérgicos. $\mathrm{N}$ de 8 por grupo. $*=\mathrm{p}<0.05$ em relação ao grupo basal, $\Delta=\mathrm{p}<0.05 \mathrm{em}$ relação ao grupo OVx-alérgico.

5.9 Efeito da ovariectomia e dos tratamentos com HSFs na quantificação de MMPs 2 e 9 no parênquima pulmonar

Os gráficos a seguir ilustram as diferenças na quantificação de metaloproteinases de parênquima pulmonar entre os grupos. e as células obtidas foram coradas em lâminas. 
Figura 22- Quantificação de Metaloproteinase 2 no parênquima pulmonar dos grupos de experimentação

MMP-2

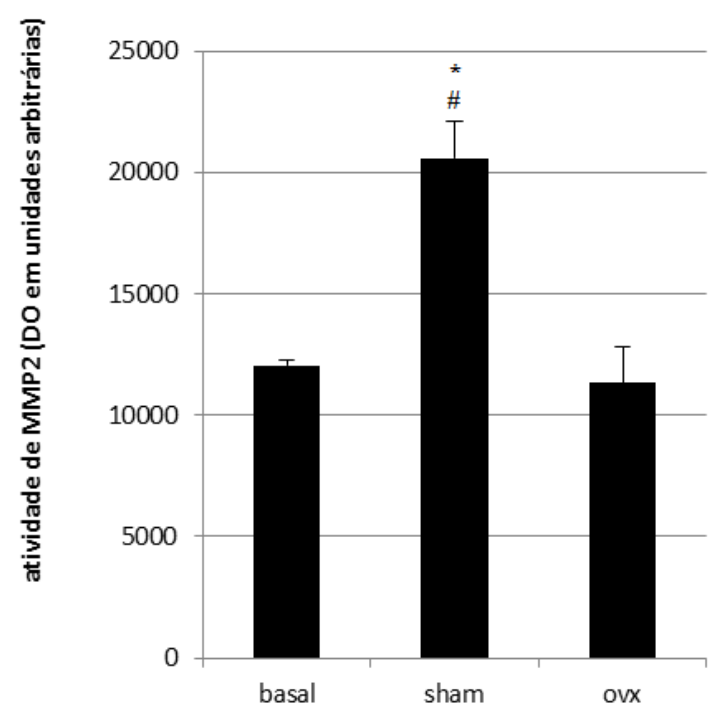

MMP-2

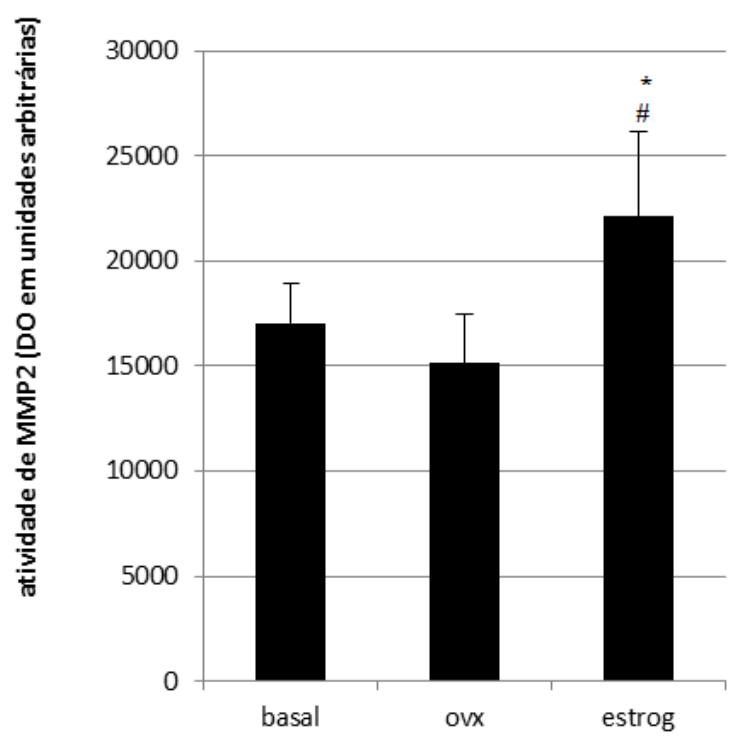

MMP-2

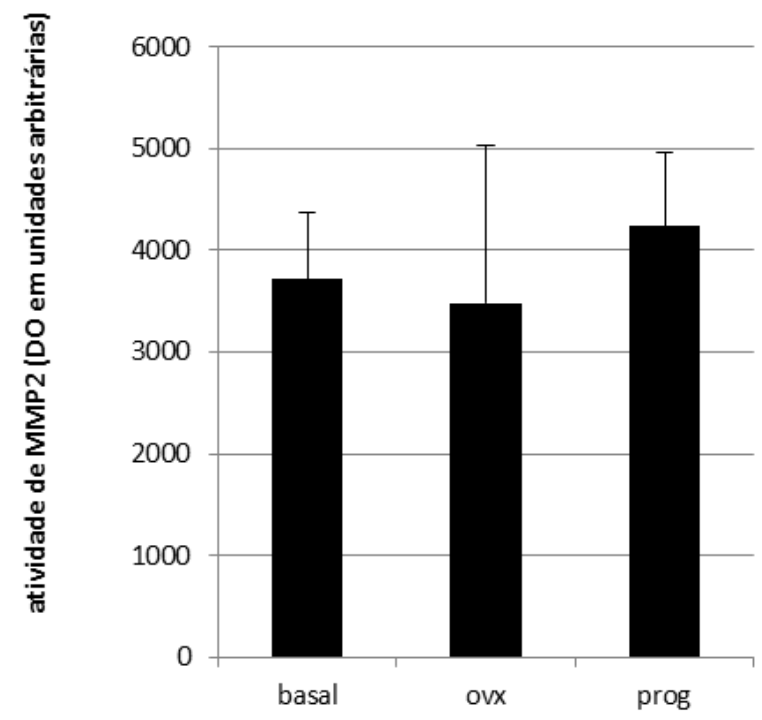

Quantificação de MMP-2. Devido às diferentes extrações de proteínas (MMPs) em cada gel de eletroforese, os grupos só podem ser comparados com os outros presentes no mesmo zimograma. Animais submetidos ao protocolo de 9 desafios alérgicos. Grupos de 4 a 7 animais* $=p<0.05$ em relação ao grupo basal. $\#=p<0.05$ em relação ao grupo OVx/Alérgico. 
Figura 23 - Quantificação de Metaloproteinase 9 no parênquima pulmonar dos grupos de experimentação

MMP-9

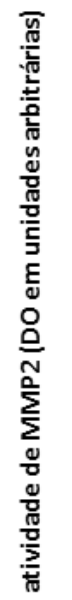
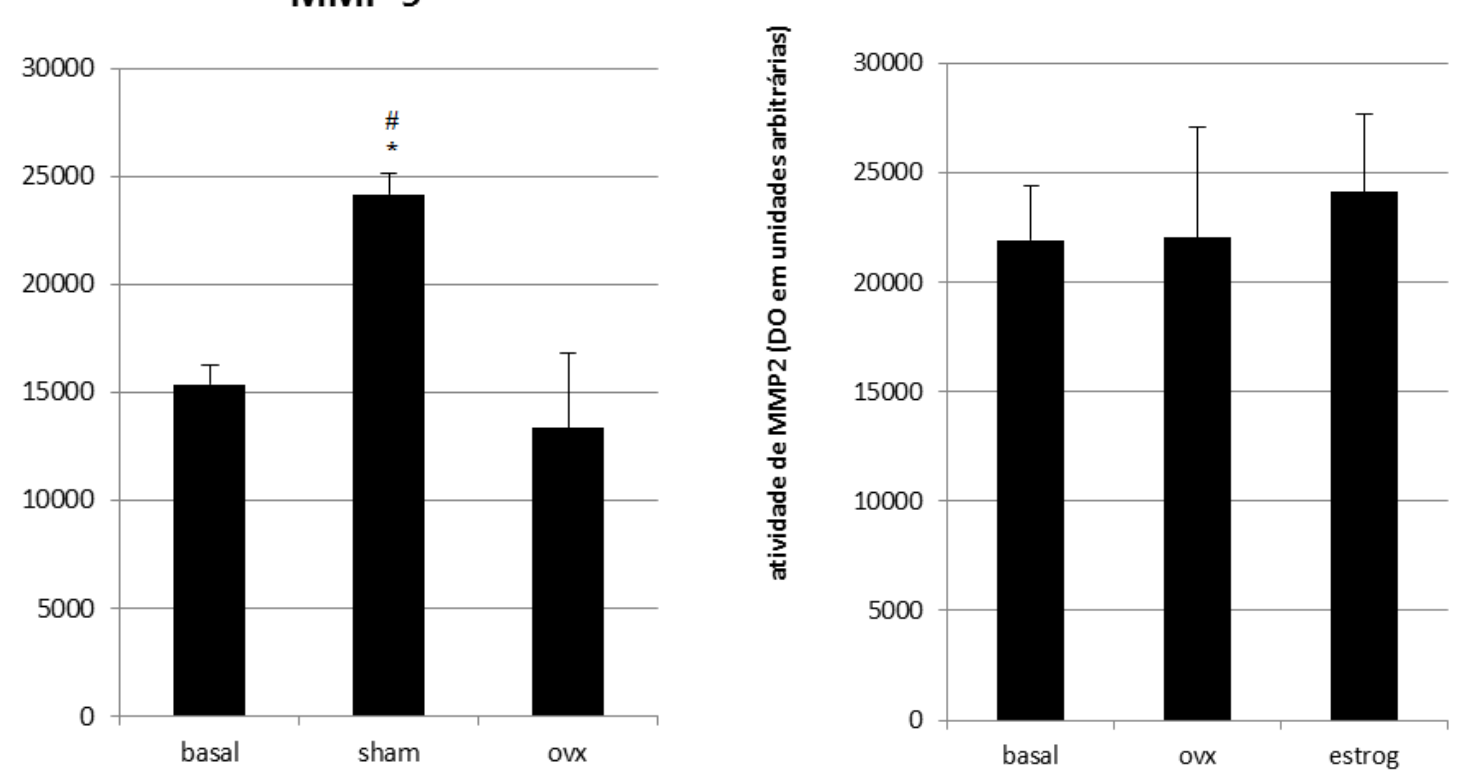

MMP-9

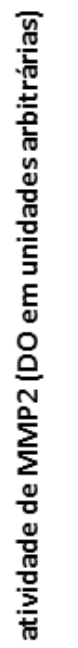

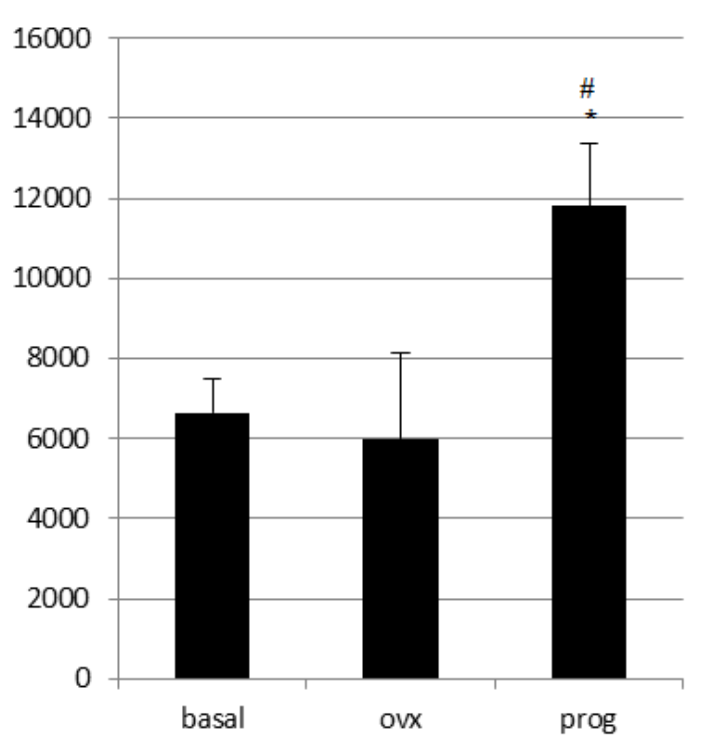

Quantificação de MMP-9. Devido às diferentes extrações de proteínas (MMPs) em cada gel de eletroforese, os grupos só podem ser comparados com os outros presentes no mesmo zimograma. Animais submetidos ao protocolo de 9 desafios alérgicos. Grupos de 4 a 7 animais. $*=p<0.05$ em relação ao grupo basal. $\#=p<$ 0.05 em relação ao grupo OVx-alérgico. 
O grupo sham OVx-alérgico, apresentou quantificação de MMP-2 quase duas vezes mais elevada que o grupo basal e o grupo OVx-alérgico. O grupo OVx-alérgico + E também demonstrou maior quantificação de MMP-2 em relação ao grupo basal e OVx-alérgico. Não observou-se diferença significativa entre os grupos basal, OVx-alérgico e OVx-alérgico + P.foram

O grupo sham OVx-alérgico, apresentou quantificação de MMP-9 mais elevada que o grupo basal e o grupo OVx-alérgico. O grupo OVx-alérgico + $\mathrm{P}$ também demonstrou maior quantificação de MMP-9 em relação ao grupo basal e OVx-alérgico. Não observou-se diferença significativa entre os grupos basal, OVx-alérgico e OVx-alérgico+E.

\subsection{Avaliação da mecânica Pulmonar}

Primeiramente procedeu-se à validação do modelo de avaliação de mecânica ventilatória no estudo da inflamação pulmonar alérgica crônica. Mensurou-se as médias dos pontos máximos de resistência das vias aéreas em condições basais (sem broncoprovocação por estímulo colinérgico) e após instilação de MCh intra-traqueal por micronebulização.

Figura 24- Medida da resistência das vias aéreas

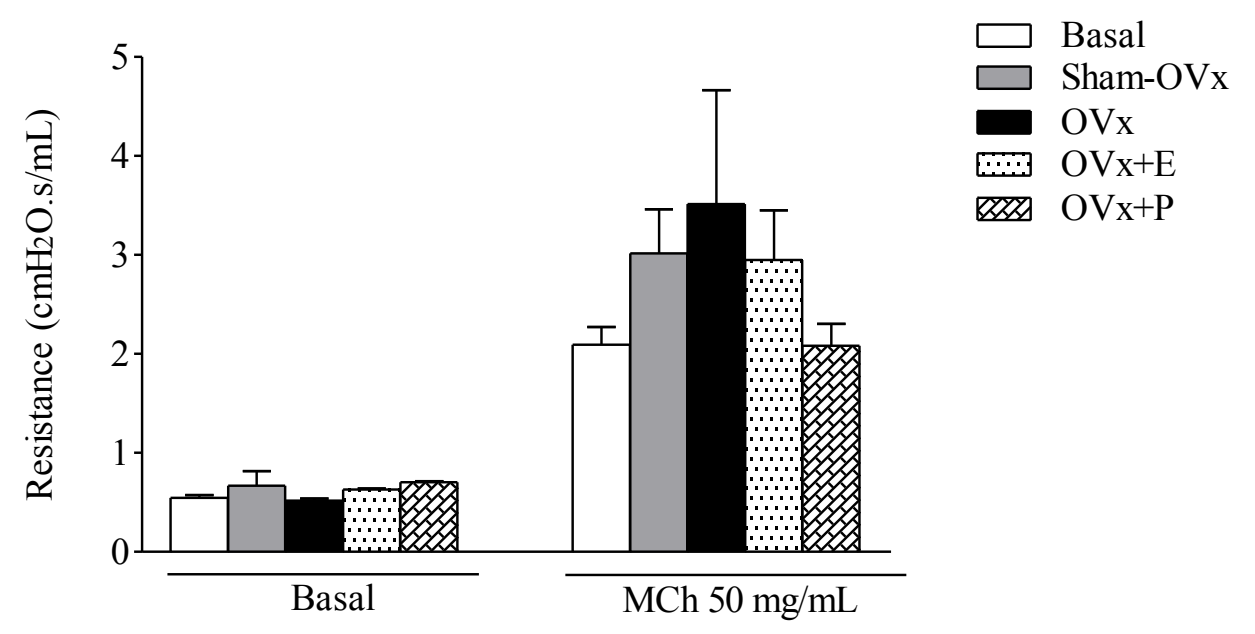

Médias dos pontos máximos de resistência pulmonar calculadas para modelo unicompartimental durante o estudo da inflamação pulmonar alérgica crônica. As colunas sob a barra "Basal" referem-se às médias das medições de resistência das vias aéreas nos animais antes da broncoprovocação com metacolina. As colunas sob a barra "MCh $50 \mathrm{mg} / \mathrm{mL}$ " referem-se às médias das medidas de resistência das vias aéreas nos animais após broncoprovocação com metacolina $50 \mathrm{mg} / \mathrm{mL}$ via inalatória (micronebulização intra-traqueal). 
Também procedeu-se à avaliação da média dos pontos máximos de elastância das vias aéreas em condições basais (sem broncoprovocação por estímulo colinérgico) e após instilação de MCh intra-traqueal por micronebulização.

Figura 25- Medida da elastância das vias aéreas

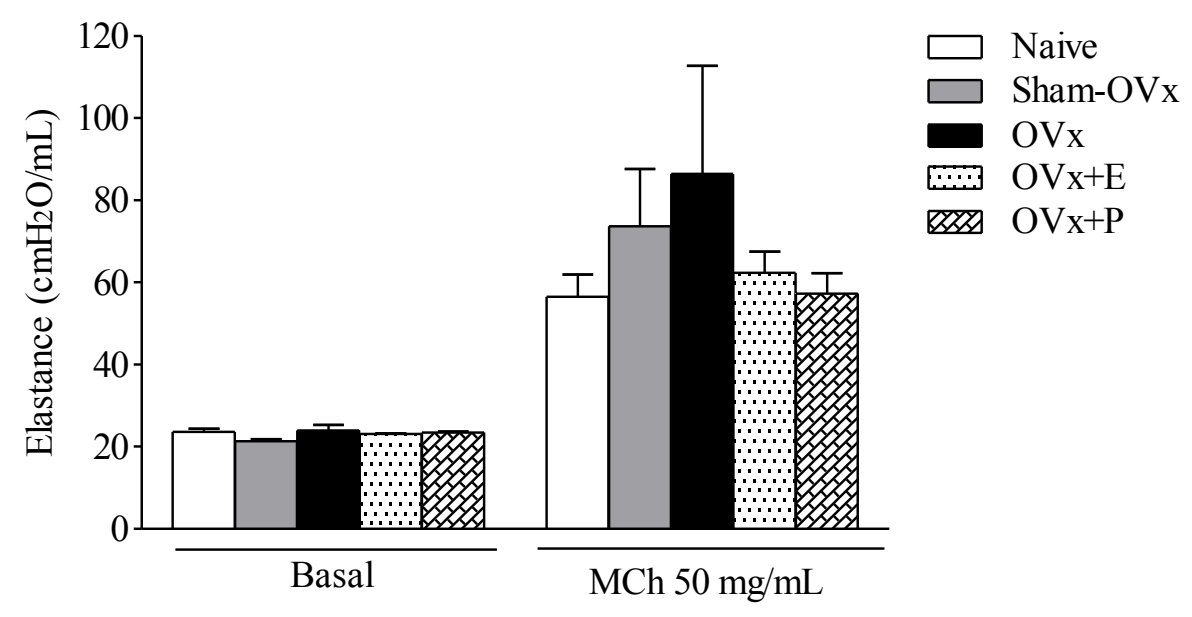

Médias dos pontos máximos de elastâncias pulmonares calculadas para modelo unicompartimental. As colunas sob a barra "Basal" referem-se às médias das medições de elastância das vias aéreas nos animais antes da broncoprovocação com metacolina. As colunas sob a barra "MCh $50 \mathrm{mg} / \mathrm{mL}$ " referemse às médias das medidas de elastância das vias aéreas nos animais após broncoprovocação com metacolina $50 \mathrm{mg} / \mathrm{mL}$ via inalatória (micronebulização intra-traqueal).

Seguiram-se medições de resistencia (R) e elastância (E) para cada grupo experimental. Cada ponto representa a média das resistências (em $\mathrm{cm}$ de água) ou da elastância (em cm de água) sequencial (medida a cada 30 segundos) de todos os animais do grupo em condições basais após estimulação com PBS e nas diferentes concentrações de $\mathrm{MCh}$. 
Figura 26- Medida da resistência das vias aéreas do grupo basal

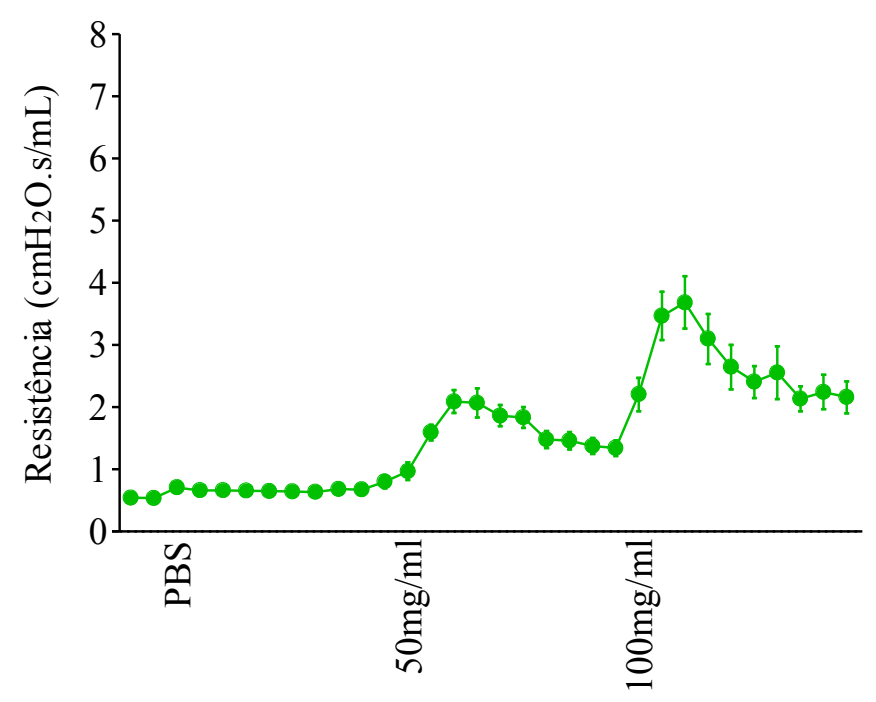

Médias das resistências sequenciais (a cada 30 segundos) de vias aéreas pulmonares após nebulização intratraqueal com PBS e com MCh nas concentrações de 50 e $100 \mathrm{mg} / \mathrm{mL}$.

Figura 27- Medida da elastância das vias aéreas do grupo basal

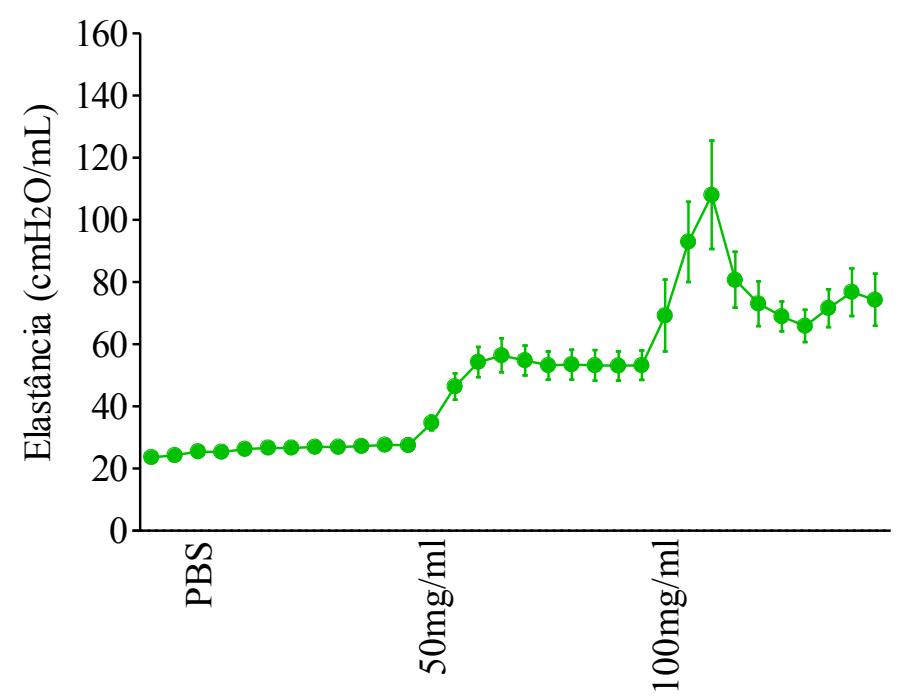

Médias das elastâncias sequenciais (a cada 30 segundos) pulmonares após nebulização intra-traqueal com PBS e com MCh nas concentrações de 50 e $100 \mathrm{mg} / \mathrm{mL}$. 
Figura 28- Medida da resistência das vias aéreas do grupo sham OVx alérgico

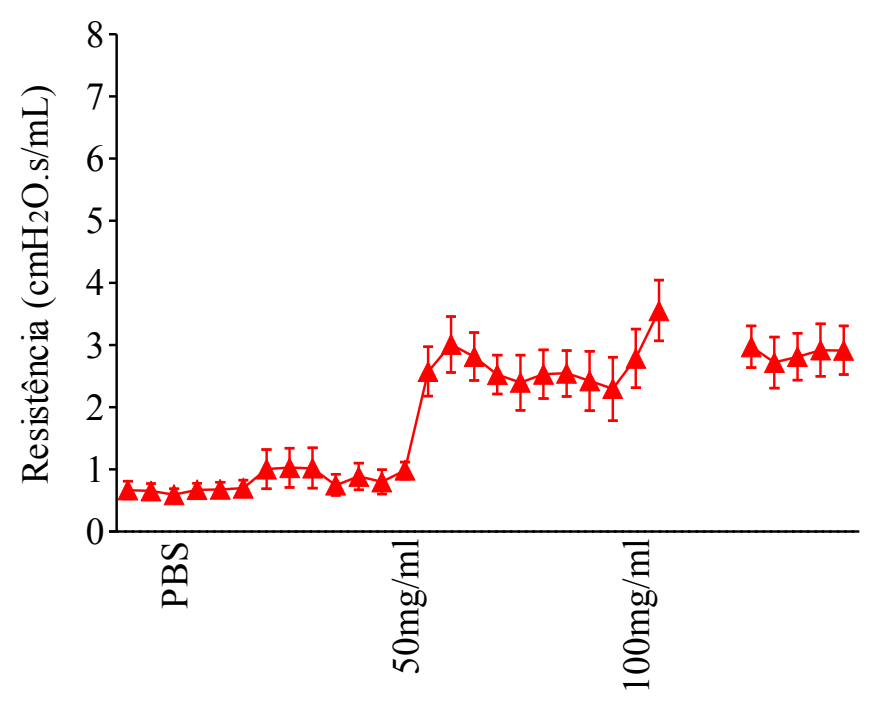

Médias das resistências sequenciais (a cada 30 segundos) pulmonares após nebulização intra-traqueal com PBS e com MCh nas concentrações de 50 e $100 \mathrm{mg} / \mathrm{mL}$.

Figura 29- Medida da elastância das vias aéreas do grupo sham OVx alérgico

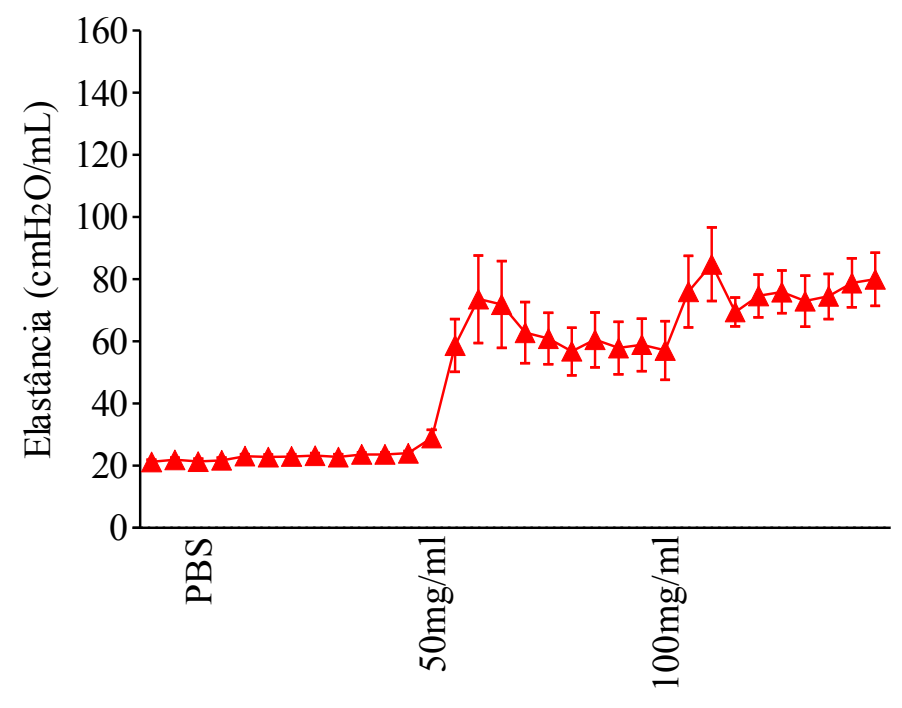

Médias das elastâncias sequenciais (a cada 30 segundos) pulmonares após nebulização intra-traqueal com PBS e com MCh nas concentrações de 50 e $100 \mathrm{mg} / \mathrm{mL}$. 
Figura 30- Medida da resistência das vias aéreas do grupo OVx alérgico

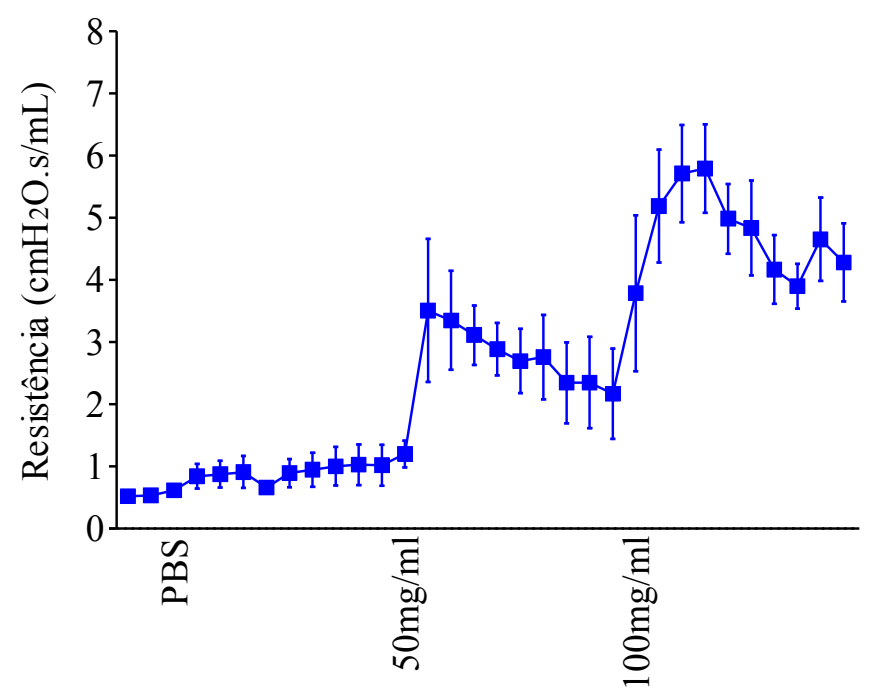

Médias das resistências sequenciais (a cada 30 segundos) pulmonares após nebulização intra-traqueal com PBS e com MCh nas concentrações de 50 e $100 \mathrm{mg} / \mathrm{mL}$.

Figura 31- Medida da elastância das vias aéreas do grupo OVx alérgico

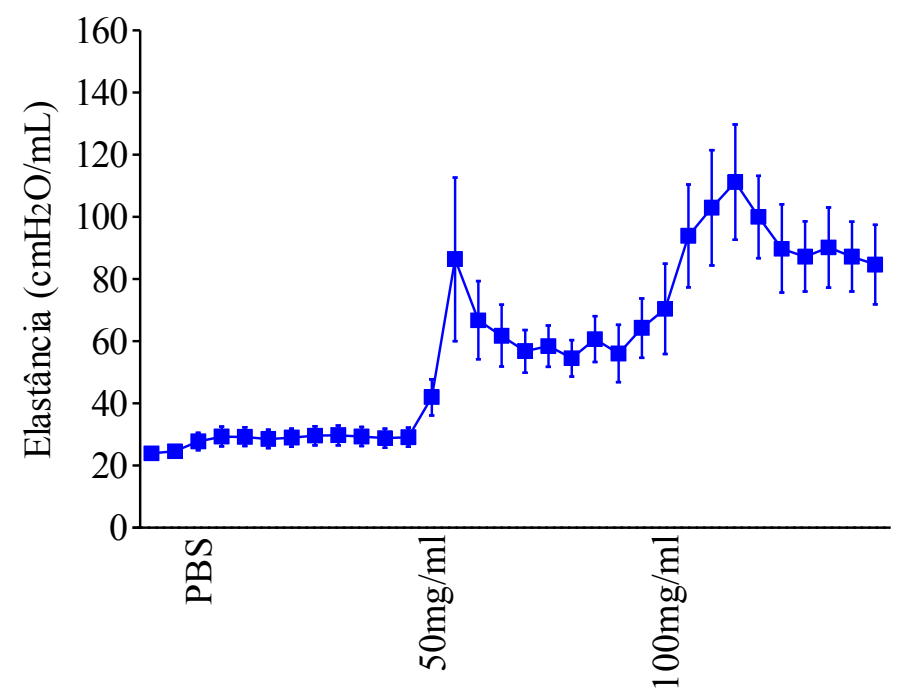

Médias das elastâncias sequenciais (a cada 30 segundos) pulmonares após nebulização intra-traqueal com PBS e com MCh nas concentrações de 50 e $100 \mathrm{mg} / \mathrm{mL}$. 
Figura 32- Medida da resistência das vias aéreas do grupo OVx alérgico+E

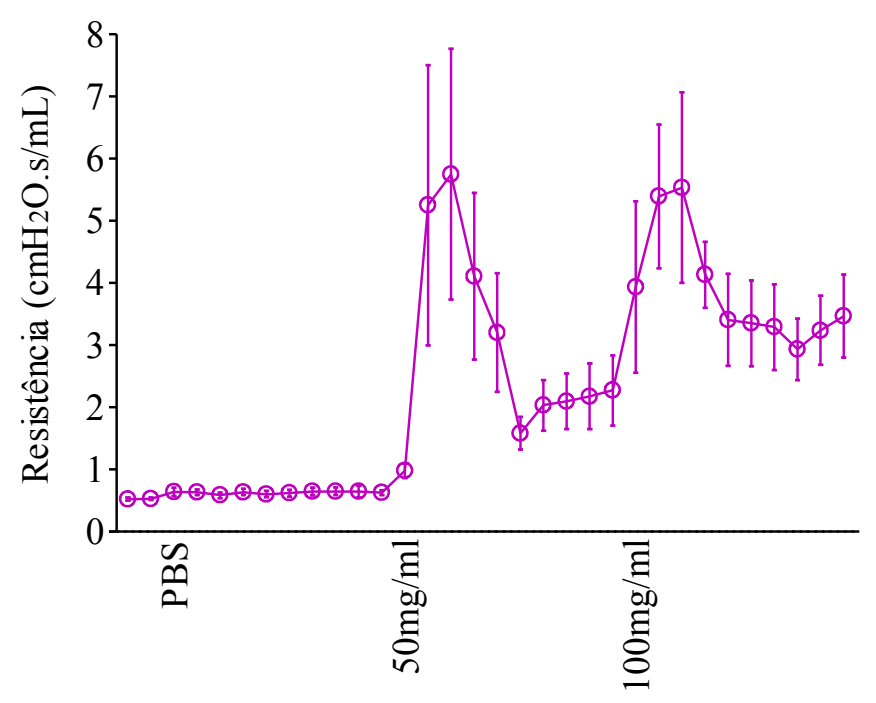

Médias das resistências sequenciais (a cada 30 segundos) pulmonares após nebulização intra-traqueal com PBS e com MCh nas concentrações de 50 e $100 \mathrm{mg} / \mathrm{mL}$.

Figura 33- Medida da elastância das vias aéreas do grupo OVx alérgico+E

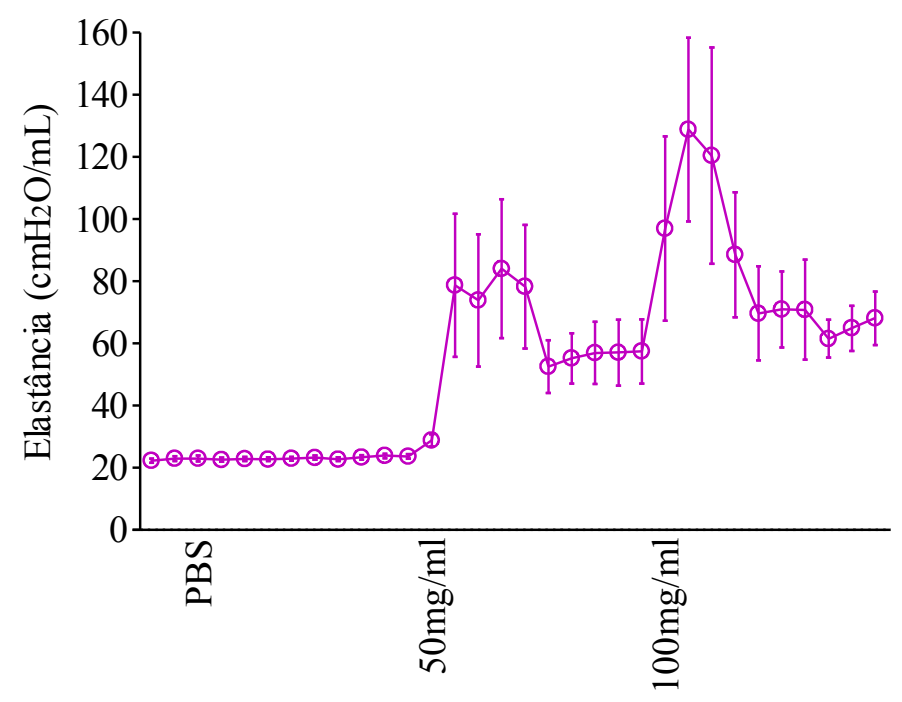

Médias das elastâncias sequenciais (a cada 30 segundos) pulmonares após nebulização intra-traqueal com PBS e com MCh nas concentrações de 50 e $100 \mathrm{mg} / \mathrm{mL}$. 
Figura 34- Medida da resistência das vias aéreas do grupo OVx alérgico+P

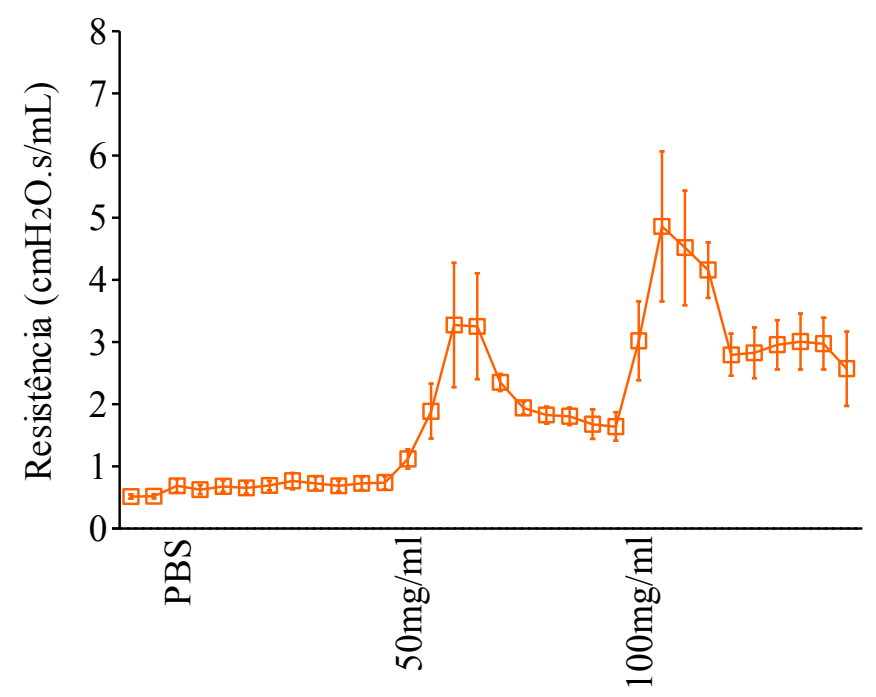

Médias das resistências sequenciais (a cada 30 segundos) pulmonares após nebulização intra-traqueal com PBS e com MCh nas concentrações de 50 e $100 \mathrm{mg} / \mathrm{mL}$.

Figura 35- Medida da elastância das vias aéreas do grupo OVx alérgico+P

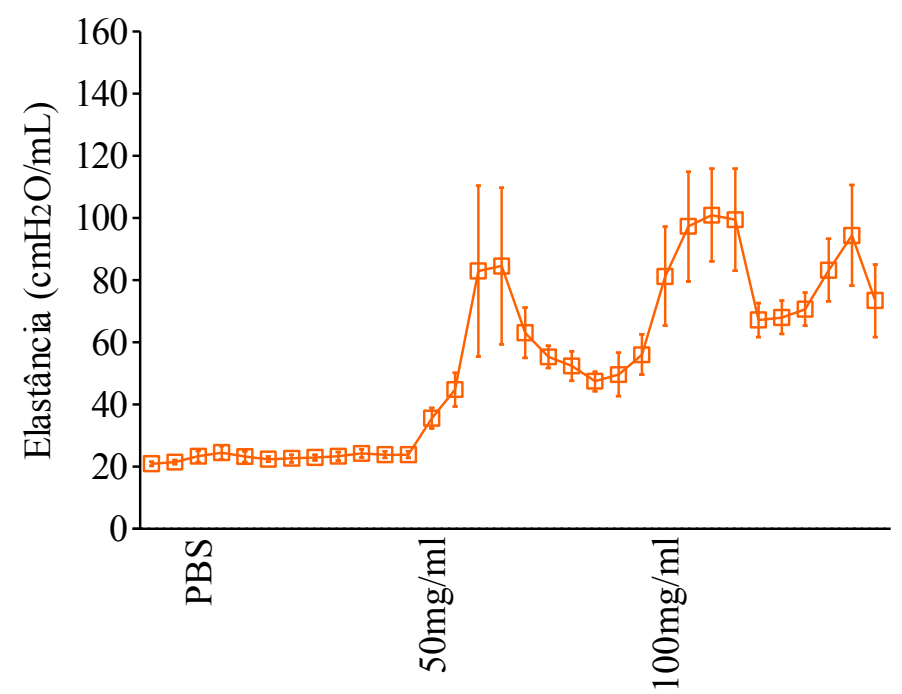

Médias das elastâncias sequenciais (a cada 30 segundos) pulmonares após nebulização intra-traqueal com PBS e com MCh nas concentrações de 50 e $100 \mathrm{mg} / \mathrm{mL}$. 
Figura 36- Medida da resistência das vias aéreas de todos os grupos experimentais

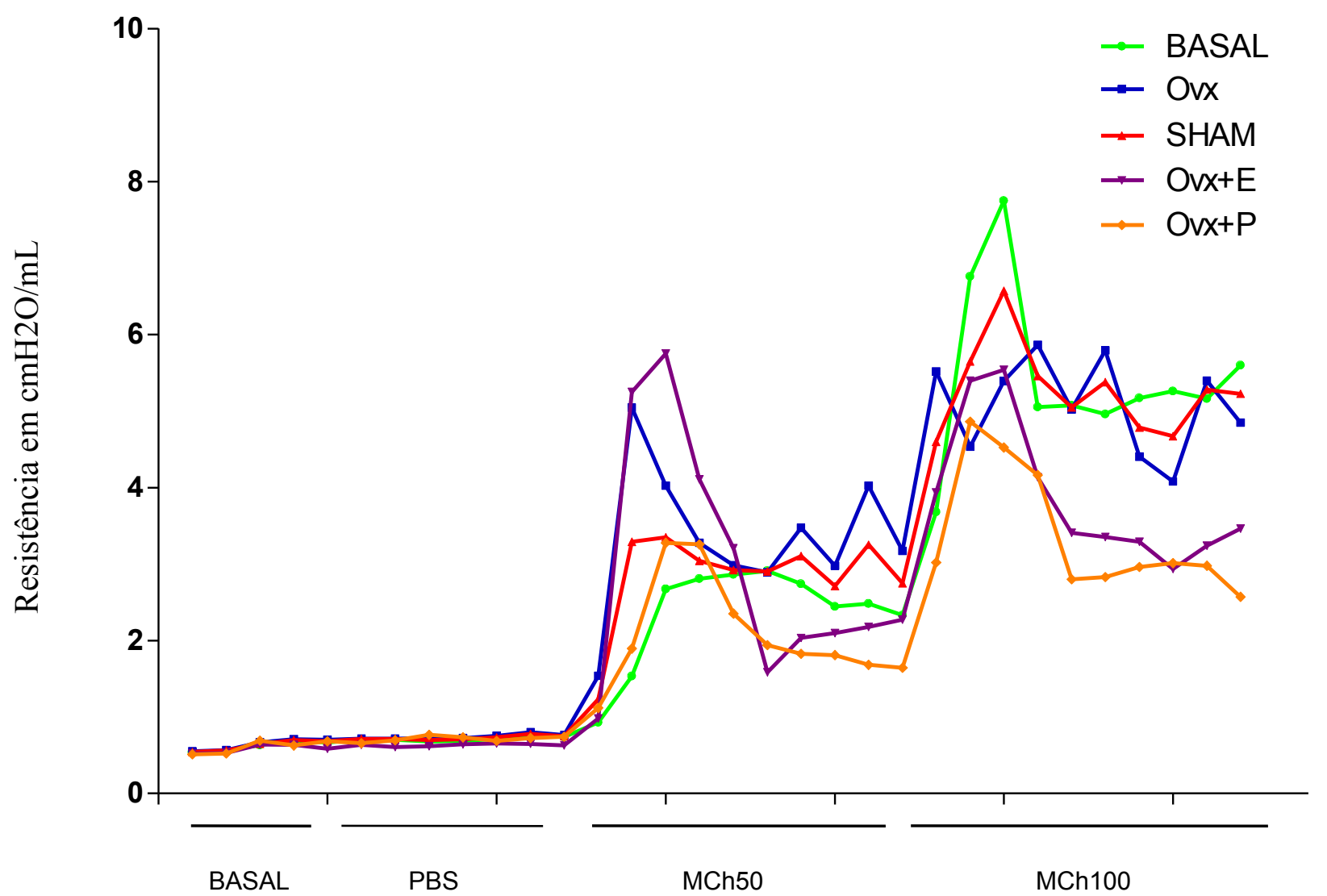

Cada ponto do gráfico representa a média das resistências pulmonares de todos os animais de cada grupo em cada uma dos 32 registros de $\mathrm{R}$ realizados. As duas primeiras medidas de $\mathrm{R}$ são basais ocorridas após o 5 min do animal ser acoplado ao sistema. Os próximos 10 registros ocorrem após o desafio com PBS. Os 10 registros seguintes ocorrem após inalação de $50 \mathrm{mg} / \mathrm{ml}$ de $\mathrm{MCh}$ e os últimas 10 registros após inalação de MCh $100 \mathrm{mg} / \mathrm{ml}$. R calculada para modelo unicompartimental. 


\section{DISCUSSÃO}

Estudos prévios utilizando modelo similar já haviam revelado o papel modulador dos hormônios sexuais femininos na fase aguda da reação alérgica pulmonar em ratas e em camundongos fêmeas. Em linhas gerais, estes estudos avaliaram a magnitude de migração e ativação de células inflamatórias, a expressão de moléculas de adesão, a desgranulação de mastócitos e a geração de citocinas no pulmão de animais alérgicos ovariectomizados. Os resultados indicaram a existência de uma relação entre os níveis circulantes dos hormônios sexuais femininos no momento em que ocorre a sensibilização dos animais ao antígeno e a magnitude da inflamação alérgica pulmonar subsequente (LIGEIRO DE OLIVEIRA et al., 2004; DE OLIVEIRA et al., 2007; LIGEIRO DE OLIVEIRA et al., 2010).

Considerando os dados previamente obtidos com o modelo experimental agudo em conjunto com relatos existentes na literatura de que mulheres apresentam maior prevalência e maior gravidade na asma (ANTUNES et al., 2010; KLINMAN; VERTHELYI, 2000; EDITORIAL DA AMERICAN JOURNAL OF RESPIRATORY AND CELLULAR MOLOLECULAR BIOLOGY, 2008; TAKEDA et al., 2013), de que a asma afeta até 8\% de todas as mulheres grávidas e em idade fértil (TEGETHOFF et al., 2013) e que camundongos fêmeas demonstram reações inflamatórias com maior exuberância do que machos em modelos animais de inflamação alérgica (TAKEDA et al., 2013), direcionamos o estudo à percepção de que os hormônios sexuais femininos poderiam modular a inflamação pulmonar crônica.

A asma como doença crônica determina alterações estruturais que podem comprometer a função pulmonar (AL-MUHSEN et al., 2011; ELIAS, 2000; SHIFREN et al., 2012). Entre elas o remodelamento pulmonar ocupa lugar de destaque.

O remodelamento pulmonar é observado na clínica e leva à uma diminuída resposta à terapêutica farmacológica e ao agravamento progressivo dos sintomas no decorrer da evolução da doença (HAWANI et al., 2010; PASCUAL; PETERS, 2005; KAMINSKA et al., 2009). Os principais achados anátomo-patológicos em pacientes asmáticos são a diminuição da luz das vias aéreas por fibrose subepitelial, aumento da massa da camada muscular lisa das vias aéreas e hiperplasia de células produtoras de muco (ELIAS, 2000; KAMINSKA et al., 2009; SHIFREN et al., 2012). Evidências experimentais mostram a existência de aumento de depósito de colágeno subepitelial, hipertrofia e hiperplasia epitelial das vias aéreas e aumento da produção de muco em ratos e camundongos submetidos ao modelo de estimulação alérgica inalatória crônica à OVA (CURRAN; COHN, 2010; LABONTÈ et al., 2009; PREFONTAINE, 2007a). Desta forma o modelo animal de inflamação pulmonar alérgica 
crônica é útil para os estudos dos mecanismos reguladores do remodelamento pulmonar (LABONTÈ et al., 2009).

O desenvolvimento do remodelamento pulmonar é um dos fatores responsáveis pela maior morbidade da asma. Ele compromete a mecânica ventilatória dos pacientes trazendo prejuízo irreversível à sua função pulmonar (PASCUAL; PETERS, 2005).

A diminuição do calibre interno das vias aéreas provocada pela hipertrofia do epitélio respiratório, pelo aumento das secreções mucoides e pela fibrose, aumenta a resistência das vias aéreas ao fluxo de ar durante a respiração alterando toda a dinâmica da ventilação. O volume aéreo corrente diminui e aumenta o volume residual pulmonar. A maior resistência à entrada de ar nos pulmões durante a inspiração provoca a sensação de "falta de ar" (dispneia) e consequentemente aumenta o esforço respiratório. $\mathrm{O}$ exame espirométrico revela um padrão obstrutivo com diminuição do volume expiratório forçado no primeiro segundo (VEF1). Muitos pacientes nestas condições necessitam de corticoterapia permanente, pois o uso de broncodilatadores já não se faz suficiente para o alívio dos sintomas, uma vez que não apenas a reatividade brônquica compromete o fluxo aéreo, mas o remodelamento o faz através da alteração morfológica da árvore brônquica (ADAMALI et al., 2012).

Atualmente, o uso de glicocorticoides inalatórios é o tratamento recomendado para indivíduos com asma persistente (HAAHTELA et al., 2013). Nestes pacientes, não há períodos de remissão, apenas crises de agravamento, pois as vias aéreas estão constantemente inflamadas (PLUSA, 2009). Os efeitos antiinflamatórios agudos dos glicocorticoides são capazes de retardar a progressão do remodelamento, confirmando assim que a inflamação crônica é a responsável pela progressão do remodelamento das vias aéreas (KAMINSKA et al., 2009).

Durante o processo inflamatório de origem alérgica, mastócitos, eosinófilos, linfócitos Th1 e principalmente LTh2 estão presentes no sítio de inflamação (Para revisão ver: GALLI et al., 2008; LEE et al., 2013). O espectro de mediadores inflamatórios liberados pelas células envolvidas na asma inclui histamina, leucotrienos (LT) C4, LTD4 e LTE4 e prostaglandinas; TNF, IL-2, IL-3, IL-4, IL-5, IL-10, IL-13, fator de crescimento de colônia granulocítica macrofágica (GM-CSF); endotelina-1, óxido nítrico e vários outros (LEE, 2013; KIM et al., 2013). Estes mediadores estão diretamente relacionados aos eventos que levam às alterações da estrutura das vias aéreas a longo prazo. Citocinas características de linfócitos Th2, como a IL-4, IL-5 e a IL-13 são produzidas durante o processo inflamatório agudo e estão envolvidas com a geração da cascata de eventos que levam ao remodelamento brônquico. A IL-13 exibe atividade estimuladora para vários tipos celulares envolvidos na asma, incluindo as células $\mathrm{B}$, 
mastócitos, eosinófilos, células epiteliais pulmonares, fibroblastos e células do músculo liso das vias aéreas (FIRSZT et al., 2013; YANG et al., 2004). Também atua na produção de muco (BOUCHERAT et al., 2013; CURRAN; COHN, 2010). A IL-4 atua como estimuladora da produção de colágeno e fibronectina e está presente tanto na inflamação aguda quanto envolvida no remodelamento das vias respiratórias (BUCETI ; GALLELLI; PELAIA, 2013).

Diversos estudos mostram que os HSF, notadamente os estrógenos, influenciam a produção destas citocinas (CAY; ZHOU; WEBB, 2012; EL-DESOUKI et al., 2013; HAMANO et al., 1998; YANG et al., 2004), no entanto, os dados disponíveis na literatura são díspares e inconclusivos.

Em 1998, Hamano e colaboradores, demonstraram que células mononucleares humanas encubadas com $\beta$-estradiol e progesterona em níveis semelhantes aos que ocorrem durante a gravidez, têm a capacidade de induzir a produção de IL-4 e IL-13 (HAMANO, et al 1998). Desde então, diferentes estudos vem demonstrando resultados conflitantes. El-Desouki e colaboradores mostraram que em modelo murino de inflamação alérgica pulmonar ocorre aumento dos níveis de IL4 e IL-5 no LBA e quando os animais são tratados com estrógenos durante os desafios alérgicos, ocorre redução significativa nos níveis de IL4 e IL-5 no LBA (EL-DESOUKI et al., 2013).

Outro estudo recente mostra que células de linfonodos mediastinais de camundongos fêmeas alérgicas desafiadas com OVA, quando tratadas com antagonista de estrógenos (tamoxifeno) em culturas ex vivo têm a produção de IL-5 e IL-13 reduzidas quando comparadas às células de camundongos alérgicos não tratadas, mostrando que o estrógeno estimula a produção destas duas citocinas (CAI; ZHOU; WOBB, 2012).

Verthelyi ; Klinman avaliaram simultaneamente os níveis séricos de HSF e de geração das citocinas IL-2, IL-4, IL-6, IL-10 in vivo em células do sangue periférico de mulheres em idade reprodutiva. Eles observaram que o número de células capazes de secretar IL-4 no sangue periférico se se correlaciona diretamente com a elevação dos níveis séricos de estrogênio durante o ciclo menstrual. Estes resultados sugerem a participação do estrogênio na modulação da produção de citocinas in vivo (KLINMAN; VERTHELYI, 2000).

Se ampliarmos esta avaliação para estudos envolvendo o efeito do estrógeno sobre outros mediadores químicos indutores de remodelamento e sobre a reatividade das vias aéreas, observaremos ainda mais conflitos de resultados.

Dimitropoulos e colaboradores demonstraram que o tratamento com 17- $\beta$-estradiol em preparações de anéis traqueais de camundongos Balb $\mathrm{C}$ alérgicos à OVA in vitro, prevenia a reatividade do tecido à estimulação com carbacol (DIMITROPOULOS et al., 2008). 
Real et al., compararam 1274 mulheres de 45 a 56 anos de idade e observaram que aquelas com menopausa há pelo menos seis meses e baixos níveis de estrogênio circulante apresentavam redução de VEF1, menor capacidade vital forçada à espirometria e apresentavam mais sintomas respiratórios quando comparadas com aquelas que menstruavam regularmente (REAL et al., 2007).

Muitas mulheres iniciam ou pioram do quadro de asma quando aproximam-se da época da menopausa (REAL et al., 2012),contudo, as informações disponíveis na literatura sobre possíveis mudanças na fisiologia respiratória nas mulheres após a menopausa são muito limitadas e contraditórias. Inúmeras razões poderiam potencialmente contribuir para os resultados discrepantes encontrados na literatura científica. Os níveis de HSF endógenos variam de acordo com a menarca, a fase menstrual, irregularidade menstrual, gravidez, lactação, ou proximidade com a menopausa. Muitas mulheres utilizam hormônios femininos exógenos, como contraceptivos orais, tratamento para infertilidade ou para reposição hormonal. Níveis de hormônios sexuais também podem variar de acordo com fatores metabólicos, tais como a prática de atividade física, obesidade, sensibilidade à insulina e a síndrome do ovário policístico, dificultando ainda mais os estudos em humanos. Além disso, os efeitos dos hormônios sexuais na inflamação, imunidade, ou metabolismo parecem ser complexos, em alguns casos, até mesmo multidirecionais (REAL et al., 2012).

A transição para o período da menopausa implica em uma série de alterações hormonais e metabólicas. Ocorre substancial diminuição da função ovariana e cessa a fertilidade. Os níveis circulantes de estrogênio aumentam num primeiro momento e posteriormente decaem a valores ínfimos. Após a menopausa, as mulheres também se tornam mais resistentes à insulina, e passam a ter risco aumentado para doenças cardiovasculares (REAL et al., 2007).

Estudos anteriores revelaram que a ovarietomia reduz o recrutamento de células inflamatórias para o pulmão em camundongos fêmeas sensibilizadas à OVA após sete dias de remoção dos ovários (modelo de menopausa) submetidos a dez desafios inflamatórios alérgicos. Neste modelo, a remoção dos ovários provoca redução da geração de certas citocinas inflamatórias (IL-5 e IL-10) no LBA (Dissertação de mestrado RODRIGUESSOARES, 2010). Sendo assim, também em modelo crônico de alergia, os hormônios sexuais femininos podem exercer papel modulador da inflamação pulmonar de origem alérgica.

Considerando estas alterações iniciamos a avaliação dos parâmetros de remodelamento pulmonar. Quantificamos o muco extrusado, o teor de colágeno depositado nas vias aéreas, e as dimensões da camada de músculo liso peri-bronquiolar. Avaliamos 
também a hipertrofia do epitélio de revestimento das vias aéreas e morfologia dos bronquíolos distais. Paralelamente investigamos a reatividade ex-vivo de anéis traqueais à estímulo colinérgico com metacolina e a mecânica respiratória.

De maneira a expandir o estudo dos mecanismos subjacentes à indução de remodelamento, no presente estudo investigamos papel dos hormônios sexuais femininos na geração de metaloproteinases de matriz. Estas enzimas agem sobretudo no metabolismo do colágeno (CORRY et al., 2004; MACKLEROY et al., 2013) . Por fim, avaliamos se os achados histológicos de remodelamento e de reatividade refletiam-se em alterações funcionais mecânicas pulmonares nos grupos de animais estudados.

Os experimentos foram conduzidos de modo a minimizar os efeitos da estimulação alérgica aguda e avaliar apenas as alterações estruturais do tecido, assim, o protocolo de desafios alérgicos foi desenhado de modo que o último desafio de broncoprovocação era realizado cinco dias antes dos experimentos.

A primeira etapa do estudo foi padronizar o modelo de alergia pulmonar. Estudos demonstram que três desafios alérgicos já são suficientes para provocar remodelamento nas vias aéreas em camundongos (LABONTÈ et al., 2009; OBERHOLSER, 2009; SHINAGAWA; KOJIMA, 2003), porém, para nos aproximarmos do comportamento da asma, optamos por prolongar a fase de desafios.

Relatos na literatura apontam desenvolvimento de tolerância ao remodelamento quando a estimulação alérgica inflamatória é prolongada, porém os diversos protocolos de indução de remodelamento são variados e divergentes (OBERHOLSER, 2009). Os protocolos que utilizam de três a sete semanas de estimulação alérgica nos pareceram adequados e consistentes para a avaliação dos parâmetros histológicos que desejávamos (ABREU et al., 2011; DI VALENTIN et al., 2008; LEICK et al., 2012), porém, como não existe consenso na literatura, optamos por submeter inicialmente nossos grupos experimentais alérgicos a 9 ou 21 desafios com o antígeno com o intuito de definir o melhor protocolo a utilizar. A partir da observação dos efeitos sobre a produção de colágeno e de muco nestes animais, definiríamos nosso modelo.

Os dados obtidos revelaram que 9 desafios alérgicos inalatórios foram suficientes para provocar alterações teciduais no pulmão compatíveis com a indução de remodelamento das vias aéreas, tais como aumento da produção de muco, aumento de colágeno sob a lâmina basal, hipertrofia epitelial e aumento da camada de fibras musculares lisas das vias aéreas. Nos animais submetidos o protocolo de 21 desafios alérgicos, notamos o surgimento das mesmas alterações, inclusive com maior exuberância, porém, observamos que a ovariectomia 
não interferiu com a indução do remodelamento da árvore brônquica neste protocolo. Uma vez constatado que 9 desafios inalatórios induziram remodelamento, optamos por trabalhar com este modelo, evitando assim, a manipulação de animais por períodos mais prolongados. Vale lembrar que, como o percentual de muco extrusado e o teor de colágeno nas vias aéreas dos animais dos grupos sham-OVx alérgico e nos animais do grupo OVx alérgicos submetidos a 21 desafios não foram significativamente diferentes, enquanto nos animais submetidos a 9 desafios houve significativa diferença, o modelo de 21-D não se mostraria adequado para investigação dos outros parâmetros propostos. Uma possível explicação para este fato é de que a partir de um certo ponto, a estimulação alérgica permanece de tal forma magnificada pelo estímulo continuado, que a proteção oferecida pela ausência dos HSFs é sobrepujada.

Como hipótese, poderíamos propor que o estímulo inflamatório constante provoca stress oxidativo gerando espécies reativas de oxigênio (RAHMAN, 2003; VAN DER VLIET, 2011; VINA, 2011). Visto que está demonstrado que o stress oxidativo interfere com mecanismos reguladores do remodelamento tecidual na inflamação crônica de origem alérgica (POSSA et al 2012, ZHI-HUA YU, et al. 2013). De fato, as espécies reativas de oxigênio, incluindo o ânion superóxido, o radical hidroxila e produtos da peroxidação lipídica são marcadores importantes da resposta inflamatória (RAHMAN, 2003; VAN DER VLIET, 2011; VINA, 2011; ZHI-HUA YU, et al. 2013). Vale ressaltar que existem estudos indicando que o stress oxidativo medeia a indução de lesão tecidual crônica e o remodelamento pulmonar que ocorre na asma (CHANG et al 2013; CHEN et al., 2013; YOO et al., 2013).

Existem evidências de que o efeito pro-inflamatório do estrógeno nos pulmões ocorra indiretamente por meio da modulação que este esteroide exerce sobre hormônios adrenocorticais, notadamente sobre a atividade de receptores para glicocorticoides. Ligeiro de Oliveira demonstrou que ovariectomia reduzia o número de eosinófilos, neutrófilos e células mononucleares no LBA de ratas submetidas à estimulação inflamatória alérgica aguda, e que, tanto o tratamento com estradiol quanto o bloqueio de receptores de glicocorticoides neste mesmo modelo, restaurava os parâmetros inflamatórios (LIGEIRO DE OLIVEIRA et al., 2004). Estes resultados sugerem que o estradiol possui ações pró-inflamatórias na resposta alérgica pulmonar, que parecem ser mediadas, pelo menos em parte, por glicocorticóides endógenos.

Sabe-se que o estrógeno é capaz de diminuir a expressão de receptores de corticosteroides no sistema nervoso central (CAREY et al., 1995; TURNER et al., 1990), e em outros tecidos (RIBOT, 1995). É possível que o efeito anti-inflamatório observado após a 
ovariectomia se dê por conta da maior disponibilidade de receptores teciduais dos hormônios adrenais, aumentando o efeito dos corticóides endógenos. A persistência do estímulo inflamatório, isto é, a persistência dos desafios alérgicos por 21 vezes, poderia estimular a normalização da expressão de receptores corticoides teciduais. Considerando este aspecto, podemos inferir que nos animais submetidos a 21 desafios, mecanismos de compensação ou de adaptação fisiológica podem estar envolvidos com a indução de remodelamento. Nossos dados não permitem indicar quais são os mecanismos envolvidos com a evolução do remodelamento em animais ovariectomizados submetidos a 21 desafios alérgicos, no entanto, nossa percepção é de que a proteção oferecida pelos HSF é limitada e condicional à magnitude do processo inflamatório. Seja como for, os resultados obtidos com o protocolo de 9 desafios alérgicos demonstraram claramente que a ovariectomia afeta o curso do remodelamento, representando portanto, um modelo mais adequado para o estudo da influencia dos HSF na inflamação pulmonar alérgica crônica.

A hiperplasia de células produtoras de muco é um marcador da presença de remodelamento tecidual (CURRAN; COHN, 2010; OBERHOLZER et al., 2009; RACKÉ et al., 2007). No presente estudo o percentual de muco nas pequenas vias aéreas dos animais do grupo OVx-alérgico foi cerca de duas vezes menor que o encontrado no grupo sham OVxalérgico. É digno de nota que os tratamentos dos animais com estrogênio ou com progesterona, separadamente, não interferiram com a produção de muco nesses animais (OVx alérgicos).

Dimitropoulou e colaboradores submeteram camundongos BALB/C fêmeas ovariectomizadas a 6 desafios intra-nasais com OVA e avaliaram diversos parâmetros de remodelamento comparando-as com animais falso-operados. Os autores referem que a ausência dos HSF aumenta os parâmetros inflamatórios, tais como a presença de células no LBA e produção de muco. Ainda neste trabalho, quando os animais são tratados com reposição subcutânea de estrógeno, ocorre o aumento da produção de muco (DIMITROPOULOU et al., 2009).

Antunes et al., compararam as reações teciduais pulmonares de camundongos BALB/C machos, fêmeas intactas e fêmeas ovariectomizadas sensibilizadas e submetidas a três desafios intra-traqueais (IT) com OVA e observaram que alterações teciduais como aumento de colágeno subepitelial e produção de muco eram mais exuberantes nas fêmeas não ovariectomizadas (ANTUNES et al., 2010).

Em outro estudo, Huerta-Yepez e colaboradores, sensibilizaram camundongos machos $\mathrm{BALB} / \mathrm{C}$ e desafiaram com OVA por duas vezes por via intra-traqueal. Os animais 
desenvolveram resposta alérgica pulmonar e aumento da produção de muco. Um outro grupo submetido ao mesmo protocolo recebeu tratamento com estrógeno por via intra-traqueal durante o período de desafios alérgicos. O estudo mostra que o grupo tratado com estrógeno apresentou diminuição da produção de muco (YERTA-YEPEZ et al., 2008).

Tendo em vista as diferentes referencias encontradas na literatura sobre a influencia dos HSF na produção de muco durante desafios alérgicos nas vias aéreas, nossos achados refletem o quanto os resultados experimentais estão fortemente relacionados aos protocolos e linhagens animais utilizadas.

Nossos resultados acerca do aumento da produção de muco nos animais alérgicos estão em linha com os achados anátomo-patológicos em humanos asmáticos. Enquanto em humanos saudáveis menos de $5 \%$ de células epiteliais das vias aéreas são células caliciformes produtoras de muco, naqueles com asma fatal cerca de 20 a $25 \%$ das células possuem este fenótipo (SHIMURA et al., 1996). Análises morfométricas de cortes de pulmão em autópsias de pacientes com asma fatal demonstram um aumento de 20 vezes no número total de goblet cells em vias aéreas periféricas, quando comparados com os de indivíduos controles sem asma (AIKAWA et al., 1999).

Diversos mediadores inflamatórios estão envolvidos com o aumento do número de células produtoras de muco. (YANG et al., 2004). Os mediadores inflamatórios produzidos por células Th2 são os mais comumente relacionados com este efeito, e dentre eles, a IL-13 merece lugar de destaque (CURRAN; COHN, 2010; TEMANN et al., 2007; YANG et al., 2004). A IL-13 é um mediador químico altamente potente que pode promover de maneira eficaz hiperplasia de células produtoras de muco mesmo em níveis reduzidos. Alguns autores afirmam que esta citocina atua através de efeitos diretos no epitélio das vias aéreas (CURRAN; COHN, 2010; TEMANN et al., 2007).

Nossos estudos preliminares demonstraram que a concentração de IL-13 em amostras de explantes pulmonares estão elevados em animais submetidos a 9 desafios alérgicos. Entretanto, a concentração não diferiu entre os grupos OVx alérgico e Sham OVx alérgico. Além disto, o tratamento dos animais com estradiol ou progesterona não alterou o perfil de geração de IL-13. Uma possível explicação para a inserir os HSF como moduladores da produção de muco é que a IL-13 possa exercer mecanismos regulatórios indiretos e menos agudos sobre a produção mucóide.

É interessante notar que o fosfatidilinositol 3-quinase (PI3K) é necessário para a expressão do gene da IL-13 (ATHERTON et al., 2003). Ainda, a fosforilação dos ER- $\beta$ ativa a via de sinalização celular mediada por PI3K (KUMAR et al., 2013). Considerando que não 
encontramos relação entre a o tratamento do animais com estradiol (grupo $\mathrm{OVx}+\mathrm{E}$ ) e a geração de IL-13 durante a inflamação alérgica crônica, é possível que a geração de IL-13 neste modelo não decorra da estimulação direta dos ER- $\beta$ ou ainda, que sua geração seja dependente de uma fonte de co-estimulação.

Embora a IL-13 seja classicamente a citocina mais relacionada com a hiperprodução de muco das vias aéreas inflamadas, diversos outros mediadores exercem influência sobre a produção mucóide. Dentre estes, citocinas como IL-9, IL-1 $\beta$ e a IL-4, além de mediadores lipídicos derivados da atividade a ciclo-oxigenase 2 (COX-2), TNF- $\alpha$ e o fator de crescimento epidérmico (EGF) (LAI; ROGERS, 2010) também podem mediar a geração exacerbada de muco.

O EGF exerce função crítica no crescimento, diferenciação e reparação de células epiteliais das vias aéreas (HACKEL, et al., 1999; BURGEL et al., 2004). Alguns trabalhos demonstram que a estimulação de seus receptores (EGF-R) por agonistas como o TGF- $\alpha$ em células epiteliais das vias aéreas, promovem a diferenciação de células epiteliais em células produtoras de muco - goblet cells. (CURRAN; COHN, 2010; TAKEYAMA et al., 1999;).

Existem dados indicando que o TNF solúvel estimula a hiperplasia de células produtoras de muco após estímulo alérgico (MAILLET et al., 2011). Ainda, esta citocina estimula a transcrição gênica e aumenta a expressão de genes pró-inflamatórios relacionados com a hiperplasia e metaplasia das células produtoras de muco (RAHMAN et al., 2002). O TNF- $\alpha$ também induz secreção de mucina de maneira dose-dependente (SHIMIZU; SHIMIZU, 2012).

Com respeito aos hormônios sexuais femininos, existem dados experimentais indicando que a progesterona favorece a produção de TNF- $\alpha$ em modelo de inflamação pulmonar aguda (LIGEIRO DE OLIVEIRA et al., 2010; MILLER ; HUNT, 1998; RAHMAN et al., 2002).

Trabalhos também demonstram que a progesterona facilita a diferenciação de linfócitos para a linhagem Th2, afetando assim o balanço Th1/Th2 e consequentemente favorecendo o padrão de resposta alérgica (IWATA; MIYAURA, 2002).

Estudos realizados em nosso laboratório demonstraram que a ovariectomia reduz a migração de células inflamatórias aos pulmões em modelo de inflamação alérgica aguda em ratas, e que a reposição de estrógeno nestes animais, aumenta novamente o influxo de neutrófilos, linfócitos e eosinófilos no pulmão a níveis compatíveis com os dos animais alérgicos não ovariectomizados (LIGEIRO DE OLIVEIRA et al., 2004). 
Em nosso estudo, vale ressaltar que animais OVx alérgicos tratados com progesterona não apresentaram qualquer produção de muco. Dados semelhantes podem ser encontrados na literatura. Mitchell e colaboradores, demonstraram em camundongos BALB-C, que em modelo de alergia pulmonar aguda com sensibilização e desafios a partir de antígenos de ácaros de poeira doméstica, o tratamento de animais ovariectomizados com progesterona ao longo do período de desafios alérgicos não provocou produção de muco (MITCHELL et al., 2012). Estas evidências levam ao pensamento de que a presença de ambos HSF (estrógeno e progesterona) seja necessária para que haja aumento da produção de muco decorrente do estímulo alérgico. Sem o estrógeno há reduzida migração de células inflamatórias os pulmões, dentre as quais os neutrófilos, e sem a progesterona não ocorre estimulação para síntese de TNF- $\alpha$ pelas células inflamatórias. Desta maneira, podemos propor que a síntese de TNF- $\alpha$ represente um fator-chave para os eventos moleculares que levam à produção mucoide.

Considerando os nossos dados e beaseados naqueles da literatura podemos admitir que existe portanto, um complexo mecanismo subjacente ao aumento da produção de muco através do estímulo inflamatório crônico. A presença de células inflamatórias no compartimento pulmonar (macrófagos, linfócitos, neutrófilos e etc) traz consigo a geração de mediadores inflamatórios. A complexa interação dos diversos mediadores inflamatórios pode determinar efeitos paralelos, dentre os quais o aumento da produção de mucina e a ativação de receptores de EGF, que por sua vez promovem reprodução e crescimento celular epitelial facilitando a resposta à IL-13, que controla múltiplos estágios na diferenciação e função de células produtoras de muco.

Nossos achados, portanto, apontam que a OVx diminui a hiperplasia de células caliciformes e a produção de muco em animais alérgicos.

Outro parâmetro avaliado como componente do remodelamento foi o colágeno. Em nosso estudo com os animais submetidos a 9 desafios, o grupo OVx-alérgico demonstrou significativa redução do percentual de colágeno nas vias aéreas quando comparado com o percentual obtido nas vias aéreas do grupo Sham OVx alérgico. Nos animais submetidos a 21 desafios, observamos acentuada produção de colágeno nos animais alérgicos, porém não observamos diferença significativa na quantificação de colágeno peribronquiolar entre os grupos OVx alérgico e sham OVx alérgico.

Visto estes resultados, tratamos os animais OVx alérgicos submetidos a 9 desafios com estrógeno ou progesterona. Embora a ovariectomia tenha prevenido o aumento da produção de colágeno, o tratamento de animais ovariectomizados com progesterona (grupo OVx Alérgico+P) levou ao aumento de sua produção (com a média percentual da 
quantificação sendo quase duas vezes maior do que a do grupo Sham OVx-alérgicos). Por outro lado, animais ovariectomizados tratados com estrógeno (grupo OVx-alérgicos $+\mathrm{E}$ ) apresentaram produção de colágeno similar à do grupo basal (Figura 15).

Nossos estudos preliminares mostraram que no LBA, a quantificação de neutrófilos do grupo OVx-alérgico foi o equivalente a $24 \%$ do total de neutrófilos do grupo Sham OVxalérgico (ou cerca de quatro vezes menor). Além disto, quando os animais OVx alergicos foram tratados com estrógeno, a quantificação de neutrófilos no LBA voltou a atingir níveis semelhantes ao do grupo Sham OVx-alérgico. Entretanto, em animais OVx alérgicos tratados com progesterona não observamos neutrófilos no LBA.

Recentes estudos demonstram a concentração de neutrófilos no sítio inflamatório está diretamente relacionada à estimulação da expressão de metaloproteinases de matriz (MMPs) e consequentemente ao maior controle do metabolismo de colágeno. Algumas citocinas próinflamatórias como o TNF- $\alpha$ e a IL- $1 \beta$ e o LPS também estimulam a síntese de MMPs a partir de neutrófilos em cultura (OVERBEEK et al., 2013). É sabido que a progesterona e seu análogo sintético 17-acetato medroxiprogesterona inibem a síntese e a expressão tecidual MMPs em útero de camundongos fêmeas C57Black/6 (WANG et al., 2013). Existem ainda dados indicando que a progesterona medeia o retardo da involução do tecido uterino, que está relacionado à perda de colágeno, após a prenhêz em ratas. (WANG et al., 2013).

Nossos resultados não mostraram diferenças significativas na quantificação da expressão de MMP-2 entre o grupo tratado com progesterona e o grupo basal (figura 22). Já em relação à expressão de MMP-9, o grupo OVx alérgico+P apresentou expressão de MMP-9 duas vezes maior do que a dos grupos OVx-alérgico e Basal. Estes dados vão de encontro ao esperado uma vez que quantificação de neutrófilos no grupo OVx alérgico+P foi nula.

O aumento da expressão de MMP-9 no grupo OVx alérgico+P em relação aos grupos OVx alérgico e Basal, não parece estar relacionado meramente à maior degradação (e consequentemente diminuição) do colágeno, mas ao aumento da sua renovação (turnover) no tecido durante o processo de remodelamento, fato reforçado pela quantificação de colágeno no grupo $\mathrm{OVx}$ alérgico+P, que foi quase três vezes mais elevada que a do grupo $\mathrm{OVx}$ alérgico. O grupo $\mathrm{OVx}$ alérgico+E demonstrou quantificação de colágeno que não foi significativamente diferente da do grupo basal, ou seja, significativamente menor do que a do grupo OVx alérgico.

Concentrações elevadas de MMP-9 são encontradas no tecido pulmonar em algumas doenças caracterizadas por intensa fibrose tecidual, como fibrose pulmonar idiopática (SUGA et al., 2000), fibrose cística (DELACOURT et al., 1995) e enfisema pulmonar. Além disto, 
não apenas neutrófilos, mas macrófagos, células epiteliais e fibroblastos estão envolvidas com a produção de MMPs (PARKS; SHAPIRO, 2001). A expressão de MMP-9 nos pulmões também pode ser induzida por citocinas, fatores de crescimento e espécies reativas de oxigênio e nitrogênio (GARCIA-ROMAN et al., 2010; OKAMOTO et al., 2004). De fato, as espécies reativas decorrentes do stress oxidativo inflamatório são potentes estimulantes da geração de MMPs levando à conversão das pró-MMPs às suas formas ativas (OKAMOTO et al., 2004). Diversos estudos relacionam ainda, a formação de espécies reativas proveniente do NO liberado no ambiente inflamado, à estimulação de genes que afetam a produção de MMPs (MACKLEROY et al., 2013; PITT ; ST. CROIX, 2002; VANDOOREN, 2013).

Os dados obtidos no presente estudo nos remetem à percepção de que o aumento na expressão de MMP-9 no grupo de animais OVx alérgicos tratados com progesterona se relaciona à fibrose peri-bronquica, típica do remodelamento das vias aéreas.

No camundongo, tipicamente, o maior acúmulo de fibras colágenas das vias aéreas distais dispõe-se na região entre a via aérea e seu vaso adjacente (OLBERHOLZER et al., 2009). Neste sentido, diferenças na quantidade e na disposição das fibras colágenas peribronquiolares poderiam interferir com a resposta do tecido das vias aéreas ao processo inflamatório, uma vez que a estrutura da interface entre o vaso e a via aérea está alterada. Esta alteração estrutural pode trazer modificações às interações moleculares entre vaso e via aérea adjacente.

Os mastócitos também participam da deposição de colágeno nas vias aéreas observada na asma. Estudos experimentais revelam que camundongos deficientes de mastócitos não desenvolvem fibrose pulmonar induzida por bleomicina (VEERAPPAN et al., 2013). Dois mediadores provenientes de mastócitos são conhecidamente fibrinogênicos: histamina e angiotensina II.

O fibroblasto é a principal célula envolvida com a gênese da fibrose. Tanto fibroblastos de humanos quanto de ratos expressam receptores para histamina e angiotensina II. Quando ativados, estes receptores promovem secreção de TGF- $\beta 1$ e síntese de colágeno (VEERAPPAN et al., 2013). Desta maneira, a presença de mastócitos ativados na região das vias aéreas é potencial indutora de colágeno. A fibrose subepitelial participa da indução do enrijecimento permanente das pequenas vias aéreas na asma e pode afetar sua contração e seu relaxamento (PINELLI et al., 2009). Tais alterações funcionais podem interferir na morbidade da doença e diminuir a resposta terapêutica à medicações (ACEVES et al., 2008). Desta forma, o aumento da deposição de colágeno nas vias aéreas assume importante papel no agravamento da doença. 
Dentre o contingente de células reconhecidamente relevantes na asma, os eosinófilos ocupam lugar de destaque (para revisão ver: GALLI et al., 2008). Existem dados indicando que camundongos nockout para MMP-2 exibem reduzido de células inflamatórias, notadamente de eosinófilos no lúmen alveolar. Embora o recrutamento permaneça eficiente, é o gradiente de quimiotaxia que se torna diminuído (CORRY et al., 2002). Em nossos experimentos, não encontramos eosinófilos no LBA do grupo $\mathrm{OVx}$ alérgico+P.

Considerando que a ovariectomia preveniu o aumento no teor de colágeno, os dados obtidos acerca da sua deposição nas vias aéreas dos animais alérgicos sugerem que a progesterona exerça efeito relevante na produção de colágeno. De alguma maneira, este hormônio quando presente isoladamente no tecido (sem a presença dos estrógenos) durante o processo alérgico crônico traz repercussões para o metabolismo local do colágeno.

Gilliver et al., demonstraram que a administração contínua de estrógeno subcutâneo é capaz de retardar a cicatrização de ferimentos cutâneos em camundongos machos C57Black/6 e sugere que esta ação se dê através do receptor E $\alpha$ que estimularia a atividade da MMP-2 no tecido cutâneo impedindo a proliferação do colágeno e consequentemente retardando a cicatrização (GILLIVER et al., 2010). Light et al., demonstrou que o tratamento de coelhos machos com estrógeno reduz a expressão de colágeno nos ligamentos articulares de seus membros inferiores (LIGHT et al., 2012). Assim, a ausência de estrógenos (potenciais inibidores da deposição de colágeno) e a presença de progesterona (indutora da deposição de colágeno) favoreceria o aumento da deposição deste elemento no grupo $\mathrm{OVx}$ alérgico+P.

Além disso, poderíamos propor que mediadores inflamatórios e ROS atuem como sinalizadores para o estímulo à expressão de MMP-9, que por sua vez, afetaria o turnover do colágeno na matriz extracelular, provocando em última instancia, fibrose das vias aéreas (aumento de colágeno peri-brônquico).

Com respeito às metaloproteinases, está bem estabelecido que a MMP-2 é expressa constitutivamente em muitos tipos celulares enquanto a expressão da MMP-9 é aumentada na vigência de processos inflamatórios (GUEDERS et al., 2006, OKAMOTO et al., 2004; PIIRILA et al., 2010) ou induzida por fatores de crescimento, citocinas e lipopolissacarídeos (GUEDERS et al., 2006; OKAMOTO et al., 2004).

Além de sua ação direta sobre a degradação de colágeno, as MMPs podem degradar outros componentes da matriz extracelular, incluindo fibronectina, laminina e proteoglicanos (GUEDERS et al., 2006). A atividade proteolítica sobre a matriz altera o arcabouço intercelular e consequentemente interfere com a aderência e a locomoção das células inflamatórias. Ao mesmo tempo, a degradação proteica leva à produção de metabólitos que 
atuam como mediadores inflamatórios que medeiam a sinalização, sobretudo para eventos quimiotáxicos (OPDENAKKER et al., 2001). As MMPs constituem, portanto, influentes componentes da inflamação. Neste contexto é razoável considerar que possam participar no desencadeamento de alterações das vias aéreas as quais podem levar ao remodelamento pulmonar.

Nossos dados reforçam a participação dos hormônios sexuais femininos, notadamente do estradiol o controle da manutenção da matriz extracelular visto que observamos aumento significativo da concentração de MMPs -2 no grupo de animais OVx alérgico tratados com estradiol $(\mathrm{OVx}$ alérgico $+\mathrm{E})$, mas não naqueles tratados com progesterona. Nesse sentido, é possível sugerir que o estradiol seja hormônio específico a facilitar a expressão tecidual de MMP-2 durante a inflamação pulmonar crônica. Reforçando esta percepção, a quantificação do percentual de colágeno no grupo $\mathrm{OVx}$-alérgico+E não diferiu significativamente da observada no grupo Sham OVx-alérgico. Portanto, nossos dados permitem relacionar a fibrose peribrônquica à expressão de MMPs.

Acredita-se que as MMP-2, além de participarem da regulação e do controle do tráfego de células inflamatórias também exercem papel importante na degradação de células inflamatórias pré-apoptóticas presentes no pulmão alérgico (CORRY et al., 2004). Estudos anteriores do nosso grupo revelaram que animais do grupo OVx-alérgico tratados com estradiol (OVx alérgico+E) apresentam número similar de linfócitos, macrófagos, neutrófilos e eosinófilos quando comparados com os quantificados em animais do grupo Sham OVxalérgico (DISSERTAÇÃO DE MESTRADO RODRIGUES-SOARES, 2010). Possivelmente, o aumento da expressão de MMP-2 durante o processo inflamatório crônico, contribua para o influxo de células inflamatórias no pulmão.

A remoção dos ovários preveniu o aumento da expressão de MMP-9 no pulmão dos animais alérgicos (figura 23). O tratamento dos animais alérgicos ovariectomizados com 17 $\beta$ estradiol (grupo OVx-alérgico+E) não alterou os valores de MMP-9 em relação ao grupo OVx alérgico, enquanto o tratamento dos animais ovariectomizados com progesterona produziu concentrações de MMP-9 no pulmão semelhantes a do grupo sham OVx alérgico. Assim, nossos dados revelaram que em relação à MMP-9 é a progesterona, e não mais o estradiol, que exerce efeito modulador sobre sua expressão.

Nossos resultados mostraram que a progesterona influencia produção de colágeno no pulmão de animais submetidos à inflamação pulmonar alérgica crônica provavelmente através da modulação da expressão de MMP-9. 
Embora os mecanismos moduladores do aumento da deposição de colágeno mediada pela MMP-9 não estejam completamente compreendidos, sabe-se que esta metaloproteinase exerce efeito facilitador da migração de células que participam da fibrose (HEISSIG et al., 2010).

É interessante notar que os camundongos knockout para MMP-9 apresentam redução do número de eosinófilos e neutrófilos no LBA. Estes animais também apresentam índice elevado de apoptose nas vias aéreas (CORRY et al., 2004). Vale ressaltar que camundongos knockout para MMP-2 também apresentam redução de células inflamatórias quando submetidos a desafios alérgicos (CORRY et al., 2004). No conjunto estes dados sugerem a participação das metaloproteinases na inflamação pulmonar notadamente sobre a mobilização de células inflamatórias.

Já foi descrito que a IL-13 atua sinergicamente ao TGF $\beta$-1 elevando a concentração de TIMPs em fibroblastos pulmonares humanos (ZHOU et al., 2011). O TGF $\beta-1$ é um mediador pró-fibrótico relacionado ao remodelamento tecidual e particularmente envolvido no desenvolvimento de fibrose subepitelial pulmonar. Biópsias pulmonares de indivíduos com asma fatal demonstram aumento nos níveis de TGF $\beta-1$ em relação a indivíduos normais (VIGNOLA et al., 1997). Sabe-se também que o bloqueio da IL-13 resulta em redução na quantificação de MMP-9 em camundongos alérgicos (YANG et al., 2005). Assim, uma de nossas hipóteses é de que o aumento da liberação de IL-13 durante o processo inflamatório crônico estimularia a produção de MMP-9.

Estudos mostram aumento da espessura da camada muscular peri-bronquiolar em pacientes com asma moderada ou severa (JAMES et al., 2012; MING-XIAO et al., 2013; MUNAKATA et al., 2006; SCHULIGA et al., 2010). Tal aumento pode atingir o triplo da observada em indivíduos não-asmáticos (AMISHIMA et al., 1998).

Neste estudo mostramos o aumento da camada muscular lisa das vias aéreas em camundongos submetidos à 9 desafios alérgicos inalatórios em relação aos animais não manipulados (grupo basal). A remoção dos ovários previne a progressão do aumento da massa muscular peri-bronquiolar (figura 17).

É interessante notar que o aumento da massa muscular peri-bronquiolar não se mostrou, em termos quantitativos, o parâmetro mais exuberante de analise da existência de remodelamento. De fato, os animais do grupo Sham OVx alérgicos apresentaram aumento de cerca de 1,8 vezes em relação ao grupo basal. Entretanto, esta evidencia é de extrema relevância uma vez que um pequeno aumento na musculatura lisa pode gerar grande acréscimo de força contrátil na via aérea (BATES et al., 2009; DONOVAN, 2013). 
Diversos mediadores inflamatórios induzem a proliferação de músculo liso in vitro, dentre eles,os EGF, PDGF e o IGF ocupam lugar de destaque (MUNAKATA et al., 2006). Além destes, também já está bem estabelecida a participação de componentes da matriz extracelular como o colágeno, afibronectina e a laminina e de citocinas IL-8, IL-1 $\beta$, IL-4, IL6, IL-11, IL-13, IL-17 e IL-25 na sinalização molecular cujos efeitos sobre a hipetrofia e a hiperplasia das células musculares lisas nas vias aéreas já foram observados (GOSEINS et al., 2008). Vale lembrar que até o presente momento, não existe consenso científico de que o aumento da massa muscular lisa das vias aéreas leva a um proporcional aumento na força de contração (CHIN et al., 2012; DONOVAN, 2013; LATOURELLE et al., 2002; SILVEIRA et al., 2005).

Considerando o efeito da ovariectomia sobre a quantificação da massa muscular nos animais alérgicos, investigamos os efeitos dos tratamentos dos animais com os hormônios. Os animais tratados com estrógeno apresentaram um aumento da massa muscular peribronquiolar. Estes animais tiveram valores próximos aos do grupo sham OVx-alergicos. Por outro lado, o tratamento dos animais com progesterona ( $\mathrm{OVx}$ alérgico $+\mathrm{P}$ ) elevou a massa muscular à quantificação semelhante a do grupo basal. No conjunto, os resultados obtidos sugerem que o estradiol exerce efeito modulador do aumento da massa muscular das vias aéreas.

Os efeitos do estrógeno quanto à proliferação de fibras musculares lisas podem diferir, dependendo do sítio de atuação. Evidências experimentais mostram que os receptores de estrógenos são capazes de mediar tanto a estimulação quanto a inibição da proliferação de músculo liso vascular (HAGE; OPARIL, 2013; HOGGS et al., 2012; HONGZHU et al., 2012; ZHAO et al., 2013). Já em relação ao músculo liso das vias aéreas, os estudos parecem apontar na mesma direção: os estrógenos estimulam sua proliferação (CAPRA et al., 2003; ESTAMATIOU et al., 2010). É possível que o estímulo à hiperplasia de fibras musculares lisas se dê pela via de sinalização que envolve receptores celulares ativadores de tirosinakinase 1 (TAK1), uma proteína da superfamília da MAP3 kinase que dispara a produção de TGF- $\beta$ e PDGF (PERA et al., 2011).

Interessante notar que miócitos são capazes de liberar diversos mediadores inflamatórios, como GM-CSF, IL-2, IL-5, IL-6, -IL1, IL-12, IL-13, IFN- $\gamma$, eotaxina, IL-8, PDGF, IGF, VEGF, PGE2, PGEF2, PLA2 (BERAIR, et al., 2013). Assim, uma visão mais contemporânea do papel da musculatura lisa no remodelamento das vias aérea permite, portanto, que as células musculares lisas sejam consideradas como verdadeiros imunoefetores não apenas pela sua proliferação, mas também pelo aumento de secreção de citocinas, 
expressão de moléculas de adesão e interação com várias células inflamatórias (Hirst, 2000). Neste contexto podemos supor que o aumento da massa muscular lisa das vias aéreas que ocorre durante o processo inflamatório crônico pode se relacionar direta (por meio do maior potencial de contração muscular) ou indiretamente (por meio da indução do remodelamento) para a contratilidade aumentada na asma (COJOCARU et al., 2008; PINELLI, 2009).

A proliferação do epitélio é classicamente descrita como parte do remodelamento da árvore brônquica nas doenças inflamatórias crônicas das vias aéreas (AMISHIMA et al., 1998, GRÁS et al., 2013; PREFONTAINE, 2007a; PUDDICOMBE et al.., 2000).

Nossa análises microscópicas do remodelamento das vias aéreas mostraram modificação do epitélio respiratório de revestimento dos animais. A espessura do epitélio de animais alérgicos está aumentada em relação ao grupo não alérgico, contudo, não identificamos diferenças significativas entre o grupo sham OVx alérgico e o grupo OVx alérgico (figura 18). O tratamento com estrógeno e progesterona também não trouxeram diferenças na quantificação da espessura do epitélio das vias aéreas em relação aos outros grupos alérgicos.

Em conjunto, com o aumento da musculatura lisa e com a produção exacerbada de muco, o aumento da espessura do epitélio respiratório contribui para a diminuição luminal das vias aéreas durante as crises asmáticas (KAMINSKA et al., 2009). O aumento do epitélio já foi relacionado proporcionalmente à gravidade da doença (AMISHIMA et al., 1998). Também não é incomum a ocorrência de metaplasia escamosa em indivíduos com asma severa (HAMID; PREFONTAINE, 2007b).

$\mathrm{Na}$ asma, o processo inflamatório crônico aumenta a taxa de apoptose entre as células do epitélio respiratório (COHEN et al., 2007). Ainda, produtos tóxicos derivados dos eosinofilos, como a proteina básica principal, podem também causar lesão do epitélio (TEAL et al., 2012). A lesão celular culmina em descamação do epitélio e exposição de terminações nervosas. Admite-se que a exposição das terminações nervosas contribui para o desenvolvimento da hiperreatividade brônquica (COHEN et al., 2007).

A exposição de terminações nervosas sensoriais na submucosa para o lúmen das vias promove respostas reflexas de estímulo à liberação vagal de $\mathrm{ACh}$, levando à broncoconstrição (DEKKERS et al., 2010). Além disso, no epitélio respiratório existe a presença de colinaacetiltransferase, que, portanto, representa uma fonte direta de ACh (PROSKOCIL et al., 2004).

Já foi demonstrado que a ACh estimula a proliferação de células epiteliais brônquicas humanas em cultura. Este efeito ocorre provavelmente por meio da estimulação de receptores 
muscarínicos tipo M1 (METZEN et al., 2003). A ACh também atua como fator quimiotáxico para eosinófilos, monócitos e neutrófilos in vitro . Ainda, diversos outros mediadores inflamatório estão relacionados ao aumento do epitélio respiratório durante o processo inflamatório (GRAS et al., 2013). Assim fatores de crescimento, espécies reativas de oxigênio e nitrogênio, produtos derivados do metabolismo do ácido araquidônico, peptídeos vasoativos e o óxido nítrico podem mediar a indução da proliferação celular e metaplasia epitelial (HAMID; PREFONTAINE, 2007b).

Visto que não observamos influencia dos HSF no espessamento epitelial advindo do processo alérgico crônico, e sabendo que a diminuição da luz das vias aéreas ocorre por múltiplos fatores, decidimos investigar a influencia dos hormônios sexuais femininos no fenótipo da vias aéreas. Para tanto quantificamos o grau de diminuição da luz das vias aéreas distais nos grupos de experimentação.

O grau de remodelamento varia de acordo com o calibre da via aérea (vias aéreas menores possuem maior grau de remodelamento). Uma vez que o perímetro luminal foi comparado com o perímetro da membrana basal da via aérea, as variações individuais de calibre de vias aéreas distais não interferirão nos resultados.

Embora não tenhamos observado modulação significativa dos HSF no grau de espessamento epitelial, a avaliação da morfologia dos bronquíolos distais revela que existe diferença entre a abertura das vias aéreas entre os grupos, provavelmente devidas à outros componentes estruturais. Neste sentido, é possível que o fato do epitélio das vias aéreas constituir um dos primeiros alvos do antígeno neste modelo de inflamação pulmonar alérgica crônica (desafios antigênicos inalatórios), a repercussão da OVx no remodelamento possa ser observada apenas em sua fase inicial.

Como mencionado, a exposição das terminações nervosas pode mediar a hiperreatividade das vias aéreas. No presente estudo mostramos que a OVx interferiu com a reatividade ex-vivo de anéis traqueais frente à metacolina.

Houve elevação da reatividade das vias aéreas dos animais alérgicos, porém a ovariectomia foi capaz de prevenir este aumento (figura 20). O grupo sham OVx alérgico apresentou reatividade mais elevada do que os outros grupos (figura 21). O grupo OVx alérgico $+\mathrm{E}$ apresentou aumento da reatividade em relação aos grupos basal e $\mathrm{OVx}$ alérgico+P, porém sua contração máxima ainda foi cerca de 2,7 vezes menor do que a reatividade apresentada pelo grupo Sham OVx alérgico.

Os mecanismos subjacentes à indução da hiperreatividade das vias aéreas na asma ainda não estão totalmente esclarecidos, porém sabe-se que a broncoconstricção é altamente 
dependente da musculatura lisa peri-brônquica e da parede da via aérea (SEMENOV et al., 2012).

Em nossas avaliações histológicas de remodelamento tecidual, verificamos que o grupo OVx alérgico+E apresentou maior massa muscular peri-bronquiolar do que o grupo basal (cerca de 2 vezes mais) e do que o grupo OVx alérgico+P (cerca de 1,7 vezes mais). $\mathrm{O}$ aumento da camada muscular pode ser a responsável pela maior reatividade observada neste grupo. Por outro lado, o grupo OVx alérgico+P apresentou elevados níveis de deposição de colágeno na matriz extracelular. Desta maneira, podemos supor que neste grupo poderia existir reduzida elasticidade das vias aéreas, o que poderia limitar sua broncoconstricção.

Outra conclusão importante é a de que não apenas a reatividade, mas também a sensibilidade ao estimulo colinérgico dos grupos submetidos à ovariectomia está modificada em relação ao grupo sham Ovx alérgico.

Diversos estudos sugerem que as células envolvidas com a inflamação pulmonar alérgica e com o remodelamento das vias aéreas podem promover aumento da contração do tecido muscular liso (HAMID; TULIC, 2008; MARGULIS et al., 2009; YANG et al., 2004;).

Recentemente, especial atenção tem sido dada à influencia dos receptores para PI3k. Os receptores PI3k tem sido relacionados à regulação da contração do músculo liso (HOOVER et al., 2012). Camundongos knockout para estes receptores demonstram capacidade reduzida de contração da musculatura lisa de traquéia em vigência de estímulos colinérgicos (HOOVER et al., 2012). Sabemos que os receptores de estrógeno tipo $\beta$ atuam estimulando a sinalização celular mediada por PI3K (KUMAR et al., 2013). No conjunto estes dados poderiam sugerir que o estrógeno poderia estimular a contração do músculo liso das vias aéreas através de sua ação sobre os receptores PI3k.

Mediadores inflamatórios deflagrados pela estimulação da progesterona (possivelmente através das ações da MMP-9) poderiam somar-se ao estímulo direto do estradiol ao receptor ER $\beta$ levando à maior sensibilidade e hiper-reatividade do grupo sham OVx alérgico.

Uma vez verificado que existe franca modulação pelos HSF na morfologia das vias aéreas e na sua reatividade ao estímulo farmacológico durante a inflamação pulmonar crônica, resolvemos investigar se a influencia exercida pelos hormônios sexuais femininos no remodelamento das vias aéreas traziam impacto para a função pulmonar nos grupos de estudo. Assim, partimos para a análise da mecânica pulmonar in vivo dos animais submetidos ao processo inflamatório pulmonar crônico. 
A avaliação da mecânica respiratória é uma das formas mais amplamente utilizadas para se estudar função pulmonar. Distúrbios orgânicos que modificam a estrutura normal do tecido pulmonar ou das vias aéreas podem provocar alterações importantes na mecânica respiratória.

Quando o tecido das vias aéreas sofre hipertrofia por exemplo, com consequente diminuição de sua luz, a corrente de ar encontra maior resistência à sua entrada durante a inspiração, comportando-se como uma "obstrução" ao fluxo aéreo. A diminuição da luz das vias aéreas por aumento da contratilidade bronquiolar provoca o mesmo efeito. Quando existe destruição de alvéolos, tal como a que ocorre no enfisema pulmonar, as unidades funcionais pulmonares perdem a sua elasticidade e forma originais impedindo que a pressão negativa da cavidade torácica durante a fase de expiração seja suficiente para expulsar o ar contido nelas. Ocorre um "represamento" de ar nas cavidades alveolares, aumentando o volume residual aéreo pulmonar (o volume de ar que não é expulso durante a expiração) e consequentemente diminuindo o volume de ar circulante durante o processo de respiração, o que chamamos de distúrbio restritivo. É possível mensurar se existe obstrução ou restrição ao fluxo aéreo pulmonar se conhecermos a capacidade pulmonar total (volume total de ar que cabe no sistema respiratório durante a inspiração máxima) e o fluxo aéreo normal (volume de ar por unidade de tempo) durante a inspiração e a expiração.

Diversos equipamentos são capazes avaliar estes parâmetros utilizando a metodologia de medir valores de pressões fluxos e volumes de um indivíduo e compará-los com os valores da média de uma população da mesma espécie, idade, sexo e constituição física (peso, altura e medidas médias de caixa torácica). Para nossa avaliação de mecânica respiratória utilizamos um ventilador mecânico projetado para pequenos animais (camundongos): FlexiVent (SCIREQ ${ }^{\circledR}$, Canadá). O equipamento conta com um software que se vale de modelos matemáticos constituídos para representar o comportamento mecânico durante respiração nestes animais, através da utilização de volumes correntes conhecidos e de medidas das correspondentes pressões nas vias aéreas. Utilizando dados experimentais (pressões, fluxos e volumes) para utilização em modelos matemáticos, são criadas referências (médias préestabelecidas) de fluxo e volumes aéreos para a espécie, gênero e peso dos camundongos. Baseado nestas referencias, o software do ventilador mecânico consegue demonstrar alterações de resistência à entrada de ar (por exemplo em processos obstrutivos) e alterações de capacidade volumétrica aérea total (tal como em processos restritivos).

A resistência $(\mathrm{R})$ de um sistema condutor de gás, pode ser definida como a sua capacidade em resistir ao fluxo do gás através dele. A resistência das vias aéreas pode ser 
definida como a capacidade do sistema respiratório em resistir ao fluxo do ar inspirado (BATES, 2009).

Entende-se por elastância (E), a força de recolhimento elástico do tecido pulmonar de retornar à sua forma original após ter sido "deformado" por uma força (volume de ar). É a variação da pressão $(\mathrm{P})$ pelo volume $(\mathrm{V})$ mobilizado $(\Delta \mathrm{P} / \Delta \mathrm{V})$.

A complacência pulmonar é o inverso matemático da elastância. É a capacidade dos pulmões de se distenderem após aplicada a força exercida por determinado volume de ar. Trata-se da relação entre a variação do volume de ar mobilizado e a pressão para manter o pulmão insuflado $(\Delta \mathrm{V} / \Delta \mathrm{P})$. Quanto maior a complacência, mais distensível é o tecido pulmonar e, portanto, quanto menor a complacência, mais rígido encontra-se o tecido pulmonar (BATES, 2009, MORIYA, 2003).

A inflamação crônica do parênquima pulmonar e das vias aéreas leva a alterações importantes de sua microestrutura (remodelamento). Alterações tais como fibrose, com consequente enrijecimento do tecido e diminuição da complacência das pequenas vias aéreas trazem repercussões para a mecânica ventilatória normal e consequentemente comprometem todo o processo de respiração.

Eventos como edema, excesso de muco ou contração do músculo liso bronquiolar (característicos do remodelamento pulmonar) aumentam a resistência das vias aéreas à entrada do ar, diminuindo o fluxo aéreo. A diminuição da elasticidade do tecido das vias aéreas, tal como ocorre na fibrose (aumento da deposição de colágeno nas vias aéreas) diminui a capacidade de insuflação pulmonar de maneira global.

Tradicionalmente, a avaliação da mecânica pulmonar pode ser realizada através de dois métodos principais: 1- considerando-se o sistema respiratório como um compartimento único, tipo: "tubo e balão" (modelo unicompartimental) ou 2- considerando o sistema respiratório como composto por múltiplos compartimentos que possuem dinâmicas e respostas diferentes: vias aéreas maiores, vias aéreas menores, parênquima pulmonar e etc. (modelo multi-compartimental).

Quando consideramos o sistema respiratório como um único compartimento, ignoramos as sutilezas de comportamento de cada microambiente pulmonar. A resistência nas vias aéreas superiores por exemplo, é muito diferente da resistência nas vias aéreas inferiores, que por sua vez é diferente da resistência nos alvéolos pulmonares (parênquima). Quando consideramos o sistema como um único compartimento, no entanto, estas diferenças não são consideradas e medimos apenas as alterações grosseiras macroscópicas de resistência aérea ao longo de todo o sistema. A vantagem é que se lida com valores mais consistentes. A 
desvantagem é que se perdem diferenças entre as diversas etapas do trajeto aéreo dentro do sistema respiratório.

Para o cálculo de resistência e elastância num modelo unicompartimental, utiliza-se a equação do movimento, representada por:

$$
\mathrm{P}=\mathrm{R} \_ \text {rs. } \mathrm{V}^{\wedge^{\prime}+\mathrm{E} \_r s . \mathrm{V}+\mathrm{P} \_0}
$$

Onde P é a pressão na entrada das vias aéreas, R_rs é a resistência do sistema respiratório, $\mathrm{V}^{\wedge^{\prime}}$ é o fluxo calculado pela derivada do volume, E_rs é a elastância do tecido pulmonar, V é o volume e P_0 é a constante de correção de erros da capacidade residual funcional. Com esta equação, conhecendo-se o volume e a pressão de entrada do ar nas vias aéreas, é possível obtermos valores de resistência e elastância do sistema respiratório de maneira geral (BATES, 1998).

Existem diversos modelos unicompartimentais. Entretanto, o modelo multicompartimental mais empregado nos dias atuais é, também o chamado de modelo de fase constante (HANTOS et al., 1992) que considera os diversos compartimentos distintos do sistema respiratório, nos quais temos diferentes resultados para as pressões exercidas por um mesmo volume de ar e fluxos diferenciados devido às diferentes composições dimensões estruturais de cada ambiente. O modelo de fase constante modela a impedância do sistema respiratório, separando a ação do Para o cálculo de resistência e elastância do parênquima pulmonar e das vias aéreas separadamente, utilizando-se a seguinte equação:

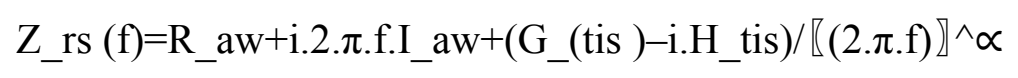

Onde Z_rs (f) é a impedância da via aérea do sistema respiratório em função da freqüênciafrequência, $R_{-}$aw é a resistência das vias aéreas (a resistência somente dos tubos e não dos tecidos), i é a unidade imaginária, f é a freqüênciafrequência, I_aw é a inertância das vias aéreas, G_(tis )caracteriza a dissipação de energia no tecido pulmonar (resistência do tecido pulmonar), H_tis caracteriza a energia acumulada no tecido pulmonar (elastância do tecido pulmonar) e $\alpha=2 / \pi \cdot \arctan \left(\mathrm{H}_{-}\right.$tis/G_tis $)$onde $\arctan$ é o arco-tangente.

$\mathrm{O}$ cálculo de $\mathrm{R}$ e $\mathrm{E}$ no modelo multicompartimental é mais complexo pois envolve mais variáveis, e portanto, são sujeitos a um maior erro em relação à média, consequentemente com ele existe menor sensibilidade para verificar diferenças significativas entre indivíduos. 
O FlexiVent ventilador para pequenos animais empregado nessa pesquisa realiza manobras que possibilitam a realização é capaz de cálculos dealcular resistência e elastância através de ambos os modelos, contudo, em nosso estudo, optamos por realizar os cálculos utilizando o modelo unicompartimental, por ser mais simples e consequentemente oferecer parâmetros mais robustos de alteração da mecânica ventilatória geral.

Para controle dos resultados obtidos, o software do fFlexiVent utiliza um coeficiente de determinação (COD - do inglês Coefficient Of Determination) de ajuste do modelo matemático. O sistema possui um "controle de qualidade" baseado no algoritmo experimental. Ou seja, o COD avalia se o modelo foi aplicado corretamente. Este parâmetro é dado em forma numérica. Um COD com valor de 1 representa uma concordância de $100 \%$ entre os dados obtidos experimentalmente e o ajuste na aplicação do modelo matemático. Caso ocorra alguma interferência durante o experimento e o modelo matemático não seja aplicado de forma correta, este COD assume um valor mais baixo, então os dados gerados de resistência e elastância são acusados como "inválidos". Por exemplo, se durante a aplicação de um volume inspiratório pré-determinado, o animal anestesiado tem uma ventilação espontânea, então o modelo matemático não se ajusta adequadamenteaplica, pois a resposta esperada para o volume empregado deveria ser somente a pressão devida ao comportamento passivo do sistema, com isso e o valor do COD abaixa.

O valor aceitável de COD varia para cada modelo utilizado. Para cálculos considerando-se o modelo unicompartimental, o valor mínimo do COD é 0,95 e para o modelo de fase constante é 0,90 . O valor é mais baixo para o modelo de fase constante, dada sua maior variação e complexidade. Quanto maior o número de variáveis para o cálculo, maior é variação de COD (ajuste do resultado final) aceitável. Portanto, todos os valores de resistência e elastância apresentados em nossos resultados referem-se somente aos CODs válidos (superiores aos valores mínimos aceitáveis para o modelo utilizado). Esta condição criteriosa permite excluir resultados gerados fora das condições experimentais ideais, tornando mais fidedignos os valores finais encontrados.

Não utilizamos drogas bloqueadoras neuro-musculares para acoplar os animais ao ventilador mecânico, pois não era possível a monitoração minuciosa dos parâmetros vitais do equipamento utilizado eram frágeiss animais. Era desejável ter certeza que o animal estava vivo ao final do experimento para validar os resultados. A respiração fisiológica de um camundongo C57BL/6 pode variar de 300-500 ciclos/minuto (CARD et al., 2006; FARRAJ et al., 2010; MILTON et al., 2011). Em nosso estudo, programamos o ventilador mecânico para utilizar uma frequência respiratória de 450 ciclos por minuto em animais anestesiados com 
solução de cetamina e xilazina. Este protocolo de anestesia e ventilação garantia que o animal não entrasse em ventilação espontânea e saísse do experimento com vida (DIMITROPOULOU, et al., 2009; PINELLI et al., 2009; JONASSON et al., 2009; FARRAJ et al., 2010; FRUSH et al., 2011; RIESENFELD et al., 2010; SHALABY et al., 2010; TOMIOKA et al., 2002).

Para chegarmos às concentrações ideais de Mch, nas quais observássemos suficiente uniformidade de resultados, testamos uma faixa de seis concentrações diferentes em três ordens de grandeza: 1, 3, 10, 30, 100, $300 \mathrm{mg} / \mathrm{ml}$. Observamos que os resultados mais uniformes estavam entre 50 e $100 \mathrm{mg} / \mathrm{ml}$. Optamos por utilizar estas duas concentrações como referencia.

De forma geral, quando se utilizam muitas concentrações de Mch começam a ocorrer complicações no experimento, tais como acúmulo de líquido na cânula endotraqueal acoplada ao ventilador mecânico (tanto metacolina quanto secreções do animal), que promove per se um aumento da resistência do sistema interferindo com a mensuração da resistência real do sistema respiratório do animal.

Mesmo padronizando uma metodologia pautada em respeitadas referencias bibliográficas e em observações consistentes de resultados coerentes, os dados que obtivemos não refletiram diferenças significativas na mecânica ventilatória entre os grupos de experimentação. (sham-OVx alérgico, OVx alérgico, OVx alérgico + E e OVx alérgico $+\mathrm{P}$ ). Entretanto, notamos que existe diferença significativa entre todos os grupos alérgicos e o grupo não alérgico (Grupo naïve), o que valida nosso método.

Uma possibilidade é a de que as diferenças de remodelamento observadas entre os grupos de experimentação durante a avaliação histológica, não sejam suficientes para produzir diferenças fisiológicas na ventilação. Mecanismos compensatórios entrariam em jogo para a adaptação fisiológica, uma vez que o processo inflamatório induzido experimentalmente é crônico, oferecendo tempo para a adaptação do sistema respiratório. Em nosso protocolo experimental, utilizamos o tempo mínimo suficiente para produzir alterações morfológicas no tecido atribuídas ao processo inflamatório crônico. É possível que, embora as alterações morfométricas fossem claramente demonstradas nos estudos histológicos, as mesmas não sejam suficientes para produzir repercussão funcional diferente entre os grupos, ou seja, as diferenças existem mais não alterariam a função pulmonar a um nível mensurável com as ferramentas disponíveis.

A escolha pelo modelo unicompartimental também pode ter influenciado na falta de diferença significativa entre os resultados de cada grupo. Embora torne o cálculo mais simples 
e menos sujeito à desvios-padrão, este modelo ignora importantes diferenças entre os microambientes pulmonares, uniformizando (e provavelmente compensando) as possíveis diferenças de valores de resistência e elastância existentes nos diferentes compartimentos do sistema respiratório. Em nossos estudos histológicos, observamos claramente que quanto menor o calibre da via aérea, maior é a reação ao remodelamento pulmonar (hipertrofia epitelial, fibrose e dimuinuição da luz). Sabemos que a fibrose diminui consideravelmente a elastância complacência do sistema e aumenta a sua resistência. Grandes discrepâncias entre as pressões nos compartimentos de vias aéreas superiores (mais calibrosas e portanto menos susceptíveis ao remodelamento) e inferiores (menos calibrosas e com maior comprometimento funcional) culminariam por mascarar um aumento do valor de $\mathrm{R}$ nas vias aéreas inferiores, sabotando mascarando os resultados.

Outra possibilidade que não pode ser deixada de lado, é a que o método utilizado (ventilador mecânico para pequenos animais) não seja sensível o suficiente para captar alterações mais sutis da ventilação pulmonar in vivo.

Há que se considerar também, a influencia da parede corporal nas avaliações de diferenças funcionalmente sutis entre os grupos. Em alguns estudos os autores perfuram o diafragma do animal durante o experimento no ventilador mecânico a fim de igualar a pressão para que não haja interferência da caixa torácica na mecânica pulmonar (JOHNSTON et al., 2008; JONASSON et al., 2009a; JONASSON et al., 2009b; SWEDIN et al., 2010). É plausível a hipótese de que o estudo da mecânica respiratória com a caixa torácica aberta apresente valores mais preditivos para a avaliação do tecido pulmonar e das vias aéreas, uma vez que a expansão do tecido pulmonar não sofreria restrição pelo arcabouço ósseo da caixa torácica.

Em resumo, o estudo da mecânica pulmonar para este protocolo experimental ainda carece de uma padronização mais minuciosa, que permita a demonstração da diferenciação funcional entre grupos que sabidamente apresentam diferenças morfológicas e de reatividade de seus tecidos pulmonares. 


\section{CONCLUSÕES:}

$\rightarrow$ Os hormônios sexuais femininos exercem influencia sobre o remodelamento e a reatividade das vias aéreas no modelo murinho de inflamação pulmonar alérgica crônica.

$\rightarrow$ Os hormônios sexuais femininos exercem influencia sobre a expressão tecidual pulmonar de metaloproteinases 2 e 9 .

$\rightarrow$ É possível que alguns dos efeitos dos hormônios sexuais femininos sobre o remodelamento das vias aéreas sejam resultantes de sua modulação sobre a expressão tecidual de metaloproteinases de matriz extracelular.

$\rightarrow \mathrm{O}$ estrógeno parece ser o hormônio sexual feminino envolvido com a mediação da responsividade do músculo liso traqueal.

$\rightarrow$ As alterações estruturais provocadas pelo remodelamento nas vias aéreas não modificaram a resistência e a elastancia total das vias aéreas no modelo em nosso modelo de inflamação alérgica crônica. 


\section{REFERÊNCIAS*}

ACEVES, S.S.; BROIDE, DH. Airway Fibrosis and Angiogenesis due to Eosinophil Trafficking in Chronic Asthma., Curr Mol Med., v. 8(5), p. 350-358, 2008. 8

ADAMALI, H.I.; MAHER, M.T. Current and novel drug therapies for idiophatic pulmonary fibrosis. Drugs Des. Devel Ther. V.6, p. 261-272, 2012.

ABRAMSON, A. Risk factors for asthma among young adults in Melbourne, Australia. Respirology, v.1, n.4, p. 291-7, 1996.

ABREU, S.C.; ANTUNES, M.A.; MARON-GUTIERREZA, T.; CRUZ, F.F.; CARMO, L.G.R.R.; ORNELLAS, D.S.; CARREIRA-JUNIOR, H.; A, AB`ISABER, A.M.; C, PARRA, E.R.; CAPELOZZI, V.L.; MORALES, M.M.; ROCCO, P.R.M. Effects of bone marrow-derived mononuclear cells on airway and lung parenchyma remodeling in a murine model of chronic allergic inflammation. Respiratory Physiology Neurobiology., v.175, p. 153-163, 2011.

AIKAWA, T.; SHIMURA, S.; SASAKI, H.; EBINA, M.; TAKISHIMA, T. Marked Goblet Cell Hyperplasia with Mucus Accumulation in the Airways of Patients Who Died of Severe Acute Asthma Attack. Chest., v. 101, n. 4, p. 916-921, 1992.

ALMQVIST, C.; WORM, M.; LEYNAERT, B. Impact of gender on asthma in childhood and adolescence: a GA²LEN review. Allergy, v.63, p. 47-57, 2008.

AL-MUHSEN, S.; JOHNSON, R.; HAMID, Q. Remodeling in asthma., J. Allergy Clin. Immunol., v. 128, p. 451-462, 2011.

AL-RAMLI, W.; PRE'FONTAINE, D.; CHOUIALI, M.F.; MARTIN, J.G.; OLIVENSTEIN, R.; HAMID, Q.; LEMIE'RE, C. Th17-associated cytokines (IL-17A and IL-17F) in severe asthma., J. Allergy Clin. Immunol. v. 123, n. 5, p. 1185 - 1187, 2009.

AMERICAN LUNG ASSOCIATION. Trends in Asthma Morbidity and Mortality. Ed. American Lung Association Epidemiology and Statistics Unit Research and Program Services Division. 2011.

AMISHIMA, M.; MUNAKATA, M.; NASUHARA, Y.; SATO, A.; TAKAHASHI, T.; HOMMA, Y.; KAWAKAMI, Y. Am J Respir Crit Care Med., v. 157, p. 1907-1912, 1998.

AMMIT, A.J. et al. ; The role of mRNA stability in airway remodelling. Pulm. Pharmacol. Ther., v.18, p.6, p. 405-15, 2005.

*De acordo com:

ASSOCIAÇÃO BRASILEIRA DE NORMAS TÉCNICAS. NBR 6023: informação e documentação: referências: elaboração. Rio de Janeiro, 2002. 
ANDERSON, M.; HEDMAN, L.; BJERG, A.; FORSBERG, B.; LUNDBACK, B.; RONMARK, E. Remission and persistence of asthma followed from 7 to 19 years of age. Pediatrics. V. 132, p. e435-e442, 2013.

ANTUNE, M.A.; ABREU, S.C.; SILVA, A.L.; PARRA CUENTAS, E.R.; AB'SABER, A.M.; CAPELOZZI, V.L.; FERREIRA, T.P.T.; MARTINS, M.A.; SILVA, P.M.R.; ROCCO. P.R. Sexspecific lung remodeling and inflammation changes in experimental allergic asthma. J Appl Physiol., v. 109, p.855-863, 2010.

ASAI, K. Gender differences in cytokine secretion by human peripheral blood mononuclear cells: role of estrogen in modulating LPS-induced cytokine secretion in an ex vivo septic model. Shok, v. 16, n.5, p.340-3, 2001.

ASTHMA SOCIETY OF CANADA - STATISTICS, 2012 . Disponível em: [http://www.statcan.gc.ca/pub/82-625-x/2011001/article/11458-eng.htm. Acesso em: 25.06.2013.

AUGER, J.; JOUANNET, P. Age and male fertility: biological factors. Rev. Epidemiol. Sante Publique, v. 1, p. 38-42, 2005.

AZIZ, K. E.; WAKEFIELD, D. Modulation of endothelial Cell Expression of VCAN-1 by $\beta$ Estradiol, Progesterone, and Dexametasone. Cell. Immunol., v. 167, p. 79-85, 1996.

BALZANO, G. Asthma and sex hormones. Allergy. v. 56, p. 13-20 , 2001.

BECKER, E. L. In vitro Studies of Immunologically induced secretion of mediators from cells and related phenomena. Adv. Immunol., v.17, p. 93, 1973.

BATES, J. H. T.; BULLIMORE, S. R.; POLITI, A. Z. ; SNEYD, J.; ANAFI, R. C.; LAUZON, A. M. Transient oscillatory force-length behavior of activated airway smooth muscle., Am. J. Physiol. Lung Cell. Mol. Physiol., v.297, p. L362-L372, 2009.

BERAIR, R.; SAUNDERS, R.; BRIGHTLING, C.E.; Origins of increased airway smooth muscle mass in asthma. BMC Medicine., v.11, p. 145-151, 2013.

BEYNON, H.L. ; GARBETT, N. D.; BARNES, P. J. Severe premenstrual exacerbations of asthma: effect of intramuscular progesterone. The Lancet, v.13, n.2 (8607), p. 370-2, 1988.

BIRNBAUN, A. Direct and indirect costs of asthma to an employer. J. Allergy Clin. Immunol., v.109, n. 2 , p. 264-270, 2002.

BODEL, P. Anti-inflammatory effects of estradiol on human blood leukocytes. J. Lab. Med., v. 80, n.3, p. 373-84, 1972.

BOUCHERAT, O.; BOCZKOWSKI, J.; JEANNOTTE, L.; DELACOURT, C. Cellular and molecular mechanisms of goblet cell metaplasia in the respiratory airways., Experimental Lung Research., v.39, p.207-216, 2013. 
BOUSQUET, J.; JACOT, W.; VIGNOLA, A.M.; BACHERT, C.; VAN CAUWENBERGE, P. Allergic rhinitis A disease remodeling the upper airways? J. Allergy and Clin. Immunol., v. 113, n.1, p. 43-49, 2004.

BRADFORD, M. M. A rapid and sensitive method for the quantitation of microgram quantities of protein utilizing the principle of protein-dye binding. Anal. Biochem., v.72, p. 248-254, 1976.

BRANNAN, J.D.; LOUGHEED, M.D.

Airway hyperresponsiveness in asthma: mechanisms, clinical significance, and treatment. Front Physiol., v.10 (3), p.460, 2012.

BRIGHTLING, C. E.; SYMON, F.A.; BIRRING, S.S.; BRADDING, P.; PAVORD, I.D.;

WARDLAW, A.J. Th2 Cytokine expression in bronchoalveolar lavage fluid T lymphocytes and bronchial submucosa is a feature of asthma and eosinophilic bronchitis. J. Allergy Clin. Immunol., v.110, p. 899-905, 2002.

BURGER, D; DAYER, J.M. Cytokines, acute-phase proteins, and hormones: IL-1 and TNFalpha production in contact-mediated activation of monocytes by T lymphocytes. Ann. N. Y. Acad. Sci., v.966, p. 464-73, 2002.

CAMORETTI-MERCADO, B. Targeting the airway smooth muscle for asthma treatment., Translational Research., v. 154, p.165-174, 2009.

CAPRA, V.; HABIB, A.; ACCOMAZO, M.R.; RAVAS, S.; CITRO, S.; TOLEDANO, S.L.; NICOSI, S.; ROVATI, E.G.; Thromboxane prostanoid receptor in human airway smooth muscle cells: a relevant role in proliferation. European Journal of Pharmacology., v. 474, p. 149 - 159, 2003.

CARD, J.W.; CAREY, M.A.; BRADBURY, J.A.; DEGRAFF, L.M.; MORGAN, D.L.; MOORMAN, M.P.; FLAKE, G.P.; ZELDIN, D.C. Gender Differences in Murine Airway Responsiveness and Lipopolysaccharide-Induced Inflammation. J. Immunol., v. 1; n. 177, p. 621-630, 2006.

CAREY, M.A. It's all about sex: gender, lung development and lung disease. Trends Endocrinol. Metab., v.18, n.8, p. 308-13, 2007.

CAY, Y.; ZHOU, J.; WEBB, D.C. Estrogen stimulates Th2 cytokine production and regulates the compartmentalisation of eosinophils during allergen challenge in a mouse model of asthma. Int Arch Allergy Immunol., v. 158(3), p. 252-260.2012

CENTER FOR DISEASE CONTROL AND PREVENTION - CDC, 2013. Disponível em: http://www.cdc.gov/. Acesso em: 18.12.2012.

CHANDLER M. H. Premenstrual asthma: the effect of estrogen on symptoms, pulmonary function, and beta 2-receptos. Pharmacotherapy, v.17, n. 2, p. 224-34, 1997. 
CHANG, C.C.; TANG, C.K.; LIN, C.S.; Effects of Diosgenin on Myometrial Matrix Metalloproteinase-2 and -9 Activity and Expression in Ovariectomized Rats. Int J. Biol. Sci., v. 7(6), p.837-847, 2013.

CHANG, A.S.; LINDERHOLM, A.; LISAFRANZI, A.; NICHOLASKENYON, A.; HELMUTGRASBERGER, B.; HARPER, R. Dual oxidase regulates neutrophil recruitment in allergic airways., Free Radical Biology and Medicine., v. 65, p. 38-46, 2013.

CHEN H. Airway hyperresponsiveness: from molecules to bedside selected contribution: TNF- $\alpha$ modulates murine tracheal rings responsiveness to G-protein- coupled receptor agonists and $\mathrm{KCl}$. J. Appl. Physiol., v. 95, p.864-72, 2003.

CHEN, Q.; JIN, M.; YANG, F.; ZHU, J.; XIAO, Q.; ZHANG, L. Matrix Metalloproteinases: Inflammatory Regulators of Cell Behaviors in Vascular Formation and Remodeling., Mediators of Inflammation., v. 2013, n. 928315, p. 1- 14, 2013.

CHHABRA, S. K. Premenstrual Asthma. Indian J. Chest Dis. Allied. Sci., v. 47, p. 109- 116, 2005.

CHIN, L.Y.; BOSSÉ, Y.; PASCOE, C.; HACKETT, T.L.; SEOW, C.Y.; PARÉ, P.D. Mechanical properties of asthmatic airway smooth muscle. Eur. Respir. J., v.40, n. 1, p. 45-54, 2012.

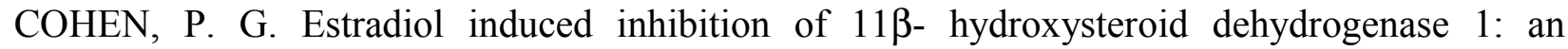
explanation for the postmenopausal hormone replacement therapy effects. Medical Hypotheses, v. 64 , p. $989-991.2005$.

COHEN, L.; XUEPING, E.; TARSI, J.; RAMKUMAR1, T.; HORIUCHI, T.K.; COCHRAN, R.; DEMARTINO, S.; SCHECHTMAN, K.B.; HUSSAIN, I.; HOLTZMAN, M.J.; CASTRO, M. Epithelial cell proliferation contributes to airway remodeling in severe asthma. Am. J. Respir. Crit. Care Med., v. 176, p. 138-145, 2007.

COLLINS, L.C.; PEIRIS A. Bronchospasm secondary to replacement estrogen therapy. Chest, v.104, p. 1300-1302. 1993.

COMINO, E. J. The Australian National Asthma Campaign: effects of public education activities based on mass media. Am. J. Prev. Med., v.13, n.4, p. 251-6,1997.

CORRY, D.B.; KISS, A.; SONG, L.Z.; SONG, L.; XU, J.; LEE, S.H.; WERB, Z.;

KHERADMAND, F. Overlapping and independent contributions of MMP2 and MMP9 to lung allergic inflammatory cell egression through decreased CC chemokines., The FASEB Journal., v. 10, p. 03-14, 2004.

CURRAN, D.; COHN, L. Advances in Mucous Cell Metaplasia., Am. J. Respir. Cell. Mol. Biol. v. 42, p. 268-275, 2010. 
DATA SUS 2013 Statistics - Disponível em: http://www.datasus.gov.br. Acesso em: 02.03.2013.

GINA 2012 Statistics - Global Iniciative for Asthma, 2012. Disponível em: www.ginabrasil.com.br. Acesso em 28.10.2012.

DEKKER, B.G.; BOS, I.S.; GOSENS, R.; HALAYKO, A.J.; ZAAGSMA, J.; MEURS, H. The integrin-blocking peptide RGDS inhibits airway smooth muscle remodeling in a guinea pig model of allergic asthma. Am. J. Respir. Crit. Care Med., v. 15, n.181, p. 556-65. 2010.

DELACOURT, $\quad$ C.; $\quad$ BOURGEOIS, M.L.; $\quad$ D'ORTHO, M.P.; $\quad$ DOIT, C.; SHEINMANN, P.;NAVARRO, J.; HARF, A.; HARTMANN, D.J.; LAFUMA, C. Imbalance between $95 \mathrm{kDa}$ type IV collagenase and tissue inhibitor of metalloproteinases in sputum of patients with cystic fibrosis. Am. J. Respir. Crit. Care Med., v.152, n.2, p.765-74, 1995.

DELMAS, M.C.; FUHRMAN, C. Impact of gender on asthma in childhood and adolescence: a GA2LEN review2010. Revues de Maladies Repiratoires., v. 27, p. 151-159, 2010.

DE OLIVEIRA, A. P. L.; DOMINGOS, H. V.; CAVRIANI, G.; DAMAZO, A. S.; DOS SANTOS FRANCO, A. L.; OLIANI, S. M.; OLIVEIRA-FILHO, R. M.; VARGAFTIG, B. B.; DE LIMA, W. T. Cellular recruitment and cytokine generation in a rat model of allergic lung inflammation are differentially modulated by progesterone and estradiol. American Journal of Physiology. Cellular Physiology, v. 293, p. 1120-8, 2007.

DESHPANDE, R. R. The anovulation in female mice resulting from postnatal injections of estrogen is correlated with altered levels of CD8+ lymphocytes. Am. J. Reprod. Immunol., v.38, n.2, p.114-20, 1997.

DESWAL, A. Cytokines and cytokine receptors in advanced heart failure: an analysis of the cytokine database from the Vesnarinone trial (VEST)., Circulation, v. 4, n. 3, s.16, p. 2055-9, 2001.

DILLARD, G.M.; BODEL, P. ; KAPLAN S.S.; Anti-inflamatory effects of estradiol on human blood leucocytes. Journal Lab. Clin. Med., v.80, p. 373-84, 1972.

DIMITROPOULOUS, C. et al, Estrogen replacemment therapy prevents airway disfunction in a murine model of allergen-induced asthma. Lung. V. 187, n.2, 2009.

DIMITROPOULOU, C.; Drakopanagiotakis, E.; Chatterjee, A.; Snead , C.; Catravas, J.D. Estrogen Replacement Therapy Prevents Airway Dysfunction in a Murine Model of Allergen-Induced Asthma. Lung., v.187, n.2, p.116-27, 2009.

DI VALENTIN, E.; CRAHAY, C.; GARBACKI, N.; HENNUY, B.; GUE’DERS, M.; NOE, A.; FOIDART, J.M.; GROOTEN, J.; COLIGE, A.; PIETTE, J.; CATALDO, D. New asthma biomarkers: lessons from murine models of acute and chronic asthma. Am. J. Physiol. Lung Cell. Mol. Physiol. v. 296, p. L185-L197, 2009. 
DONOVAN, G.M. Modelling airway smooth muscle passive length adaptation via thick filament length distributions. Journal of Theoretical Biology., v. 333, p. 102-108, 2013.

DUVERNELLE, C. Local increase in the number of mast cells and expression of nerve growth factor in the bronchus of asthmatic patients after repeated inhalation of allergen at low-dose Clin. Experim. Allergy., v.31, n. 9, p.1432, 2003.

LIM, R.H.; KOBZIG, L. Sexual Tension in the Airways. Am. J. Respir. Cell. Mol. Biol., v. 38, p. 499-500, 2008.

EL-DESOUKI, N.I.; TABL, G.A.; ELKHODARY, Y.A.; Biological studies on the effect of estrogen on experimentally induced asthma in mice. Toxicol. Ind. Health., v.17, p. 134-138, 2013.

ELIAS, J.A. Airway Remodeling in Asthma., Am. J. Respir. Crit. Care Med., v. 161, p. S168S171, 2000.

ENSOM, E. Estradiol in severe asthma with premenstrual worsening. Ann Pharmacother., v. 37, p. 1610-3, 2003.

ESTAMATIOU, R.; PARASKEVA, E.; PAPAGIANNI, M.; MOLYVDAS, P.A.; HATZIEFTHIMIOU, A. The mitogenic effect of testosterone and $17 \beta$-estradiol on airway smooth muscle cells. Steroids., v. 76, p.400-408 2011.

FARRAJ, A.K.; BOYKIN, E.; LEDBETTER, A.; ANDREWS, D.; GAVETT, S.H. Increased lung resistance after diesel particulate and ozone co-exposure not associated with enhanced lung inflammation in allergic mice. Inhal. Toxicol., v.22, n.1, p.33-41, 2010.

FIRSZT, R.; FRANCISCO, D.; CHURCH, T.D.; THOMAS, J.M.; INGRAM, J.L.; KRAFT, M. Interleukin-13 induces collagen type-1 expression through matrix metalloproteinase-2 and transforming growth factor- $\beta 1$ in airway fibroblasts in asthma. Eur Respir J., v. 16, p. 103-108, 2013

FRANK, T.T. The hormonal causes of premenstrual tension. Arch Neurol Psychiat. v. 26, n. 53, 1931.

FRASOR, J. Profiling of Estrogen up and down regulated gene expression in human breast cancer cells insigths into gene network and pathways underlying estrogenic control of proliferation and cell phenotipe. Endocrinology, v.44, n.10, p.4562-74, 2003.

GALLELLI, L.; BUCETI, M.T.; PALAIA, G. Update on anticytokine treatment for asthma. Biomed. Res. Int., v.104, p. 104-128, 2013.

GALLI, S.; TSAI, M.; PILIPONSKY, A.M. The development of allergic inflammation., Nature., v. 454, n. 24, p. 445-454, 2008. 
GARCIA-ROMAN, J.; IBARRA-SÁNCHEZ, A.; LAMAS, M.; ESPINOSA, C.G. VEGF secretion during hypoxia depends on free radicals-induced Fyn kinase activity in mast cells. Biochem. Biophys. Research Commun., v. 401, p. 262-267, 2010.

GOSEINS, R.; ZAAGSMA, J.; BROMHAAR, M.J.; NELEMANS, A.; MEURS, A. Acetylcholine: a novel regulator of airway smooth muscle remodelling?, European Journal of Pharmacology., v. 500, p. 193-201, 2004.

GINA 2012 Statistics - Global Iniciative for Asthma, 2012. Disponível em: www.ginabrasil.com.br. Acesso em 28.10.2012.

GINA 2013 Statistics - Global Iniciative for Asthma, 2013. Disponível em: www.ginabrasil.com.br. Acesso em 15.06.2013.

GIRASOLE, G. et al. Estrogens prevent the increase of human serum soluble interleukin-6 receptor induced by ovariectomy in vivo and decrease its release in human osteoblastic cells in vitro. Clin. Endocrinol., v. 51, n.6, p.801-7, 1999.

GRÁS, D.; CHANEZ, P.; VACHIER, I.; PETIT, A.; BOURDIN, A.; Bronchial epithelium as a target for innovative treatments in asthma. Pharm. \& Ther., v.7, p. 307-323, 2013.

GUEDES, A. G. et al. Altered airway responsiveness in CD38-deficient mice. Am. J. Respir. Cell. Biol., v. 32, n.2, p.149-56. 2005.

GUEDERS, M.M.; BALBIN, M.; ROCKS, N.; FOIDART, J.M.; GOSSET, P.; LOUIS, R.; SHAPIRO, S.; LOPEZ-OTIN, C.; NOËL, A.; CATALDO, D.D. Matrix metalloproteinase-8 deficiency promotes granulocytic allergen-induced airway inflammation. J Immunol., v. 15, n.175, p. 2589-2597.

GILLIVER, S.C.; EMERSON, E.; ASHCROFT, C. 17- $\beta$ estradiol inhibits wound healing in e mice via estrogen receptor $\alpha$. Am J Pathol., v. 176(6), p. 2707-2721, 2010.

HAAHTELA, T.; LEHTIMAKI, L.; AHONEN, E.; HARJU, E.; JARTTI, T.; KANKAANRANTA, H. KORHONEN, K.; MAKELA, M.; PUURUNEN, M., SOVIJARVI, A.; VALOVIRTA, E.; VENHO, K.K. Duodecim. Update on current care guidelines: asthma. v.129(9), p. 994-995, 2013

HACKEL, P.O.; ZWICK, E.; PRENZEL, N.; ULLRICH, A. Epidermal growth factor receptors: critical mediators of multiple receptor pathways. Curr. Opin. Cell. Biol., v. 11, n.2, p.184-189, 1999. 
HAGE, F.G.; OPARIL, S. Ovarian hormones and vascular disease. Curr Opin Cardiol., v. 28(4), p. 411-416, 2013.

HALWANI, R.; AL-MUHSEN, S.; HAMID, Q. Airway remodeling in asthma., Current Opinion in Pharmacology., v. 10, p. 236-245, 2010.

HAMANO, N.; TERADA, N.; MAESAKO, K.; HOHKI, G.; ITO, T.; YAMASHITA, T.; KONNO. Oxidative stress, chromatin remodeling and gene transcription in inflammation and chronic lung diseases. J. Biochem. Mol. Biol., v. 36(1) p. 95-109, 2003.

HAMID, Q.; TULIC, M. Immunobiology of Asthma. Annu. Rev. Physiol., v. 71, p. 489-507, 2009.

HANTOS, Z.; ADAMICZA, A.; GOVAERTS, E.; DARÓCZY, B. Mechanical impedances of lungs and chest wall in the cats. J. Appl. Physiol., v.73, n.2, p.427-433, 1992.

HASEGAWA, K.; TSUGAWA, Y., BROWN; D.F.M.; CAMARGO, C. A. Childhood Asthma Hospitalizations in the United States, 2000-2009. J. Pediatr., v.7, p.123-133, 2013.

HEISSIG, B.; NISHIDA, C.; TASHIRO, Y.; SATO, Y.; ISHIHARA, M.; OHKI, M.; GRITLI, I, ROSENKVIST, J.; HATTORI, K. Role of neutrophil-derived matrix metalloproteinase9 in tissue regeneration. Histol. Histopathol., v.25, n.6, p.765-70, 2010.

HELLINGS, P. W. Progesterone increases airway eosinophilia and hyper-responsiveness in a murine model of allergic asthma. Clin. Exp. Allergy., v. 33, p.1457-1463, 2003.

HELlingS, P. W . ; KASRAN, A.; LIU, Z.; VANDEKERCKHOVE, P.; WUYTS, A.; OVERBERGH, L.; MATHIEU, C.; CEUPPENS, J.L. Interleukin-17 orchestrates the Granulocyte influx into airways after allergen Inhalation in a mouse model of allergic asthma. Am. J. Respir. Cell Mol. Biol. v. 28, p. 42-50, 2003.

HIRAHARA, K.; POHOLEK, A.; VAHEDI, G.; LAURENCE, A.; KANNO, Y.; MILNER, J.D.; O'SHEA, J.J. Mechanisms underlying helper T-cell plasticity: Implications for immune-mediated disease., J Allergy Clin Immunol., v. 131, n.5, p.1276-1287, 2013.

HIRST, S. T. Airway smooth muscle as a target in asthma. Clin. Exp. Allergy., v.30, n. 1, p. 549, 2000.

HOGG, M. E.; VAVRA, A. K.; BANERJEE, M. N.; MARTINEZ, J.; JIANG, Q.; KEERFER, L. K.; CHAMBON, P.; KIBBE, M. R. The role of estrogen receptor $\alpha$ and $\beta$ in regulating vascular smooth muscle cell proliferation is based on sex. J. Surg. Res., v. 173, p. 1-10, 2012.

HOLGATE, S.T. The role of mast cells and basophils in inflammation. Clin. Exp. Allergy., v. 30, n.1, p. 28-32, 2000. 
HONGZHU, L.; SARATHI, M.; CAO, W.; YANG, G.; LAI, C.; WU, L.; WANG, R. Interaction of hydrogen sulfide and estrogen on the proliferation of vascular smooth muscle cells., Plos one., v. 7, n. 8, p. e41614-e42012, 2012.

HOOVER, W.C.; ZHANG, W.; TEPPER, R.S. Inhibition of p21 Activated Kinase (PAK) Reduces Airway Responsiveness In Vivo and In Vitro in Murine and Human Airways., Plos one., v.7, n.8, p. e42601-e41606, 2012.

HUDGENS, P. W.; MARTORANO, F.; COTTON, E. K. Management of life-threatening asthma with intravenous isoproterenol infusions. Am. J. Dis. Child., v.6, n.130, s.1, p. 39-42, 1976.

ISAAC - International Study of Asthma and Allergies in Childhood. Disponível em: http://www.globalasthmanetwork.org., 2012.

IZUMI, T. Clinical study of idiopathic pulmonary fibrosis. Nippon Naika Gakkai Zasshi., v.10, n.84, s.9, p.1396-406, 1995.

JAMES, A. L.; ELLIOT, J.G.;. JONES, R.L.; CARROLL, M.L.; MAUA, T.; BAI, T.R.; ABRAMSON, M.J.; MCKAY, K.O.; GREEN, F.H. Airway Smooth Muscle Hypertrophy and Hyperplasia in Asthma., Am. J. Respir. Crit. Care Med., v. 185, n. 10, p. 1058-1064, 2012.

JILKA, R.L. Ovariectomy in the mouse downregulateshematopoietic precursors in the bone marrow and their progeny in the peripheral blood : a mediating role of IL-6. J._Bone Min. Res., v. 7, p.115,1992.

JOHNSTON, R.A.; THEMAN, T.A.; LU, F.L.; TERRY, R.D.; WILLIAMS, E.S.; SHORE, S.A. Diet-induced obesity causes innate airway hyperresponsiveness to methacholine and enhances ozone-induced pulmonary inflammation. J. Appl. Physiol., v. 104, n. 6, p. 1727- 1735, 2008.

JONASSON, S.; HEDENSTIERNA, G.; HEDENSTRÖN, H.; HJOBERG, G. Comparisons of effects of intravenous and inhaled methacholine on airway physiology in a murine asthma model.

Respir. Physiol. Neurobiol., v.28, n.165, p. 229-236, 2009 - a.

JONASSON, S.; HJOBERG, J.; HEDENSTIERNA, G.; BASU S. Allergen-induced formation of F2-isoprostanes in a murine asthma model identifies oxidative stress in acute airway inflammation in vivo. Prostaglandins Leukot Essent Fatty acids, v. 80, n.1, p. 1-7, 2009 b.

KABBARA, M. F. Indução de inflamação alérgica pulmonar crônica e persistente em um modelo murino de asma. Monografia de conclusão de curso de Ciências Biológicas e da Saúde da Universidade Presbiteriana Mackenzie, São Paulo, 2007.

KAMINSKA, M.; FOLEY, S.; MAGHNI, K.; STORNESS-BLISS, C.; COXSON, H.; GHEZZO, H.; LEMIE` RE, C.; OLIVENSTEIN, R.; ERNST, P.; HAMID, Q.; MARTIN, J. Airway 
remodeling in subjects with severe asthma with or without chronic persistent airflow obstruction., J. Allergy Clin. Immunol., v.124, p. 45-51, 2009.

KATAGIRI, T. Human metalloprotease/disintegrin-like (MDC) gene: exon-intron organization and alternative splicing. Cytogenet. Cell. Genet., v. 68, n.39, p.1-2, 1994.

KIM M.S.; CHO, K.A.; CHO, Y.J.; WOO, S.Y. Effects of Interleukin-9 Blockade on Chronic Airway Inflammation in Murine Asthma Models. Acta Otolaryngol Suppl., v. 537, p. 27-31, 2013.

KITAZAWA, Y. Stages in the development of the rat lung: morphometric, light and electron microscopic studies. Kaibogaku Zasshi, V.69, n.4, p.392-405, 1994.

KIMBLE , R. B. Persistent bone-sparing effect of interleukin-1 receptor antagonist: a hypothesis on the role of IL-1 in ovariectomy-induced bone loss. Calcif. Tissue Int., v. 55, n.4, p.260-5, 1994.

KNEUER, C. Selectins - Potential pharmacological targets? Drug Discovery Today, v. 11, p. 21-22, 2006.

LABONTÈ, I.; HASSAN, M.; RISSE, P.A.; TSUCHIYA, K.; LAVIOLETTE, M.; LAUZON, A.M.; J.G. MARTIN. The effects of repeated allergen challenge on airway smooth muscle structural and molecular remodeling in a rat model of allergic asthma. Am. J. Physiol. Lung Cell. Mol. Physiol., v. 297, p. L698-L705, 2009.

LAI, H.; ROGERS, D.F. New pharmacotherapy for airway mucus hypersecretion in asthma and COPD: targeting intracellular signaling pathways. J. Aerosol. Med. Pulm. Drug Deliv., v. 23, n.4, p.219-231, d2010.

LAMBRECHT, B. N.; PELEMAN, R.A.; BULLOCK, G. R.; PAUWEL, S.R.A. Sensitization to inhaled antigen by intratracheal instillation of dendritic cells Clinical and Experimental., Allergy., v. 30, p. 214-224, 2000.

LATOURELlE, J.; FABRY, B.; FREDBERG, J.J. Dynamic equilibration of airway smooth muscle contraction during physiological loading., J. Appl. Physiol., v. 92, p. 771-779, 2002.

LEDERLEEN, M.; OZIER, A.; MONTAUDON, M.; BEGUERET, H.; OUSOVA, O.; MARTHAN, R.; BERGER P.; LAURENT, F. Airway remodeling in a mouse asthma model assessed by in-vivo respiratory-gated micro-computed tomography. Eur. Radiol., v. 10, p. 38 $-48,2009$.

LEE, I.T.; YANG, C.M. Inflammatory Signalings Involved in Airway and Pulmonary Diseases. Mediators of Inflammation., v. 2013, p. 1 - 11, 2013. 
LEICK, E.A.; REIS, F.G.; HONORIO-NEVES, F.A.; ALMEIDA-REIS, R.; PRADO C.M.; MARTINS, M.A.; TIBÉRIO, I.F. Effects of repeated stress on distal airway inflammation, remodeling and mechanics in an animal model of chronic airway inflammation. Neuroimmunomodulation., v. 19, n.1, p 1-9, 2012.

LEŚNIEWSKA M. Estrogen receptor beta participate in the regulation of metabolism of extracellular matrix in estrogen alpha negative breast cancer. Folia Histochem Cytobiol. V. 47, n.5, p. 107-12, 2009.

LEUNG, T.F.; KO, F.W.S.; WONG, W.K. Recent advances in asthma biomarker research

Ther. Adv. Resp. Dis., v. 0, p. 1-12, 2013.

LI, W.; TANG, L.; XIONG, Y.; ZHOU, X; WU, L. The chondroprotective effects of dehydroepiandrosterone probably exerted by its conversion to estradiol. J. Ster.Biochem. Mol. Bio., v.134, p. 15-22, 2013.

LIGEIRO DE OLIVEIRA A. P. L; OLIVEIRA-FILHO, R.M.; DA SILVA, Z.L.; BORELLI, P.; TAVARES DE LIMA W. Regulation of allergic lung inflammation in rats: interaction between estradiol and corticosterone. Neuroimmunomodulation., v. 11, p. 20-27, 2004.

LIGEIRO DE OLIVEIRA, A.P.; PERON, J.P.; DAMAZO, A.S.; FRANCO, A.L.; DOMINGOS, H.V.; OLIANI, S.M.; OLIVEIRA-FILHO, R.M.; VARGAFTIG, B.B.; TAVARES-DE-LIMA, W. Female sex hormones mediate the allergic lung reaction by regulating the release of inflammatory mediators and the expression of lung E-selectin in rats. Respiratory Research, 2010.

LIGHT, V.A.; MONTGOMERY, R.D. ; AKINGBEMI, B.T. Sex hormone regulation of collagen concentrations in cranial cruciate ligaments of sexually immature male rabbits. Am J Vet Res., v. 73(8), p. 1186-93, 2012.

LAI, H.; ROGERS, D.F. New pharmacotherapy for airway mucus hypersecretion in asthma and COPD: targeting intracellular signaling pathways. J. Aerosol. Med. Pulm. Drug Deliv., v. 23, n.4, p.219-31, 2010.

MAcKLEROY, W.; Lee, T.H.; Atabai, K. Always cleave up your mess: targeting collagen degradation to treat tissue fibrosis., Am. J.Physiol. Lung Cell. Mol. Physiol.,v.4, p. L709-L721, 2013.

MALIK, R. Gene expression profile of ovalbumin-induced lung inflammation in a murine model of asthma. J. investig. clin. immunol., v. 18, n.2, p. 106-12, 2008.

MANISE, M.; HOLTAPPELS, G.; CROMBRUGGEN, K.V.; SCHLEICH, F.; BACHERT, C.; LOUIS, R. Sputum IgE and Cytokines in Asthma: Relationship with Sputum Cellular Profile., PLoS ONE., v.8, n.3, p. $1-9,2013$. 
MARGULIS, A.; NOCKA, K.H.; BRENNAN, A. M.; DENG, B.; FLEMING, M.; GOLDMAN, S.J.; KASAIAN, M.T. Mast Cell-Dependent Contraction of Human Airway Smooth Muscle CellContaining Collagen Gels: influence of Cytokines, Matrix Metalloproteases, and Serine Proteases., Journal of Immunology, v. 183, p. 1739 -1750, 2009.

MCKAY, S. Tumor necrosis factor-alpha enhances mRNA expression and secretion of interleukin-6 in cultured human airway smooth muscle cells. Am. J. Respir. Cell. Mol. Biol., v.23, n.1, p.103-11, 2000.

McMillan, S. J.; Lloyd, C. M. Prolonged allergen challenge in mice leads to persistent airway remodelling. Clin. Exp. Allergy., v. 34, p. 497-507, 2004.

MEURS, H.; GOSEINS, R.; ZAAGSMA, J. Airway hyperresponsiveness in asthma: lessons from in vitro model systems and animal models. Eur Respir J., v. 32, p. 487-502, 2008.

MILlER, L., HUNT, J.; PLATT, J.S. Hormonal Regulation of Uterine Macrophages. Developmental Immunology., v. 6, p. 105-110, 1998.

MING-XIAO,G.; CHENG, L.; LU, J. Effect of peroxisome proliferator activated receptor gamma on proliferation of airway smooth muscle cells in mice with asthma., Chin. J. Contemp. Pediat., v.15, n. 7, 2013.

MITCHELL, V.L.; WINKLE, L.S.V.; GERSHWIN, L.J. Environmental Tobacco Smoke and Progesterone Alter Lung Inflammation and Mucous Metaplasia in a Mouse Model of Allergic Airway Disease., Clinic. Rev. Allerg. Immunol., v. 43, p.57-68, 2012.

MIYAURA, H.; IWATA, M. Direct and Indirect Inhibition of Th1 Development by Progesterone and Glucocorticoids. J. Immunol., v. 168, p.1087-1094, 2002.

NAUTA, A. J.; ENGELS, F.; KNIPPELS, L.M.; GARSSEN, J.; NIJKAMP, F.P.; REDEGELD, F.A. Mechanisms of allergy and asthma. Eur. J. Pharmacol., v.13, n. 585, p.354-360, 2008.

DE OLIVEIRA A.P.; DOMINGOS, H.V.; CAVRIANI, G.; DAMAZO, A.S.; DOS SANTOS, F.A.L.; OLIANI, S.M.; OLIVEIRA-FILHO, R.M.; VARGAFTIG, B,B.; DE LIMA, W.T. Cellular recruitment and cytokine generation in a rat model of allergic lung inflammation are differentially modulated by progesterone and estradiol, Am J Physiol Cell Physiol. V. 293, n.3, 1120-8, 2007.

DE OLIVEIRA, C.A. Molecular dynamics simulations of metalloproteinases types 2 and 3 reveal differences in the dynamic behavior of the S1' binding pocket. Curr. Pharm. Des., v.13, n.34, p. 3471-5, 2007.

OKAMOTO, T. Molecular mechanism for activation and regulation of matrix metalloproteinases during bacterial infections and respiratory inflammation. Biol. Chem., v.385, n.11, p.997-1006, 2004. 
OPDENAKKER, G.; VAN DEN STEEN, P.E.; DUBOIS, B.; NELISSEN, I.; COILLIE, E.V.; MASURE, S.; PROOST, P.; DAMME, J.V. Gelatinase B functions as regulator and effector in leukocyte biology., J. Leukoc. Biol., v. 69, p. 851-859, 2001.

OVERBEEK, S. A.; BRABER, S.; KOELINK, P.J.; HENRICKS, P.A.J.; MORTAZ, E.; LOTAM, A.T.; JACKSON, P.L.; GARSSEN, J.; WAGENAAR, G.T.M.; TIMENS, W.; KOENDERMAN, L.; BLALOCK, E.J.; KRANEVELD, A.D.; FOLKERTS, G. Cigarette Smoke-Induced Collagen Destruction; Key to Chronic Neutrophilic Airway Inflammation? PLoS One., v.8, n.1, p.e55612, 2013.

PACIFICI, R. Effect of surgical menopause and estrogen replacement on cytokine release from human blood mononuclear cells. Proc. Natl. Acad. Sci. U S A., v. 15, n.88 (12), p.5134-8, 1991.

PARKS, W. C. Matrix metalloproteinases in lung biology. Respir. Res., v. 1, p. 10-9. 2001.

PERA, T.; SAMI, R.; ZAAGSMA, J.; MEURS, H. TAK1 plays a major role in growth factorinduced phenotypic modulation of airway smooth muscle., Am. J. Physiol. Lung Cell. Mol. Physiol., v. 301, p. L822-L828, 2011.

PASCUAL, R.; PETERS, S. P. Airway remodeling contributes to the progressive loss of lung function in asthma: An overview., J. Allergy Clin. Immunol., v.116, p.477-486, 2005.

PAWANKAR, R.; BUNNAQ, C.; KHALTAEV, N.; BOUSQUET, J. Allergic Rhinitis and Its Impact on Asthma in Asia Pacific and the ARIA Update., World Allergy Organ J., v.5(3), p. $\mathrm{S} 212-207,2012$.

PFEILSCHIFTER, J. Changes in proinflammatory cytokine activity after menopause. Endocr. Rev. Feb., v. 23, n. 1, p.90-119, 2002.

PIETRAS, R. J. et al. Interactions between estrogen and growth factor receptors in human breast cancers and the tumor associated vasculature The Breast Journal, v. 9, n. 5, p. 361-73, 2003.

PLUSA, T. Directions of investigation of new drugs in asthma. Pol. Merkur. Lecarski, v. 26(151), p. 5-8, 2009.

GUIDELINES FOR THE DIAGNOSIS AND MANAGEMENT OF ASTHMA - Section 2, Definition, Pathophysiology and Pathogenesis of Asthma and Natural History of Asthma. US Heart, Lung, and Blood Institute. National Institute of Health- US. Full Report 2007.

POWEL, V. Maturational changes in ovine pulmonary vascular responses to inhaled nitric oxide. Pediatr. Pulmonol., v. 27, n.3, p.157-66, 1999.

PREFONTAINE, D.; HAMID, Q. J. Images in allergy and immunology. Allergy Clin. Immunol. , v. 120, p. 1475-1478, 2007a. 
PRÉFONTAINE, D.; HAMID, Q. Airway epithelial cells in asthma., J. Allergy Clin. Immunol. v. 120, n.6, p.1475-1478, 2007 b.

PROSKOCIL, B.J.; SEKHON, H.S.; JIA, Y.; SAVCHENKO, V.; BLAKELY, R.D.; LINDSTROM，J.; SPINDEL， E.R. Acetylcholine is an autocrine or paracrine hormone synthesized and secreted by airway bronchial epithelial cells., Endocrinology., v. 145, n.5, p. 2498-506, 2004.

PROTOCOLO CLÍNICO E DIRETRIZES TERAPÊUTICAS. Ministério da Saúde, Portaria SAS/MS no 709, de 17 de dezembro de 2010.

PUDER, J. J. Estrogen modulates the hypothalamic-pituitary-adrenal and inflammatory cytokine responses to endotoxin in women. J. Clin. Endocrino. Metab., v. 86, n.6, p. 2403-8, 2001.

PUDDICOMBE, S.M.; POLOSA, R.; RICHTER, A.; KRISHNA, M.T.; HORWARTH, P.H.; HOLGATE, S.T.; DAVIES, D.E. Involvement of the epidermal growth factor receptor in epithelial repair in asthma, Faseb J., v.14, p. 1362-1374, 2000.

QIAO, X. Sex steroids and vascular responses in hypertension and aging. Gend. Med., v.5-A, p. 46-64, 2008.

RAHMAN, I. Oxidative Stress, Chromatin Remodeling and Gene Transcription in Inflammation and Chronic Lung Diseases .J. Biochem.Mol. Biol., v. 36 (1), p 95-109, 2003.

RACKÉ, K. MAPK pathway mediates muscarinic receptor-induced human lung fibroblast proliferation. Life Sci., v.30, n. 80(24-25), p.2259-62, 2007.

REAL, F.G.; SVANES, C.; OMENAAS, E.R.; ANTONIO, J.M.; PLANA, E.; JARVIS, D.; JANSON, C.; NEUKIRCH, F.; ZEMP, E.; WJST, M.; SVANES, K.; LEYNAERT, B.; SUNYER, J. Lung function, respiratory symptoms, and the menopausal transition., J allergy Clin Immunol., v. 121, p. 72-80, 2007.

RHODES, L. Sex differences in asthma prevalence and other disease characteristics in eight states. J. Asthma., v.42, n.9, p.777-782, 2005.

RIBOT, C.; TRÉMOLLIÈRES, F.; POUILLÈS, J.M. [Hormone replacement therapy and early and late prevention of postmenopausal osteoporosis., Presse Med., v. 10, n.24, p. 999-1002, 1995. 
RIESENFELD, E.; SULLIVAN, M.J.; THOMPSON-FIGUEROA, J.A.; HAVERKAMP, H.C.; LUNDBLAD, L.K.; BATES, J.H.T.; IRVIN, C.G. Hormone replacement therapy and early and late prevention of postmenopausal osteoporosis. Presse Med. v.10, n.24, p.999-1002, 2010.

RIO, E.M.B.; GALLO, P.R.; SIQUEIRA, A.A.F. Mortalidade por asma no município de São Paulo, Brasil. Rev. Saúde Publ., v.36(2), p. 149-154, 2002,

RIFFO-VASQUEZ,Y.; LIGEIRO DE OLIVEIRA, A.P.; PAGE, C.P.; SPINA, D.; TAVARES DE LIMA, W. Role of sex hormones in allergic inflammation in mice. Clin Exp Allergy, v.37, p. 459-470, 2007.

ROBINSON, D. S. The role of the mast cell in asthma: induction of airway hyperresponsiveness by interaction with smooth muscle? J. Allergy Clin. Immunol., v.114, p.58-65, 2004.

ROCHAT, T. Is intrinsic or non-atopic asthma a particular disease? Rev Med Suisse., v. 16, n.1, p. 2640-2643, 2005.

RODRIGUES-SOARES, C. influência dos hormônios sexuais femininos sobre a inflamação alérgica pulmonar em modelo murino de asma crônica. 2008. $101 \mathrm{f}$. Dissertação (Mestrado em Ciencias) - Instituto de Ciencias Biomédicas, Universidade de São Paulo, São Paulo, 2010.

RUBANYI, G. M. Role of Estrogen receptor in the vascular system. Vascular Pharmacology, v. 38, n. 2, p. 81-88, 2002.

RUBANYI, G. M. Effect of Estrogen on endothelial function and angiogenesis. Vascular Pharmacology, v.38, n. 2, p. 89-98, 2002.

SALLEM, M. L. Mediation of the immunomodulatory effect of beta-estradiol on inflammatory responses by inhibition of recruitment and activation of inflammatory cells and their gene expression of TNF-alpha and IFN-gamma. Int. Arch. Allergy Immunol., v. 121, n.3, p.235-45, 2000.

SALLUSTO, F.; LANZAVECCHIA, A .Exploring pathways for memory T cell generation. J. Clin. Invest., v. 108, p.805-806, 2001.

SCALAN, S. The Dark Side of Urbanization: Growing Incidence of Asthma in Latin America., Disponível em: http://www.un.org/esa/population. Acesso em: 09.08.2010.

SCHOFIELD, M.; CALHOUN, k. Immunology of Allergy., Otolaryngol. Clin. N. Am., v. 44, p. 591-601, 2011.

SCHNAPER, H. W. Sex Steroid and the endothelium Current Medicinal Chemistry, v. 7, $\mathrm{n}$. 5, p.519-31, 2000. 
SCHUligA, M.; HARRIS, T.; STEWART, A.G. Plasminogen activation by airway smooth muscle is regulated by type I collagen. Am. J. Respir. Cell Mol. Biol., v. 44, n.6, p.831$839,2010$.

SCOTTON, C. J.; CHAMBERS, R. C. Molecular targets in pulmonary fibrosis: the myofibroblast in focus. Chest, v. 132, n.4, p. 1311-21, 2007.

SEMENOV, I.; HERLIHY, J.T.; BRENNER, R. In vitro measurements of tracheal constriction using mice., J. Vis. Exp., v. 25, n.64, p. 67-72,2012.

SHALABY, K.H, GOLD, L.G.; SCHUESSLER, T.F.; MARTIN, J.G.; ROBICHAUD, A. Combined forced oscillation and forced expiration measurements in mice for the assessment of airway hyperresponsiveness., Respir. Res., v. 21, p.11-18, 2010.

SHI, Y.H.; SHI, G.C.; YING, W.H.; XIANG-YAN, A.; HAI-XING, Z.; WEI, T.; JIA-YUN, M.; XIAO-YAN, J.; BO-YING, Z. An increased ratio of Th2/Treg cells in patients with moderate to severe asthma., Chin. Med. J., v.126, n. 12, p. 2248-2253, 2013.

SHIFFREN, A., WITT, C.; CHRISTIE, C.; CASTRO, M., Mechanisms of Remodeling in Asthmatic Airways., Journal of Allergy., v. 2012, p. 24-36, 2012.

SHIMIZU, T.; SHIMIZU, S. Azithromycin inhibits mucus hypersecretion from airway epithelial cells., Mediators of Inflammation., v. 2012, p. 265-271, 2012.

SHIMURA, S.; ANDOH, Y.; HARAGUCHI, M.; SHIRATO, K. Continuity of airway goblet cells and intraluminal mucus in the airways of patients with bronchial asthma., Eur. Respir. J., v. 9, n., p.1395-1401, 1996.

SHINAGAWA, K.; KOJIMA, M. Mouse Model of Airway Remodeling. Am. J. Respir. Crit. Care Med. v. 168, p. 959-967, 2003.

SHMUEL, D.I; CORTEZ, Y. Anaphylaxis in dogs and cats. J.Vet. Emerg. Crit. Care., v. 23(4), p. 377-394, 2013.

SILVEIRA, P.S.P.; BUTLER, J.P.; FREDBERG, J.J. Length adaptation of airway smooth muscle: a stochastic model of cytoskeletal dynamics., J. Appl. Physiol., v.99, p. 2087-2098, 2005.

SKOBELOFF, E. The influense of age and sex on asthma admissions. J.A.M.A., v. 268, p.343740, 1992.

SKOBELOFF, E.M.; SATZ, W.A. Estrogen-withdrawl alters bronchial smooth muscle response in the rabbit asthmatic. Ann. Emerg. Med., v.24, p.128, 1996. 
SOARES E.T. $\beta$-Estradiol mediated vessel assembly and stabilization in tumor angiogenesis requires TGF and EGFR crosstalk Angiogenesis., v. 6, n. 4, p. 271-81, 2004.

SPANGLER, A.S. Enhancement of the anti-inflammatory action of hydrocortisone by estrogen. J. Clin. Endocrinol. Metab., v.29, n.5, p. 650-5, 1969.

SPEYER, C. L. Regulatory effects of estrogen on acute lung inflamation in mice. Am. J. Physiol. Cell. Phisiol., v. 288, p. 881-890, 2005.

SPORNITZ, U.M.; SOCIN, C.D.; DRAVID, A.A. Estrous stage determination in rats by means of scanning electron microscopic images of uterine surface epithelium. Anatomy Rec. v. 254, n. $1,1999$.

STRACHAN, D. Ventilatory function in British adults after asthma or wheezing illness at ages 035. Am. J. Respir. Crit. Care Med., v.154, n.6, s. 1, p.1629-35, 1996.

SUGA, M.; IYONAGA, K.; OKAMOTO, T.; GUSHIMA, Y.; MIYAKAWA, H.; AKAIKE, T.; ANDO, M. Characteristic elevation of matrix metalloproteinase activity in idiopathic interstitial pneumonias., Am. J. Respir. Crit. Care Med., v.162, n.5, p.1949-1956, 2000.

SUNDBERG, R.; TORREN, K.; FRANKLIN, A.K.; GISLASON, T.; OMENAAS, E.; SVANES, C.; CHRISTER, J. Asthma in men and women: treatment adherence, anxiety and quality of sleep. Resp. Med., v. 104, p. 337-344, 2010.

SULEK, K. Nobel prize for Edward Calvin Kendall, Thaddeus Reichstein and Philip Showalter Hench in 1950 for their discoveries related to adrenal cortex hormones, their structure and biological activity. Wiad Lek., v.15, n. 21, s.20, p.1885-7, 1968.

SWEDIN, 1.; ELLIS, R.; KEMI, C.; RYRFELDT, A.; INMAN, M.; DAHLÉN, S.E.;

ADNER, M. Comparison of aerosol and intranasal challenge in a mouse model of allergic airway inflammation and hyperresponsiveness., Int. Arch. Allergy Immunol., v.153, n.3, p.249-258, 2010.

TAN, K. S. Premenstrual Asthma. Drugs, v. 61, n. 14, p. 2079-86, 2001.

TAKEDA, M.; TANABE, M.; ITO, W.; UEKI, W.; KONNO, Y.; CHIHARA, M.; ITOGA, M.; KOBAYASHI, Y.; MORITOKI, Y.; KAYABA, H.; CHIHARA, J. Gender difference in allergic airway remodelling and immunoglobulin production in mouse model of asthma. Respirology., $\mathrm{v}$. 18, p. 797-806, 2013.

TAKEYAMA, K.; FAHY, J.V.; NADEL, J.A. Relationship of Epidermal Growth Factor Receptors to Goblet Cell Production in Human Bronchi., Am. J. Respir. Crit. Care Med., v. 163, p. 511-516, 2001. 
TEAL, S.H.; LAI, Y.; HENDERSON JR, W.R.; ALTEMEIER, W.A.; GELB, M.H. Epithelial regulation of eicosanoid production in asthma. Pulm. Pharmacol. Ther., v. 25, p. 432-437, 2012.

TEDder, T. F. et al. The selectins: a vascular adhesión molecules. Faseb Journal, v.9, p. 866873, 1995.

TEGETHOFF, M.; OLSEN, J.; SCHAFFNER, E.; MEINLSCHMIDT, G. Asthma During Pregnancy and Clinical Outcomes in Offspring: A National Cohort Study., Pediatrics., v.132, n. 3, p. 1-10, 2013.

TELLES-FILHO, P. A. Incidência da asma bronquica no Brasil. Revista Brasileira de Medicina. v.7, n3, 2007.

TELLES-FILHO, P.A. Asma brônquica. Disponível em: http://www.asmabronquica.com.br. Acesso em: 17.03.2013.

TEMANN, U.A.; PRASAD, B.; GALlUP, M.W.; BASBAUM, C.; HO, S.B.; FlaVELL, R.A.; RANKIN, J.A., A novel role for murine IL-4 in vivo: induction of MUC5AC gene expression and mucin hypersecretion., Am. J. Respir. Cell Mol. Biol., v. 16, n.4, p.471-478, 2007.

TOMIOKA, S.; BATES, J.H.; IRVIN, C.G. Airway and tissue mechanics in a murine model of asthma: alveolar capsule vs. forced oscillations., J. Appl. Physiol., v. 93, n.1, p. 263-270, 2002.

TORRÈN, K.; HERMANSSON, B.A. Incidence rate of adult-onset asthma in relation to age, sex, atopy and smoking: a Swedish population-based study of 15813 adults. Int. J. Tuberc. Lung Dis., v. 3, n.3, p. 192-7, 1999.

TOYOSHIMA, M.T.; ITO, G.M.; GOUVEIA, M.; Trends in morbidity for respiratory diseases among hospitalized patients in the city of São Paulo. Rev. Assoc. Med. Bras., v. 51, n.4, p. 209213, 2005.

TROISI, R.J. Menopause, postmenopausal estrogen preparations, and the risk of adult onset asthma. A prospective cohort study. Am. J. Respir. Crit. Care Med., v. 152, p. 1183-8, 1995.

TURNER, B.B. Sex difference in glucocorticoid binding in rat pituitary is estrogen dependent Life Sci. v.46(19), p.1399-1406, 1990.

UEHARA, A. Three-dimensional analysis of blood vessels in bronchioloalveolar carcinoma. Lung, v.182, n.6, p. 343-53, 2004.

VEERAPPAN, A.; O'CONNOR N.J.; BRAZIN, J.; REID, A.C.; JUNG, A.; MCGEE, D.; SU.MMERS, B.; BRANCH-ELLIMAN, D.; STILES, B.; WORGALL, S.; KANER 
R.J.; SILVER, R.B. Mast cells: a pivotal role in pulmonary fibrosis., DNA Cell Biol., v.32, n. 4, p. 206-18, 2013.

VERMAELEN, K.Y.; CARRO-MUINO, I.; LAMBRECHT, B.N.; PAUWELS, R.A. Specific Migratory Dendritic Cells Rapidly Transport Antigen from the Airways to the Thoracic Lymph Nodes., J. Exp. Med., v. 193, n. 1, p. 51-60, 2001.

VAN DER VLIET, A. nox enzymes in allergic airway inflammation., Biochim. Biophys. Acta., v. 1810, n. 11, p. 1035-1044, 2011.

VANDOOREN, J.; VAN DEN STEEN, P.E.; OPDENAKKER, G. Biochemistry and molecular biology of gelatinase B or matrix metalloproteinase-9 (MMP-9): the next decade. Crit. Rev. Biochem. Mol. Biol. v.48, n.3, p.222-72, 2013.

VERTHELYI, D.; KLINMAN, D.M. Sex hormone levels correlate with the activity of cytokinesecreting cells in vivo. Immunology, v. 100, n.3, p.384-90, 2000.

VIGNOLA, A.M.; CHANEZ, P.; CHIAPPARA, G.; MERENDINO, A.; PACE, E.; RIZZO, A.; LA ROCCA, A.M.; BELLIA, V.; BONSIGNORE, G.; BOUSQUET, J. Transforming growth factor-beta expression in mucosal biopsies in asthma and chronic bronchitis., Am. J. Respir. Crit. Care Med. v.156, n.2, p. 591-599, 1997.

VINA, J.; GAMBINI, J.; LOPEZ-GRUESO, R.; ABDELAZIZ, K.M.; JOVE, M.; BORRAS, C. Females live longer than males: role of oxidative stress., Curr. Pharm. Des., v.1, n.17, p. 3959$65,2011$.

VRIEZE, A.; KERSTJENS, H A. M. Perimenstrual asthma: a syndrome without known cause or cure. J. of Allerg. Clin. Immunol., v. 112, p. 271-82, 2003.

WANG, Y.; Cela, E.; Gagnon, S.; Sweezey, N.B. Estrogen aggravates inflammation in Pseudomonas aeruginosa pneumonia in cystic fibrosis mice. Respiratory Research., v. 11, p. $166,2013$.

WARD, N. S.; DUSHAY, K.M. Clinical concise review: Mechanical ventilation of patients with chronic obstructive pulmonary disease. Crit. Care Med., v. 36, n.5, p. 1614-9, 2008.

WATSON, L.; FLORIAN, T.; PHILIP, J.; HOLGATE, S.T. et al., Factors associated with mortality after an asthma admission: A national United Kingdom database analysis. Respiratory Medicine., v. 101, p. 1659-1664, 2007.

WHITE, R. E. Estrogen and vascular function. Vasc. Pharmacol., v.38, n. 2, p. 73-80, 2001.

WOLFF, P. L. A histochemical study of immune destruction of the lymphopoietic system. Experientia, v.15, n.23, s.12, p. 1012-3, 1967. 
WOLTERING, R.G.J.; HENDRICKS, R.W. Type 2 Innate Lymphocytes in Allergic Airway Inflammation., Curr. Allergy Asthma Rep., v. 13, p.271-280, 2013.

YANG, G.; VOLK, A,; PETLEY, T.; EMMELL, E.; GILES KOMAR, J.; SHANG, J.L.; DAS, A.D.; SHEALY, D.; GRISWOLD, D.E.; LI, L. Anti-IL-13 monoclonal antibody inhibits airway hyperresponsiveness, inflammation and airway remodeling. Cytokine., v. 28, p. 224-232, 2004.

YANG, C. M.; HSIEH, H. L.; LEE C. W. Intracellular signaling mechanisms underlying the expression of proinflammatory mediators in airway diseases Chang Gung Med. J., v. 28, n.12, p. 813-23, 2005.

YAZDANBAKHSH, M; KREMSNER, P.G.; VAN REE, R. Allergy, parasites, and the hygiene hypothesis., Science., v. 19, n. 296, p. 490-494, 2002.

YING, S.; ZHANG, G.; GU, S.; ZHAO, J. How much do we know about atopic asthma: where are we now? Cell. and Mol. Immunol., v. 3, n. 5, p. 321-31, 2006.

YOO, D.; GUKB, K.; KIMA, H.; KHANGB, G.; WUA, D.; LEEA, D. Antioxidant polymeric nanoparticles as novel therapeutics for airway inflammatory diseases. International Journal of Pharmaceutics., v.450, p. 87- 94, 2013.

YUERTA-YEPEZ, S.; BAAY-GUZMAN, G.J.; GARCIA-ZEPEDA, R.; HERNANDEZPANDO, R.; VEJA, M.I.; GONZALEZ-BONILLA, C.; BONAVIDA,B 2-Methoxyestradiol (2$\mathrm{ME})$ reduces the airway inflammation and remodeling in an experimental mouse model. Clin Immunol, v. 129, p. 313-324, 2008.

ZHAO, J.; IMBRIE, G.A.; BAUR, W.E.; YIER, L.K.; ARONOVITZ, M.J.; HASELMANN, G.M.; LU, Q.; KARAS, R.H. Estrogen receptor-mediated regulation of microRNA inhibits proliferation of vascular smooth muscle cells. Arterioscler Thromb Vasc Biol., v. 33(2), p. $257-265,2013$.

ZHAO, Y.; KOGAR, K.; OSUGA, Y.; IZUMI, G.;TAKAMURA, M.; HARADA, M.;HIRADA, T.; HIRODA, Y.; YOSHINO, I.; INOUE, S.; FUJII, T.; KOZUMA, S. Cyclic Stretch Augments Production of Neutrophil Chemokines and Matrix Metalloproteinases-1 (MMP-1) from Human Decidual Cells, and the Production was Reduced by Progesterone. Am. J. Reprod. Immunol., v. 69, p.454-462, 2013.

YU, Z.H.; XU, J.R.; WANG, Y.X.; XU, G.N.; WU, D.Z.; CUI, Y.Y.; CHEN, H.Z. Targeted Inhibition of KCa3.1 Channel Attenuates Airway Inflammation and Remodeling in Allergic Asthma. Am. J. Respir. Cell. Mol. Biol., v. 48, n. 6, p. 685-693, 2013. 